This dissertation has been microfilmed exactly as received

Mic $60-4084$

GEBHART, Jamos Warren. THE IEACHING OF SCLENCE IN THE SLCONDARY SCHOOLS OF MIONTANA.

The Ohio State University, Ph. D., 1960 Education, general

University Microfilms, Inc., Ann Arbor, Michigan 


\section{THE TEACHING OF SCIENCE IN THE SECONDARY SCHOOLS OF MONTANA}

\section{DISSERTATION}

Presented in Partial Fulfillment of the Requirements for the Degree Doctor of Philosophy in the Graduate School of The Ohio State University

\section{By}

JAMES WARREN GEBHART, B. S., M。S.

The Ohio State University 1960

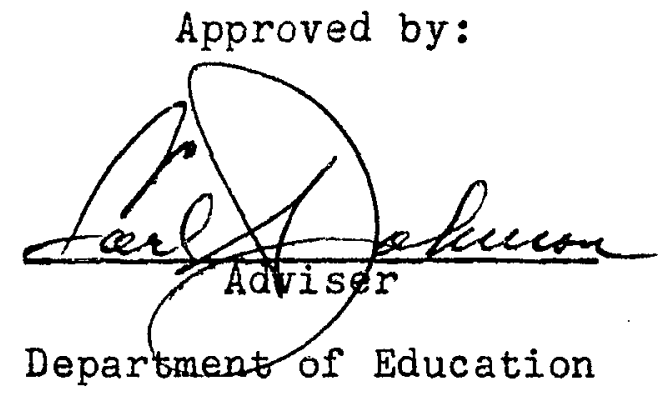


ACKNOWLEDGMENTS

For the inspiration, encouragement, tolerance, and help in the production of a major work one is indebted to many individuals, but I should like to pay special tribute to those without whose help this dissertation might never have been written.

To my first adviser, Dr. Guybert P. Cahoon, who saw me through the early years of this program, and to Dr. Carl S. Johnson, who took over when Dr. Cahoon could no Ionger carry on, I am especially grateful. To Dr. Roscoe Ho Eckelberry and Dr. Norman F. Woelfel for their continued help and inspiration, and to Dr. Charles A. Dambach and Dr. George L. Lewis for their patience and forbearance in reading and helping correct the early drafts of the manuscript, and finally to my wife, varion, who did much of the editing and all of the typing, I am most thankful. 
TABLE OF CONTENTS

CHAPTER

PAGE

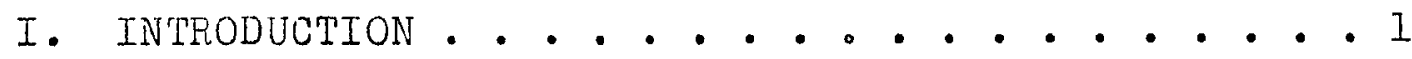

II. MONTANA CONDITIONS PERTINENT TO THE STUDY. • . II

Location and Size. . . . . . . . . 11

Topography and Climatic Factors. . . . . 12

Geographic Isolation . . . . . . . 15

School Laws Pertinent to the Study . . . . 16

School Finance........... 20

Summary. . . . . . . . . . . 28

III. CURRICULA AND ENROLLMENT • • • . • • • • • 30

School Enrollment. . . . . . . . 30

Studies on Enrollment. . . . . . . 33

Size of Montana's High Schools . . . . . 38

Distribution of Science Teachers . . . . . 44

Distribution of Science Courses. . . . . 48

Chemistry and Physics Available to

Montana Pupils.......... . 53

Teaching Assignments . . . . . . . 56

Science Teachers in Small Schools Teach

IVore Non-Science Subjects. . . . . . 61

Non-Science Subjects Taught by Science

Teachers .......... 63 
C HAPTER

PAGE

Summary . • • . • • • • • • • 66

IV. PREPARATION OF SCIENCE TEACHERS IN MONTANA • • 70

Teachers and Quality of Instruction. . . . 70

What Wakes a Good Teacher? . . . . . . 75

Sources and Procedures . . . . . . . 77

General Science Teachers . . . . . . . 81

Biology background of general science

teachers... . . . . . . . . 81

Chemistry background . . . . . . . 83

Physics background . . . . . . . . 85

Geology background . . . . . . . . 88

Total science background . . . . . . . 91

Biology Teachers . . . . . . . . . . 94

Biology background of biology teachers . . 94

Chemistry background . . . . . . . . 96

Physics background . . . . . . . . . 98

Geology background . . . . . . . . 100

Total science background . . . . . . 102

Chemistry Teachers . . . . . . . . 105

Chemistry background of chemistry teachers . 105

Biology background . . . . . . . . 106

Physics background . . . . . . . . . 109

Geology background . . . . . . . . . 111

Total science background . . . . . . . 113 
Physics Teachers . . . . . . . . . 115

Physics background of physics teachers . . 115

Biology background . . . . . . . . . 119

Chemistry background . . . . . . . . 121

Geology background . . . . . . . . 123

Total science background . . . . . . . 125

Astronomy in Background of Science Teachers. 127

Other Pertinent Research . . . . . . . 129

Comparing the Science 'Teachers of irontana,

Ohio, and Wisconsin. . . . . . . . 131

Teacher Turnover . . . . . . . . . . 138

Science Teachers' Salaries . . . . . . 140

Profile of the Montana Science Teacher . . . 143

V. CONCLUSTONS AND RECOMVENDATIONS. . . •. . . 145

Small High Schools . . . . . . . . . 146

Number of School Districts Should Be Reduced . 148

Interim Measures . . . . . . . . . . 152

Curriculum Can Be Improved . . . . . . . 153

A National Science Curriculum Center . . . 155

Resource Units . . . . . . . . . 156

Content Needs Revision . . . . . . . . 159

The jurior High School . . . . . . . . 163

Teacher Preparation. . . . . . . . . 164

Certification Requirements . . . . . . . 166 
CHAPTER

Science Courses Specifically for Teachers. . 170 Five-Year Training Program Desirable . • . . 171 Summer Offerings for Science Teachers. • . . 172 Graduate-Level Offerings . . . . . . . 173 Salaries Need Improvement. . . . . . . . 175 APPENDIX A: FORN A REPORT . . . . . . . . . 176 APPENDIX B: SAMPLE CURRICULA FOR THE PREPARATION OF HIGH SCHOOL SCIENCE TEACHERS, TAKEN FRONI REPORT NO. 5 OF THE AAAS COOPARATIVE COMMITTEE. . . . . . . 181 BIBLIOGRAPHY . . • . . . . . . . . . . . 191 AUTOBIOGRAPHY. • • • . . • • • • • • • . • 197 
vii

\section{LIST OF TABLES}

TABLE

PAGE

1. Per Capita General Revenue of State and

Local Governments. . . . . . . . . 22

2. General Revenue per \$1,000 of Personal

Income . . . . . . . . . . . 24

3. Sources of Revenue for Montana Schools . . . 26

4. General Expenditure of State and Local

Governments, by Function . . . . . . 27

5. Number and Percentages of Public secondary

Schools in Montana in Each Size Interval . 39

6. A Comparison of Three Studies of Enrollment. . 4 I

7. Number of Pupils Enrolled in Nontana Fublic

High Schools in 1958-59. . . . . . . . 45

8. Distribution of Teachers of Science. . . . . 47

9. Number and Per Cent of Wontana High Schools

Teaching Four irain Sciences. . . . . . 49

10. Number of Hontana High Schools Teaching

Chemistry and Physics in 1957-58. . . . . 51

11. Number of Pupils Enrolled in All Secondary

Science Classes, 7-12. . . . . . . . 54

12. Number of Teachers Teaching Full Time in

One Science Subject. . . . . . . . 57

13. Distribution of One-Subject Science

Teachers, by School Size . . . . . . 59 
viii

TABLE

PAGE

14. Distribution of Science Teachers Teaching More Than One Science Subject. . . . . 60

15. Distribution of Science and Non-Science

Classes............ 62

16. Numbers of Classes in Non-Science Subjects . 64

17. Credits Earned in Biology by General Science

Teachers ........... 82

18. Credits Earned in Chemistry. ....... 84

19. Credits Earned in Physics. . . . . . . 86

20. Credits Earned in Geology. . . . . . . . 90

21. Total Science Credits Earned by General

Science Teachers . . . . . . . 92

22. Number of Science Areas in Which General

Science Teachers Received Credit . . . . 93

23. Credits Earned in Biology by Biology

Teachers . . . . . . . . . 95

24. Credits Earned in Chemistry. . . . . . . 97

25. Credits Earned in Physics. . . . . . . 99

26. Credits Earned in Geology. . . . . . . . 101

27. Total Science Credits Earned by Biology

Teachers . . . . . . . . . 103

29. Number of Science Areas in Which Biology

Teachers Received Credit ....... 104 
29. Credits Earned in Chemistry by Chemistry

Teachers . . . . . . . . . . 107

30. Credits Earned in Biology. . . . . . . . 108

31. Credits Earned in Physics. . . . . . . 110

32. Credits Earned in Geology . . . . . . . 112

33. Total Science Credits Larned by Chemistry

Teachers . . . . . . . . . . 114

34. Number of Science Areas in Which Chemistry

Teachers Received Credit . . . . . . 116

35. Credits Earned in Physics by Physics

Teachers . . . . . . . . . . . 118

36. Credits Earned in Biology . . . . . . . 120

37. Credits Earned in Chemistry. . . . . . . . 122

38. Credits Earned in Geology. . . . . . . . 124

39. Total Science Credits Earned by Physics

Teachers . . . . . . . . . . 126

40. Number of Science Areas in Which Physics

Teachers Received Credit . . . . . . . 128

41. Comparison of the Preparation of General

Science Teachers in liontana, Ohio, and

Wisconsin. . . . . . . . . . . . 133

42. Comparison of Biology Teachers . . . . . 134

43. Comparison of Chemistry Teachers . . . . . 136

44. Comparison of Physics Teachers . . . . . . 137 
TABLE

45. Total Years Taught and Number of Years

in Present School System . . . . . . 139

46. Salary Range by School Size Categories . . . 142

47. Number of School Districts in Selected

Western States......... . 149

48. Certification Requirements for Science

Teachers in Fifteen States . . . . . 168 


\section{LIST OF FIGURES}

FIGURE

PAGE

I. Relative Numbers of Public High Schools

in Various Enrollment Categories, Montana

and the Nation .......... 43

II. Pupils Enrolled Compared with Numbers of

ivontana Public High Schools. . . . . . 46

III. Salaries of Full-Time Secondary Science

Teachers in Montana. . . . . ... . 141 
CHAPTER I

\section{INTRODUCTION}

How well are we educating our young people to deal with the problems of the scientific age in which we live? This is a difficult question for any people to answer. It is especially difficult for us in the United States, for we are confused by widely publicized and conflicting philosophies and badgered by many organized pressure groups. Education within a democracy is a very complicated process. Because it is a function of such a society, it is not centrall: controlled, nor does it lend itself readily to the establishment of standardized curricula. It is extremely varied and subject to continuous experimentation, and it generally reflects rather than leads the thinking of communities. In this country it is legally under the control of the states, but in practice it is controlled largely at the local level.

Sletten, in an unpublished paper, pointed up the relationship between the local school boards and the states, as follows:

State constitutions and court decisions have consistently held that: 
1. There exists the supremacy in school matters of state regulation over city and home rule charter.

2. All school board members, no matter how appointed or elected, are agents of the state.

3. The responsibility of local school officers is directed to all the people of the state rather than just to the people of the locality.

4. The state legalization of school districts gives the district only the powers to carry on certain functions delegated to them by the state. The local school district has no inherent rights. The state legislature in most states (Constitutional limitations exist in a few) may at any time alter district boundaries, increase or restrict delegated district authority, or eliminate the districts entirely. 1

Local control is particularly significant in Montana, but it is difficult to isolate the specific factors which have blocked attempts to consolidate powers now exercised by local boards. Some of these factors are the provincialism of rural communities, lack of understanding of the problems of education, ignorance of the financial structure of the state's educational system, subjective community loyalties, and a state legislature controlled by rural representation. These facts make it very difficult for our educational system to meet an emergency, when such an emergency requires at least some degree of strongly

\footnotetext{
$I_{\text {Vernon Sletten, "Some Aspects of Montana School }}$ District Reorganization and Examples," unpublished paper,
} Montana State University, 1959. 
centralized control.

Today we face a real emergency, which exists partly because the strongly centralized educational system of an unfriendly power is geared to a technology than can produce weapons designed for total destruction. The political philosophy of that country indicates that the system was set up for aggressive rather than f'or defensive purposes, and history suggests that when the odds seem favorable, aggressive action could begin. Recent figures released by government experts show that such action could result in the destruction of 135 million Americans and a regression of civilization to the level of the Middle Ages.

Another danger to our democratic society, less obvious but nonetheless real, lies in the area of economic development. Our competitor's tight educational system, organized to train scientific and technological personnel, is one of the reasons why we are being challenged in the field of industrial development. Should the existing trend continue in Iron Curtain countries, Bamboo Curtain countries, or any other countries that are out to destroy us by one means or another, we shall find our economic existence threatened in a very few years. It may well be that the real danger lies here rather than in the area of armament production. If we can be misled to the extent that much of our scientific manpower is directed toward producing equip- 
ment for a war which may never occur, our political competitors can direct their potential to producing equipment which may ultimately bring about our economic destruction. We are faced with an emergency, probably the most serious one since this country became a nation. It is an emergency more closely tied in with our educational system than any previous one. It challenges our program for training scientists in particular. Statistics indicate that we are falling behind in the number of scientists, engineers, and technicians. E. S. Obourn, Specialist for Science in the Office of Education, Department of Health, Education, and Welfare, in an address to the National Association for Research in Science Teaching, April 21, 1956 , said:

Whether we are aware of it or not, we as professional science educators are, together with our colleagues in the colleges and universities, engaged in a competition of survival with our counterparts in the Iron Curtain countries. . . If our way of life is to survive, it will be largely the result of the fact that we have won the battle in our classrooms and our laboratories. Judging only on the basis of numbers, our present position in the race is not an enviable one. In 1950, in the U.S.S.R. 28,000 engineers were graduated. Last year this number was increased to over 50,000. Over the same period the Soviets have also made percentage gains in trained research personnel and in industrial technologists. Do the figures show a similar gain in America? In fact over the same five-year period our production of engineers has declined from 53,000 in 1950 to 23,000 in 1955. . . Recently the U.S. Manpower Commission estimated that there were 7,500 positions vacant requiring research 
scientists and more than 15,000 unmanned engineering
jobs. Fitzpatrick of Columbia, discussing the scientific manpower situation, says:

To summarize the teacher situation, it seems safe to conclude that the supply of scientific personnel in the U.S. tends to dry up at its secondary source because of a shortage of competent teachers and concomitantly because of a lack of an adequate and dynamic secondary school program of science and mathematics. 3

It is not alone to meet emergencies such as that described above that we need to take a look at that part of our educational system designed to produce scientifically literate citizens. It stands to reason that we cannot do the whole job simply by strengthening that phase of the program which is designed to prepare young people for college. We must also re-examine the secondary science program offered those students whose formal education will terminate with a high school diploma. Adults must be given sufficient background to help them make sound value judgments, to help them make wise decisions when called upon to vote or otherwise participate in projects requiring some fundamental knowledge of science. One area which will more

2 Ellsworth S, Obourn, "The Role of the Professional Science Educator in the Present Manpower Shortage," Science Education, XIII, No. 2 (March, 1957), 134 .

${ }^{3}$ L. P. Fitzpatrick, "The Scientific Manpower Problem and the Program of Teachers' College, Columbia University," Science Education, XLII, No. 2 (March, 1957), 143. 
and more demand an educated citizenry is that of natural resource management. Mass communication media and their accompanying commercialism also require fundamental scientific knowledge if we are to protect ourselves from questionable advertising which disregards or distorts scientific facts in its effort to make money for the manufacturer. If present advertising practices are permitted to continue, we have a definite responsibility for educating our people to help them decide between fact and hokum. So much is done today under the name of science that we need, among other things, to understand the limitations of science as well as its potentialities. These educational responsibilities need immediate action, for there are dangers here as potent as those which threaten us from outside sources.

For several years we have been bombarded with articles and books on the seriousness of the situation in science education and on the shortcomings of our educational system in general. These publications have doubtless achieved a purpose: they have encouraged research, which in turn has helped shift the attack on the problem fruin a subjective and emotional level to a more scientific and objective one.

Purpose and Method of This Study

The foregoing comments have been presented to show 
the need for a critical examination of our science-education program. The area of science education was chosen because of the unusual significance that science has assumed at the present time. The purpose of this research was to accumulate and interpret information in regard to science teaching in the secondary schools of Montana and to utilize this information to make suggestions for improving the science education program both in Montana and in the nation. Although a number of such studies have already been made, no pattern of attack has yet been standardized. The study of Montana's science-education program has drawn upon procedures used in several other researcines. In general, the study covers three broad areas--the schools, the science curriculum, and the science teacher; and it is in these three areas that recommendations will be made. Because the topography, climate, and economic structure of Montana are basic factors in shaping its educational system, a chapter is included to present pertinent information on these topics. Many of Montana's educational problems are rooted in the geographical features and the natural-resource economy of the state: c.g., valley provincialism, an economy based largely on primary industries, and extensive federal holdings. This background is the subject of Chapter II.

Chapter III will provide an analysis of Montana 
secondary school enrollment statistics as they are related to secondary science: the number and size of the secondary schools, the number of teachers teaching science, the teaching assignments of science teachers, and the kind and number of science classes that are offered.

Chapter IV, utilizing college transcripts, tabulates and discusses the preparation of Montana-trained teachers now teaching general science, biology, chemistry, and physics, and their training in the fields of biology, chemistry, physics, and geology (or earth science). A profile of the Montana science teacher will be presented in the last part of this chapter. Specifically, it will show his major and minor preparation for teaching, his teaching assignment, the degrees he holds, how long he has taught, how long he has been in the system in which he was employed in 1958-59, in what size school he teaches, and the salary he was receiving in $1958-59$.

The findings will be summarized in the last chapter, and changes will be recommended regarding science teaching both in Montana and in the nation. Recommendations will be offered concerning optimum school size and steps that might be taken to achieve this optimum size, concerning the science curricula of secondary schools, and concerning teacher preparation. Finally, consideration will be given to the question of how much can be accomplished without violating 
the philosophy which governs the organization and operation of the American school.

All statistical information, unless otherwise stated, is for the 1958-59 school year. Form A reports (see Appen$\operatorname{dix}$ A), sent to the Department of Public Instruction of the state of Montana by all secondary schools in the state, were used to secure the data for enrollment, classes taught, class sizes, and teaching schedules. General enrollment statistics were obtained from the Montana Educational Directory, a publication distributed by the Department of Public Instruction each December, and containing, among other things, enrollment statistics collected during the current school year.

The transcripts which provided most of the data for Chapter IV were obtained from the various units, colleges or university, of the greater University of Montana from which the teachers graduated (Montana's state institutions of higher education are units of the University of Montana). Two hundred and five of these transcripts were obtained and processed. Other items of information about teachers, such as number of years taught, salaries, and degrees held, were obtained from the Form A reports.

Statistical information on such topics as school enrollment, number of school districts, and certification of teachers has been introduced into the study, and the stat- 
Istics are compared with those of two similar studies, made in Ohio and Wisconsin. These statistics help to show how Montana compares with schools in other states, and they provide the basis for such generalizations as comparative statistical information seems to warrant.

One term used throughout the study needs clarification: the phrase "secondary school." In Montana, secondary schools sometimes include the seventh and eighth grades. Teachers certified to teach in secondary schools may legally be assigned to the seventh and/or eighth grade.' Those Montana schools where seventh, eighth, and ninth grades have been combined to form junior high schools have been included in the statistical information related to secondary schools. When it has become necessary for purposes of comparison to secure information for grades nine through twelve, ninth grade statistics have been separated from junior-high figures so that comparable information could be used. 
CHAPTER II

MONTANA CONDITIONS PERTINENT TO THE STUDY

To understand the educational problems of Nontana, one needs to study the physical environment, since both the economy of the state and the activities of its people are so closely related to it.

Location and Size

Montana lies between $44^{\circ}$ and $49^{\circ}$ north latitude and between $104^{\circ}$ and $116^{\circ}$ west longitude. It is our fourth largest state, encompassing an area of 147,138 square miles; its land area is greater than that of the combined New England states plus New York, New Jersey, Niaryland, and Delaware. It is more than three times as large as Pennsylvania. From east to west it extends 550 miles, and from north to south 325 miles. One county alone (Beaverhead) is larger than the state of Connecticut.

There are fifty-six counties and a small portion of Yellowstone Park within the state. The civil divisions of the counties include school districts, civil townships, and election precincts. Incoroorated cities and towns form subdivisions of the civil divisions in which they are located. In several instances school districts spread into 
more than a single county. Of the total area of Montana, 28 per cent or $33,579,131$ acres $(52,467$ square miles) were owned, held in trust, or leased by the federal government in 1950.

\section{Topography and Climatic Factors}

The western third of the state is traversed by more than twenty-five generally parallel mountain ranges that run in a northwest-southeast direction. These are part of the greater Rocky Mountains, which are wider in Iontana and Idaho than in the area to the south. In the intermountain valleys and basins, which vary from ten to twenty miles in width and from twenty-five to one hundred miles in length, are located the villages and cities.

The continental divide separates the state into two unequal parts. Seven major mountain passes control the east-west transportation routes across the divide. The Missouri-Mississippi River drainage begins on the eastern slopes of the divide, while the drainage to the west is through tributaries of the Columbia. In the north a small area drains to Hudson Bay by way of the Belly River.

The eastern two-thirds of the state is part of the Great Plains, broken by seven isolated mountain areas. The plains begin in the bench lands along the eastern slopes of the divide at an elevation of about 3500 feet 
above sea level and extend eastward beyond the borders of the state. In the northeast, along the Missouri River, the elevation drops to 1900 feet.

The highest elevation in the state is Granite Peak $(12,850$ feet) in Park County near the south-central border, and the lowest elevation is 1800 feet in the northwest, where the Kootenai River leaves the state. The average elevation is 3400 feet, the lowest mean elevation of any Rocky Mountain state; however, appreciable portions of western Montana lie at elevations of more than 5000 feet.

Because the high mountain ranges in the western third of the state lie at right angles to the prevailing westerlies and block the flow of winds, much of their moisture is removed before they reach Montana. Hence the rainfall is scant over much of the state. As a result, dry farming or irrigation is necessary for growing crops. Large ranches for stock-raising are also important in the state's farm economy, Other major sources of income include mining, commercial lumbering and wood products industries, and the tourist trade.

Average rainfall for the state is about 15 inches, with the highest average of 18 inches in the western part. Temperatures and rainfall vary with elevation, the higher portions being both colder and wetter. Because of these climatic differences the mountainous western part of the 
state is largely covered with forests. Much of this area is in national and state forests, and it is from the latter that the schools of the state get a significant portion of their operating funds.

The differential heating effect of the sun's rays is very noticeable in Montana, which is located in the interior of the continent. Because land areas heat up and cool off about five times as fast as water, the annual range of temperature is greater than that of coastal. regions. Summer daytime temperatures and winter lows are extreme: at present Montana holds the record low temperature for the United States, excluding Alaska.

Winter snows are not unusually deep but are generally low in moisture content and hence are easily moved by wind. East of the divide, where the southward sweep of polar continental air masses is unchecked, ground blizzards are frequent during the winter months. Driving may be very difficult and hazardous because of drifted highways and low visibility. And, although Montana's main highways are paved and passable throughout the year, side roads are generally unimproved; during spring thaws and winter storms these side roads either are blocked or are extremely hazardous for travel. Major mountain passes are kept open to traffic all year round except in extreme emergencies, but those passes not on main highways are often closed from 
October or November to the following May.

\section{Geographic Isolation}

These conditions all combine to make pupil transportation a major problem in Montana. Some elementary schools in isolated areas are closed entirely during part of the winter and remain open during much of the summer instead, and some secondary pupils either must travel considerable distances to school or must board in towns during the school week.

Isolation as a deterrent to consolidation of many of Montana's small high schools, although a factor, is not as important a factor as is sometimes believed by those who oppose consolidation. Statistical information regarding school size and average mileage distances from other high schools is reported in the January, 1959, issue of the Research Record. This report shows that:

Over fifty percent of Montana high schools are within fifteen miles of another high school. . . 19 of the 34 high schools enrolling 40 or less pupils are within 15 miles of another high school. . 。 Nearly 70 percent of high schools with enrollments of 41-75 pupils are within fifteen miles of another high school. . . 22 of 46 high schools of enrollments of 76-150 pupils are within this 15-mile distance of another high school. 4

$4 "$ A Study of Montana Curricular Offerings Related to Distance Factors," Research Record, V, No. 3-4 (January, 1959), 5-6. 
However, these climatic, topographic, and distance factors, along with local prejudices, do make consolidation of the many small schools into larger, more efficient ones very difficult at present. The implications of these factors will be discussed in more detail in succeeding chapters.

School Laws Pertinent to the Study

Since there is a relationship between the size of the school and the efficiency of its operation, and since this very materially affects the science education program, that portion of the Montana school laws which deals with school size is included in this chapter. High schools in Montana are defined in the school laws as:

A high school is a public school as defined in the general school laws and is an integral unit of the public school system which comprises some one or more of the grades of school work intermediate between the elementary schools and the institutions of higher education of the state of Montana, and which has its own administrative head and corps of teachers under the direct supervision either of a district superintendent and the board of trustees of a school district, or of a county high school principal and board of trustees of such county high school, as the case may be.

Types of public high schools are defined and designated as follows:

1. A junior high school is a public school as defined in the general school laws and is an integral unit of the public school system which comprises what is ordinarily designated 
as the work of the seventh, eighth, and ninth grades of the school system under the supervision of the district superintendent and board of trustees of the school district, and subject to the regulations and approval of the state board of education and the state superintendent of public instruction.

2. A senior high school is a public school as defined in the general school. laws and is an integral unit of the public school system which comprises what is ordinarily designated as the work of the tenth, eleventh, and twelfth grades of the school system, under the supervision of, the district superintendent and board of trustees of the school district, or of the county high school principal and county high school board. . .

3. A six-year high school is a public school as defined in the general school laws and is an integral unit of the public school system which comprises what is ordinarily designated as the work of grades seven through twelve inclusive. . .

4. A regular four-year high school is a public school as defined in the general school laws and is an integral unit of the public school system which comprises what is ordinarily designated as the work of grades nine through twelve, inclusive, of the school system.5

Provisions are made for accrediting or denying accreditation to these schools according to section 75-107 of the school laws: "The state board of education shall have power and it shall be its duty . . to accredit such high schools as maintain the standards of work prescribed by the board on all such matters of promotion and accrediting." 6

5 School Laws of the State of Montana, State Department of Public Instruction, 195\%, p. 166.

6 Ibid., p. 16. 
Size of enrollment is inversely related to the rate of state support allocated to secondary schools; moreover, secondary and elementary schools are given state funds according to different schedules of payment. Should schools not maintain standards sufficient to justify being accredited, they are denied foundation funds:

High Schools. For a school having an average number belonging (ANB) of forty (40) or fewer pupils in a school, the guaranteed budget shall not exceed four hurdred ninety-five dollars $(\$ 495.00)$ for each pupil. High schools. . . shall not receive state equalization aid unless they have been accredited by the state board of education.

For a secondary school having an ANB of more than forty (40) pupils, the maximum four hundred ninetyfive dollars $(\$ 495.00)$ shall be decreased at the rate of two dollars and twenty cents (\$2.20) for each additional pupil until the ANB shall have reached a total of one hundred (100) such pupils. For a school having an ANB of more than one hundred (100) pupils, the maximum of three hundred sixty-three dollars (\$363.00) shall be decreased at the rate of fiftyfive cents (\$0.55) for each additional pupil until the number ANB shall have reached two hundred (200) pupils. For a school having an ANB of more than two hundred (200) pupils, a maximum of three hundred eight dollars $(\$ 308.00)$ shall be decreased at the rate of twenty-three cents ( $\$ 0.23)$ for each additional pupil until the total number, ANB, shall have reached three hundred (300) pupils. For a school having an ANB of more than three hundred (300) pupils, the maximum of two hundred eighty-five dollars $(\$ 285.00)$ shall be decreased at the rate of seven cents $(\$ 0.07)$ for each additional pupil until the total number, ANB, shall have reached six hundred fifty (650) pupils. Schools having an ANB in excess of six hundred fifty (650) pupils shall receive two hundred sixty dollars and fifty cents $(\$ 260.50)$ per pupil, provided that the maximum per pupil for all pupils, ANB, shall be computed on the basis of the amount allowed herein on account of the last eligible pupil, ANB. 
In computing the amount guaranteed for the foundation program, only junior high schools which have been approved and accredited by the state board of education shall be considered a part of the secondary enrollment.?

In a state such as Montana it is of course necessary to make special provision for pupils in truly isolated areas. The definition and classification of an "isolated" school is flexible enough and general enough to meet different local situations and changing conditions:

The term, "isolated high school," shall mean a high school having an ANB of less than twenty (20) pupils, the maintenance and operation of which as an isolated school has been approved in the manner hereinafter provided....

Before any high school . . . may be approved as an isolated high school, the board of trustees of the district wherein said school is located shall, on or before the fifteenth day of June in each year, make written application to the budget board for such approval. Such application shall be acted upon at the time the budget of the applying district is considered, and such application shall be granted if said budget board and the county superintendent of schools shall find and determine that transportation of the pupils of such school to another school is impractical by reason of the existence of obstacles to travel, such as mountains, rivers, poor roads, distance of the pupils' homes from county roads or highways, or the distance of such isolated school from the nearest open school having room and facilities for the pupils of such isolated school .. . and if none of the above mentioned circumstances exist, such application shall be denied.

Although high schools of fewer than twenty pupils

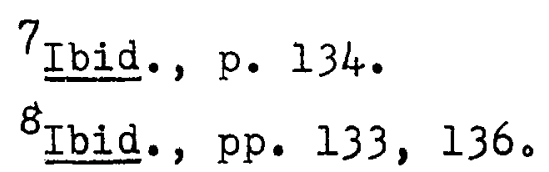


may be denied approval as "isolated," they are not necessarily denied accreditation; such schools are denied state funds and are wholly dependent on local sources for support. A few such schools exist in Montana at the present time.

When feasible, high schools may be created, abolished, or consolidated. Provisions for doing so are included in the school laws. Especially pertinent to this study are the provisions made for consolidating high schools. Section 75-4233 on "Consolidation" provides:

Whenever it shall appear to the board of county commissioners to be for the best interests of any two or more high schools in the county and for the high school system in the county as a whole to effect a consolidation of such high schools it shall have the power and authority to effect such consolidation and to determine all questions involved in effecting such consolidation, provided, however, that before such consolidation shall. become effective it shall be approved by the state superintendent of public instruction.9

\section{School Finance}

In a sense, Montana is like a family living in a mansion on a cottage income--it is the fourth largest state, with a population estimated at 688,000 by the Bureau of the Census as of July 1, 1958. This is a population less than half that of some of the more densely populated counties in

$$
{ }^{9} \text { Ibid., p. } 186 .
$$


the East. As a result the expenditures for overhead are high, while returns for monies spent are low, when compared with more populous areas. In a recent issue of Montana Business Review some significant figures on taxation and income are given. They help provide specific answers to some of the following important questions: How does the state obtain its revenue? How does it spend it? Is Montana's tax burden high, compared to that of other states? If so, why?

Three tables from the article are reproduced (in all or in part) as Tables 1, 2, and 4 of this study. The article says:

[Of] interest to the individual taxpayer are the per capita tax revenues and the data relating tax revenue to personal income reported in Tables 2 and 3. . . The figures in Tables 2 and 3 indicate that Montanans are carrying a heavy tax burden in relation to all the forty-eight states, although comparisons of Montana taxes with neighboring states are not unfavorable. Per capita revenue (total general revenue divided by total population) from all state and local taxes in Montana in fiscal 1957 amounted to $\$ 187.78$, compared to a national per capita figure of $\$ 169.14$. The median, or middle amount for 48 states and the District of Columbia was $\$ 160.98$. Montana's rank among the states was tenth. In other words, in only nine states in 1957 did residents pay higher per capita taxes to state and local governments than in Montana. Included in those states were the two most populous--New York and California; two other eastern states--Massachusetts and Delaware; and five western states. . . A comparison of data for Montana and its neighboring states places Montana squarely in the middle. 10

10 Maxine C. Johnson, "State And Local Taxes in 
TABEE 1

PER CAPITA GENERAL REVENUE OF STATE AND LOCAL GOVERNIRINS, HDNANA, STY

NEIGHBORING STATES, AND THE UNITED STATES, FISCAI 1957*

\begin{tabular}{|c|c|c|c|c|c|c|c|c|c|}
\hline Revenue Source & liontana & Idaho & Vash. & Oregon & nyo. & S. Dak. & I. Dak. & $\begin{array}{l}\text { United } \\
\text { States }\end{array}$ & U.S. \\
\hline \\
\hline All general revenue & 275.81 & $\$ 227.09$ & $\$ 265.09$ & 277.56 & 341.35 & 5241.97 & 259.93 & $: 224.10$ & t2227.09 \\
\hline $\begin{array}{l}\text { From state and local } \\
\text { sources }\end{array}$ & & & & & & & & & \\
\hline All taxes & 187.78 & 155.00 & 188.15 & 200.58 & 191.79 & 154.33 & 156.55 & 169.14 & 160.98 \\
\hline $\begin{array}{l}\text { Nontax-charges and } \\
\text { miscellaneous revenue }\end{array}$ & 3020 & $35 \quad 23$ & 1723 & 3735 & 6572 & 3710 & 6010 & 3230 & 373 \\
\hline From the federal & $3 \% 0<0$ & 33.35 & 4103 & 30.37 & 03.10 & 36.40 & $000+2<$ & 32.39 & $31-.44$ \\
\hline government & 48.84 & 36.27 & 29.73 & 38.53 & 34.88 & 39.73 & 31.96 & 22.57 & 25.47 \\
\hline \multicolumn{10}{|l|}{$\begin{array}{l}\text { State rank according to } \\
\text { per capita amount }\end{array}$} \\
\hline All general revenue & 7 & 25 & 9 & 6 & 2 & 16 & 11 & & \\
\hline \multicolumn{10}{|l|}{$\begin{array}{l}\text { From state and local } \\
\text { sources }\end{array}$} \\
\hline All taxes & 10 & 29 & 9 & 6 & 7 & 22 & 21 & & \\
\hline \multirow{2}{*}{$\begin{array}{l}\text { Nontax--charges and } \\
\text { miscellaneous revenue }\end{array}$} & 17 & 70 & 7 & 75 & 3 & 76 & 2 & & \\
\hline & \multicolumn{9}{|c|}{ From the federal } \\
\hline government & 4 & 11 & 18 & 9 & 1 & 8 & 15 & & \\
\hline
\end{tabular}

*State and Local Government Finances in 1057, as reprinted in "State and Local Taxes in Hontana," Montana Business Review, XI, No. 4 (April, 1959), 5. 
Table 2 shows that Montanans paid almost exactly one tenth of their average personal incomes for state and local taxes: $\$ 99.76$ per $\$ 1000$.

The ratio of state and local taxes to personal income provides the most significant measure of tax burden among the states, since it gives some indication of the ability to pay. Relatively high per capita taxes may not be burdensome, if incomes are also high. . . Montana's rank was seventh, exceeded jiily by North Dakota, Mississippi, South Dakota, Vermont, Louisiana, and Oregon. It is worth noting that this list is quite different from the states named above as having the highest per capita taxes; for the most part, those states are also high income states. 11

Montana shares the problem of state and local taxes

with its neighboring states. The article comments:

In addition to their geographic location, the seven northwest states, including Montana, have a number of other common characteristics which tend to result in high cost administration and government services. All have relatively large areas and small populations. - All have predominantly natural resource economies, based on the production of raw materials rather than finished goods, and all except Washington and Wyoming had per capita incomes somewhat below the national in 1957. Although each state also has distinctive qualities and individual problems, various combinations of these common characteristics have contributed $\mathrm{y}_{2}$ the relatively heavy state and local tax burdens.

During the 1957 fiscal year receipts from the state sale of timber and from rentals of state land totaled

Montana," Montana Business Review, XI, No. 4 (April, 1959), 5 .

$11_{\text {Ibid. }}$ p. 8 .

12 Ibid. 
TABLE 2

GELERAL REVENUE (FISCAL 1957) PER \$1,000 OF PERSOHEL INCO:E (CALEITAK I957), SDNTATA, SIX NEIGHBORING STATES, AND THE UNITED. STATES

\begin{tabular}{|c|c|c|c|c|c|c|c|c|c|}
\hline Revenue Sources & Montana & Iciaho & rash. & Oregon & "yo. & S. Dak. & N. Dak. & $\begin{array}{l}\text { United } \\
\text { States }\end{array}$ & U.S. \\
\hline Amount & & & & & & & & & \\
\hline $\begin{array}{l}\text { All general revenue } \\
\text { From state and }\end{array}$ & $\$ 146.53$ & 140.44 & $\$ 124.72$ & 1442.92 & 168.27 & $\$ 155.98$ & 180.81 & . & 散122.73 \\
\hline $\begin{array}{l}\text { local sources } \\
\text { All Taxes }\end{array}$ & $\begin{array}{r}120.58 \\
99.76\end{array}$ & $\begin{array}{r}11.8 .01 \\
95.85\end{array}$ & $\begin{array}{r}110.73 \\
88.51\end{array}$ & $\begin{array}{l}123.08 \\
103.33\end{array}$ & $\begin{array}{r}126.49 \\
94.40\end{array}$ & $\begin{array}{l}130.37 \\
106.26\end{array}$ & $\begin{array}{l}158.51 \\
116.33\end{array}$ & $\begin{array}{l}99.40 \\
.83 .42\end{array}$ & $\begin{array}{r}107.21 \\
88.51\end{array}$ \\
\hline $\begin{array}{l}\text { Nontax-chsrges and } \\
\text { miscellaneous }\end{array}$ & & & & & & & & & \\
\hline $\begin{array}{c}\text { revenue } \\
\text { From the federal }\end{array}$ & 20.83 & 22.16 & 22.22 & 19.75 & 32.09 & 24.11 & 42.17 & 15.97 & 18.45 \\
\hline government & 25.95 & 22.43 & 13.99 & 19.84 & 41.78 & 25.61 & 22.31 & 11.13 & 15.20 \\
\hline $\begin{array}{l}\text { State rank in the re- } \\
\text { lationshio to versonal } \\
\text { income of: }\end{array}$ & & & & & & & & & \\
\hline All general revenue & 8 & 11 & 22 & 7 & 6 & 5 & 1 & & \\
\hline State and local taxes & 7 & 12 & 25 & 6 & $u_{4}$ & 3 & 1 & & \\
\hline
\end{tabular}

*State and Local Government Finances in 1957, as reurinted in "State and iocal Texes in liontana," Nontana Business Revier, XI, No. 4 (April, 1959), 8. 
$\$ 493,284.53$. This was deposited according to law in the state treasury and set aside for school purposes and capital building funds. Table 3, taken from the Biennial Report of the Superintendent of Public Instruction, shows the source of funds for the operation of Montana schools for a typical period.

How is this state and local tax money spent? Table 4, which is adapted from the Table 4 of the article quoted, itemizes the two major areas of expense: education and highways. It summarizes under "all other expenses" those amounts which were itemized in the original table.

Sixty-four percent of all general expenditures was allocated to education and highways -36 percent for education and 28 percent for highways. Montana's expenditure of 28 percent of general expenditures for highways was substantially higher than the 19.3 percent of the total expended by all state and local governments combined, but Montana has a population of 9 persons per mile of highways, compared to 49 per mile in the United States. The proportion expended for higher education was greater and for elementary and secondary education slightly lower than for all states. The proportion spent for all education was approximately the same.

- In most instances, Montana occupied a median position among her neighboring states in the allocation of funds for various purposes. Per capita expenditures In Montana were well above both the average and median at the national level. . . Per capita highway expenditures were the fifth highest in the nation; education, the tenth highest...

Higher-than-average expenditures for schools and highways, to maintain Montana's large number of school districts, the six units of the University of Montana, and the vast highway system, therefore account for the larger total per capita expenditures 
TABLE 3

SOURCES OF REVENUE FOR MONTANA SCHOOLS*

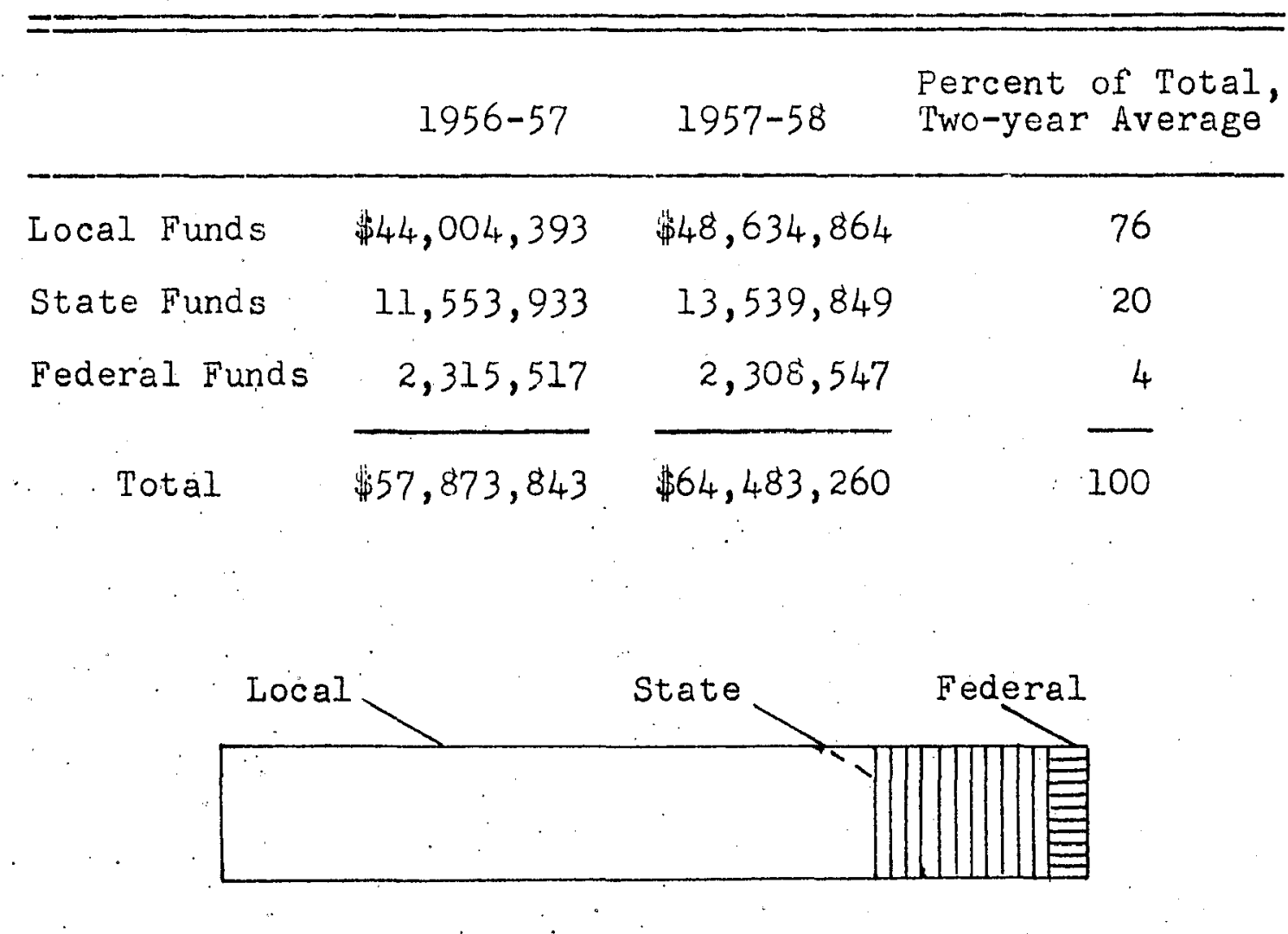

Sources of School Revenue

*Biennial Report of the Superintendent of Public Instruction of Nontana, 1956. 
TABLE 4

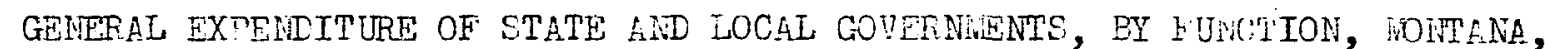
SIX NEIGHBORING. STATES, AND THE UNITED STATES, FISCAL 1957*

\begin{tabular}{|c|c|c|c|c|c|c|c|c|c|}
\hline \multirow[b]{2}{*}{ Function } & \multirow{2}{*}{$\begin{array}{l}\text { Amount } \\
\text { (ontena } \\
\text { (\$1000) }\end{array}$} & \multicolumn{8}{|c|}{ Percent of Total } \\
\hline & & Wontana & Idaho & Wash. & Oregon & Wyo. & So. Tak. & N. Dak* & U.S. \\
\hline All general expenditure & 189,039 & 100.0 & 100.0 & 100.0 & 100.0 & 100.0 & 100.0 & 100.0 & 100.0 \\
\hline Educeticn, total** & 67,998 & 36.0 & 35.0 & 36.0 & 38.8 & 36.5 & 34.9 & 31.8 & 35.0 \\
\hline Higher education & 13,510 & 7.1 & 5.9 & 6.8 & 7.1 & 6.8 & 7.4 & 7.3 & 4.8 \\
\hline Primary and secondary & 53,018 & 28.0 & 28.3 & 28.6 & 30.9 & 28.7 & 26.7 & 23.8 & 29.3 \\
\hline Highweys & 53,021 & 2.8 .0 & 25.7 & 20.0 & 21.3 & 28.3 & 32.2 & 28.5 & 19.3 \\
\hline All other expenses & 68,018 & 35.9 & 39.5 & 44.0 & 39.9 & 35.3 & 33.0 & 39.8 & 45.6 \\
\hline
\end{tabular}

*Adapted from State and Local Governilent Finances in 1957, as reprinted in "State and Local Taxes in Montana," Montana Business Revier, XI, No. 4 (April, 1959), 9. ized here.

* Eaucation, total" includes amounts for "other education" of the original table, not item- 
by its state and local governments. Despite these expenditures, many of our highways and streets, our school buildings and the salaries paid to instructors leave something to be.desired. . . But state and local taxes are already high. The chances are that they will remain high. 13

\section{Summary}

Montana is the fourth largest state in the nation, with a population of only 688,000 and a density of only 4.6 persons per square mile. Twenty-eight per cent of Montana's area--33,579,131 acres--is United States government land. More than one-third of the state is mountainous; the eastern portion is composed of semi-arid, high, rolling plains. Large farms or ranches are the rule, and settlements cluster along major rivers and in the intermontane valleys. The climatic range within the state is extreme. There are many good paved highways but also many miles of unimproved side roads in the state. Distance itself, combined with winter blizzards and spring thaws, make pupil transportation a very real problem. The effects of isolation are, however, often overrated.

Four types of organized secondary schools exist within the state: the junior high school, and the threeyear, four-year, and six-year high schools. Accrediting these schools is the responsibility of the state board of

\section{${ }^{13}$ Ibid., pp. 10-11.}


education. The actual amount of state support is partially in proportion to total high school enrollment. Smaller schools receive the largest per-pupil allotments, and the amounts decrease as the size of the high school enrollments increases. Provisions are made by law for isolated high schools, defined as those with less than twenty pupils, which have been approved by the budget board and the county superintendent of schools. School laws make consolidation of smaller schools into larger units possible.

Montanans carry a heavy tax burden compared with other states and the United States as a whole. In only nine states do residents pay higher per capita taxes. In only six do they pay more per 1,000 of personal income-in other words, a larger proportion of what they earn. Reasons for the relatively high tax burden include the geographic factors of large area and sparse population, and an economy based on primary industries. Despite the higher-than-average expenditures for schools and highways, these both leave much to be desired. Taxes are high; returns are low。 


\section{CURRICULA AND ENROLLMENT}

One of the factors contributing to the high cost of Montana's educational system is the number of small high schools. Small secondary schools, because of their disproportionately high overhead and high per-pupil cost, offer minimum or sub-minimum academic curricula. School enrollment, school size, and their relationship to the science program are discussed in the chapter which follows.

School Enrollment

There were 41,166,000 students enrolled in the schools of the United States at the beginning of the 1957-

- 58 school year. Of this number, which represents nearly 24 per cent of the total population, 8,956,000 were enrolled in the high schools. 14 Montana had at the beginning of the 1958-59 school year a total school enrollment of $116,897,15$ about 0.28 per cent of the United States enrol1ment. This figure of 116,897 represents only 16.9 per cent

14 World Almanac, 1959, p. 486 . 15 Montana Almanac, 1959-1960, p. 159. 
of the state's estimated population, as contrasted with 24 per cent for the nation.

These pupils are distributed among the state's 1,246 elementary schools and 216 secondary schools. The smallest secondary school enrolled 10 students in 1958-59, while the largest secondary school enrolled more than 2,000.

Statistical information regarding these secondary schools is furnished to the State Superintendent of Public Instruction each fall by the school administrators. This material is sent in on a printed form commonly referred to as "Form A.". (See Appendix $A_{0}$ ) This form contains information about classes taught, size of classes, instructors' names, and the training and experience of instructors. Most of Montana's secondary schools are public schools; therefore this. study is concerned with an analysis of the material included in the Form $A$ reports received from these public secondary schools, and more specifically with that information which relates to the teaching of science. There are 190 of these schools: 173 are high schools (grades nine through twelve or ten through twelve) and the other 17 are junior high schools (grades seven through nine).

There were 40,065 pupils enrolled in these public secondary schools during 1958-59, the school year for which the Form A reports were examined. Of this number 33,761, 
or more than 84 per cent, were enrolled in grades nine through twelve. ${ }^{16}$ The 33,761 figure was obtained by subtracting the ninth grade enrollment figures from junior high enroliments, and adding these to the enrollment figures for four-year high schools. The remaining 6,304 were seventh and eighth graders in junior high schools.

Since World War II there has been an emphasis on science and science teaching. An unprecedented increase in scientific activity during this period has been brought about by an increase in demand for both military and consumer goods. This demand has in turn created a need for scientific and technological personnel which exceeds the supply. Part of the blame for this shortage of trained scientists and technicians has been placed on the teaching of science in the secondary schools of the nation, and on the training of science teachers by the colleges and universities. Some critics hold the secondary schools and the teacher-training institutions chiefly responsible. Admiral Rickover, one of the best known and most vocal critics of education in the public schools, said that he testified the following before the Appropriations Committee of the House of Representatives: "I am a customer for the products of our schools. I tried to get people to 
help me do a job in nuclear-power development, and I found the product of our schools quite unsatisfactory." 17

Studies on Enrollment

In the past few years many studies have been made of the enrollment in the sciences. Among these studies is one conducted by the U.S. Office of Health, Education, and Welfare in 1956. In analyzing the demand for and the shortage of scientific and technological manpower, the study states:

Many factors have contributed to the shortage, among them a period of low birth rate. Our rapid expansion of technology has increased the need for scientific manpower. The demand for unskilled labor has rapidly declined while the demand for skilled labor has risen in our industrialized society.

In addition to the increased demand for specialized personnel to raise our standard of living, there are military demands. The world is engaged in an international conflict--a conflict of ideas-and, whether we like it or not, we are if a race with the communists for military supremacy.

The U.S. News and World Report, in its November 30, 1956, issue, used material from an interview with Arthur E. Bestor of the University of Illinois in attempting to show that our hign schools are not enrolling in the sciences the

17 Hyman G. Rickover, "The World of the Uneducated," Saturday Evening Post, CCXXXII, No. 22 (November 28, 1959),

18

Offerings and Enrollments in Science and Mathematics in Public High Schools, U.S. Department of Health, Education, and Welfare, 1956, p. 2 . 
number of pupils necessary to guarantee a continuing and sufficient supply of young people to carry on in the field of science.

According to Harold C. Hand, replying in the American Association of University Professors' Bulletin, ${ }^{19}$ the interview with Bestor distorted information taken from two U.S. Office of Education publications. Hand takes issue with the statement made by Bestor that "more than half of the high schools in the United States offer no physics; roughly a quarter offer neither physics nor chemistry. "20 He points out that schools which offer neither chemistry nor physics enroli less than two per cent of the total public secondary school population, and furthermore that many of these schools alternate physics and chemistry, so that to take any one year's figures would be misleading. (This arrangement is very common in Montana.)

In an article in School Science and Mathematics John Nietz shows that a number of popular writers and also some individuals of noted scientific attainment have used

19Harold C. Hand; "Black Horses Eat More Than White Horses, "American Association of University Professors' Bulletin, June, 1957, pp. 266-67, 274-75.

20 Interview with Arthur Bestor, "We Are Less Educated Than 50 Years AgO," U.3. News and World Report, November 30, 1956, p. 68. 
the same figures referred to by $\operatorname{Hand}^{2 I}$ to present a distorted picture of what the public schools are actually doing. It is Nietz's contention that proportionately more students, not less, are enrolled in the science and mathematics courses of our public schools today than were formerly enrolled. In a table which he includes in his article he shows that in 1900 there were enrolled in physiology 2.3 per cent, in physics 1.6 per cent, and in chemistry 0.6 per cent of the population between the ages of fourteen and seventeen. In 1948-49 biology enrolled 12.7 per cent, physics 3.5 per cent, and chemistry 5 per cent of the same age group. 22

Scott, in the American Association of University Professors: Bulletin, points up the fact that:

The question of how much science education is necessary for satisfying personal living is a more difficult and philosophical question. Neither educators nor laymen will find answers to either of these major questions in enrollment data, but [and he refers here to the contribution of Hand] setting the record straight was a desirable preliminary to further work on much more basic questions. Perhaps now everyone can get on with the job. ${ }^{3}$

${ }^{21}$ Bulletin: Statistical Summary of Education, U.S. Office of Education, 1949-1950; and Pamphlet No. 118, U.S. Office of Education, 1956.

22 John A. Neitz, "More Students Taking Science and Mathematics," School Science and Mathematics, October, 1957, pp. 5i2-14.

${ }^{23} \mathrm{C}$. Winfield Scott, "Neglected Issues in the 
Although Scott does not elaborate on what he means by "more basic questions," It is quite clear that he is referring to the quality of the teaching as well as the quantity. Although much more difficult to measure, it is the former as much as the latter that has been responsible for the criticism of the secondary schools' part in the teaching of science.

For some years we have been too much impressed by numbers enrolled and not enough concerned about the quality of instruction. Recent statistics released by the Ohio Department of Education refer to the fact that only eighteen one-teacher schools remain in Ohio. Others have been absorbed into larger systems, thus making possible, at least theoretically, more efficient educational procedures. But that improved quality does not necessarily follow consolidation is evidenced by a news item in the Columbus Citizen-Journal of November 10, 1959. Referring to a survey by Harold J. Bowers, Assistant State Superintendent of Public Instruction and chairman of the Ohio North Central Committee, the item reported, "Ohio had 517 of the 1283 public and private-parochial schools accredited and holding membership in the North Central Association of

Science Subjects Controversy," American Association of University Professors ' Bulletin, December, $1957, p_{0} 647$. 
Colleges and Secondary Schools." Bowers told the State Board of Education that since the survey was made the number of high schools had been lowered to 1106 through consolidation but that the number of non-accredited institutions remained the same.

Quality of instruction depends upon many factors: facilities, teacher preparation, textbooks, methods of presentation, enthusiasm of the teacher, and quality of the administration, to name a few. Many of these are difficult to measure, but until we have done our best to evaluate them and have used the resulting information to get a composite picture of instruction, we will have no adequate basis upon which to judge the effectiveness of the American secondary school. It is quite unscientific to use statistical information based upon enrollment alone, in any but a limited sense. It is therefore all the more surprising that scientists of note have been guilty of doing just that.

The enrollment statistics for Montana used in this study are taken from the annual Form A reports of the school administrators. All figures used here, unless otherwise noted, are based upon statistics compiled in the fall of 1958-59. They therefore represent all the public high schools and all the formally organized junior high schools in the state. 
In a few cases some information was omitted by the administrators. Where this omission concerned class enrollment, estimates were made based upon enrollment in other classes. Although private and parochial high schools also submit reports in Miontana, these were not included; only those reports submitted by state-supported public secondary schools were processed.

Size of Montana's High Schools

Table 5 is introduced to show the distribution of Montana's secondary schools according to size. Most of the schools are in the small brackets, more than 75 per cent being below the 200-299 interval. There are more in the 100-199 interval than in any other; in fact, more than in the four highest intervals combined. The table makes use of a system of school classification used by Kansas State Teachers' College in a report published in March, 1956, 24 and in a bulletin released by the U.S. Office of Education in 1950.25

In order to provide data from other areas to compare with the data shown in Table 5, enrollment figures from

24 John Breukelman and Ted F. Andrews, "Offerings and Enrollments in the Secondary school sciences in ransas in 1954-1955," Kansas State Teachers' College, March, 1956. ${ }^{25}$ Philip G. Johnson, The Teaching of Science in Public High Schools, U.S. Office of Education, 1950. 


\section{TABLE 5}

NUMBER AND PERCENTAGES OF PUBLIC SECONDARY SCHOOLS IN MONTANA IN EACH SIZE INTERVAL*

\begin{tabular}{lcccc}
\hline Enrollment & $\begin{array}{c}\text { No. of } \\
\text { Schools }\end{array}$ & $\begin{array}{c}\text { Per Cent } \\
\text { of Total }\end{array}$ & $\begin{array}{c}\text { No. of Junior } \\
\text { Highools }\end{array}$ & $\begin{array}{c}\text { High Schools } \\
\text { Only }\end{array}$ \\
\hline $10-24$ & 12 & 6.3 & 0 & 12 \\
$25-49$ & 32 & 16.8 & 1 & 31 \\
$50-74$ & 26 & 13.7 & 0 & 26 \\
$75-99$ & 25 & 13.2 & 0 & 25 \\
$100-199$ & 49 & 25.8 & 4 & 45 \\
$200-299$ & 10 & 5.3 & 1 & 9 \\
$300-499$ & 14 & 7.4 & 1 & 13 \\
$500-999$ & 15 & 7.9 & 8 & 7 \\
$1000-2400$ & 7 & 3.7 & $\underline{2}$ & -17 \\
Totals & 190 & 100.1 & 17 & 173 \\
\hline
\end{tabular}

\footnotetext{
*Figures taken from Montana Educational Directory, 1958-59, Department of Public Instruction.
} 
four studies are presented in Table 6 . Those in the column at the left were obtained from a tabulation of enrollment statistics from all public high schools in $1945-46.26$ The second column shows the results of the study made by Philip Johnson in 1947-48, using a stratified random sampling of the nation's high schools. Galen Jones, in the foreword to this study, commented that "this study was undertaken to reveal the extent and nature of our science education enterprise at high-school levels. . . Summaries of . . local studies when compared with this national report may help to reveal local problems which can be studied and provide a basis for making needed improvements." 27

The third column of Table 6 is taken from the Kansas study by Breukelman and Andrews, and the statistics in the last column are from the present study. The Kansas study shows more schools in proportion in the $24-49$ and 50-74 enrollment groups; ${ }^{28}$ the other three columns all show the highest percentages in the 100-199 category.

In all cases there are more schools in the lower enrollment categories than in the higher enrollment groups.

26"Statistics of Public High Schools, 1945-46," Biennial Survey of Education in the United States, 1944-46, chap. v.

27 Johnson, Teaching of Science, pp. vii-viii. p. 7 .

28Breukelman and Andrews, Offerings and Enrollments, 
TAELE 6

A COMPARISON OF THREE STUDIES OF EIROLLWENT VITH STATISTICS ACCURULATED BY THE U.S. OFFICE OF EDUCATION FOR ALE U.S. PUBLIC HIGH CCHOOLS

\begin{tabular}{|c|c|c|c|c|c|c|c|c|}
\hline \multirow[b]{2}{*}{ School Size } & \multicolumn{2}{|c|}{$\begin{array}{c}\text { U.S. Office of } \\
\text { Education: } 1945-46 \\
\text { AlI High Schools }\end{array}$} & \multicolumn{2}{|c|}{$\begin{array}{cl}\text { U.S. Office of } \\
\text { Education: } & 1950\end{array}$} & \multicolumn{2}{|c|}{ Kansas } & \multicolumn{2}{|c|}{ Nontana* } \\
\hline & $\begin{array}{l}\text { Number of } \\
\text { Schools } \\
\text { Reporting }\end{array}$ & Per Cent & $\begin{array}{l}\text { Number of } \\
\text { Schools } \\
\text { Reporting }\end{array}$ & Per Cent & $\begin{array}{l}\text { Number of } \\
\text { Schools } \\
\text { Reporting }\end{array}$ & Per Cent & $\begin{array}{l}\text { Number of } \\
\text { Schools } \\
\text { Renorting }\end{array}$ & Per Cent \\
\hline $\begin{array}{l}10-24 \\
25-49 \\
50-74 \\
75-99 \\
100-199 \\
200-299 \\
300-499 \\
500-999 \\
1000-2400 \\
\text { over } 2400\end{array}$ & $\begin{array}{r}975 \\
2,686 \\
3,117 \\
2,548 \\
5,920 \\
2,643 \\
2,376 \\
2,212 \\
1,328 \\
142\end{array}$ & $\begin{array}{r}4.1 \\
11.2 \\
13.0 \\
10.6 \\
24.7 \\
11.1 \\
9.9 \\
9.2 \\
5.6 \\
0.6\end{array}$ & $\begin{array}{r}29 \\
74 \\
71 \\
83 \\
184 \\
88 \\
78 \\
68 \\
37 \\
3\end{array}$ & $\begin{array}{r}4.1 \\
10.4 \\
9.9 \\
11.6 \\
25.7 \\
12.3 \\
10.9 \\
9.5 \\
5.2 \\
0.4\end{array}$ & $\begin{array}{r}42 \\
163 \\
140 \\
75 \\
132 \\
43 \\
29 \\
51 \\
10 \\
2\end{array}$ & $\begin{array}{r}6.1 \\
23.8 \\
20.5 \\
10.9 \\
19.2 \\
6.2 \\
4.2 \\
7.4 \\
1.4 \\
0.3\end{array}$ & $\begin{array}{r}12 \\
31 \\
26 \\
25 \\
45 \\
9 \\
13 \\
7 \\
5 \\
0\end{array}$ & $\begin{array}{r}6.9 \\
18.0 \\
15.0 \\
14.5 \\
26.0 \\
5.2 \\
7.5 \\
4.0 \\
2.9 \\
-.\end{array}$ \\
\hline Totals & 23,947 & 100. & 715 & 100. & 687 & 100. & 173 & 100. \\
\hline
\end{tabular}

*Grades 9-12 
Figure I illustrates this fact. It also shows graphically that Montana is far from unique in supporting a relatively large number of small schools and proportionately few in the larger enrollment categories, because of its scattered population and its 1160 school districts. 29

Most Montana high schools--93.1 per cent--enroll fewer than 500 pupils. This exceeds Conant's estimate of 70 per cent for the number of high schools in the United States which fall below what he considers a desirable enrollment: those with a graduating class of at least 100 . Schools meeting this criterion would with few exceptions enroll 500 pupils or more. 30

The figures shown in the other studies cited in Table 6 also exceed Conant's estimate. Since the study of all schools in the United States was made in 1945-46, it is possible that the figure of 84.5 per cent (total percentage of all high schools enrolling less than 500, column 1) has now become smaller; however, Johnson's study made two years later showed no significant change ( 84.9 per cent), so it is possible that Conant's estimate was a conservative one. One of the criticisms most often voiced by those who

\footnotetext{
${ }^{29}$ Public Schools of Montana, George Peabody College for Teachers, 1958, p. 45 .

30 James B. Conant, The American High School Today, 1959, p. 80 .
} 
FIGURE I

RELATIVE NUMBERS OF PUBLIC HIGH SCHOOLS IN VARIOUS ENROLLMENT CATEGORIES, MONTANA AND THE NATION*

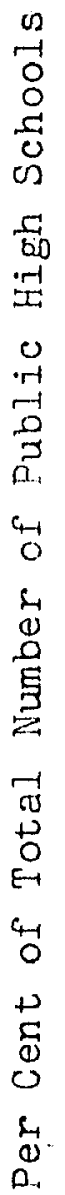

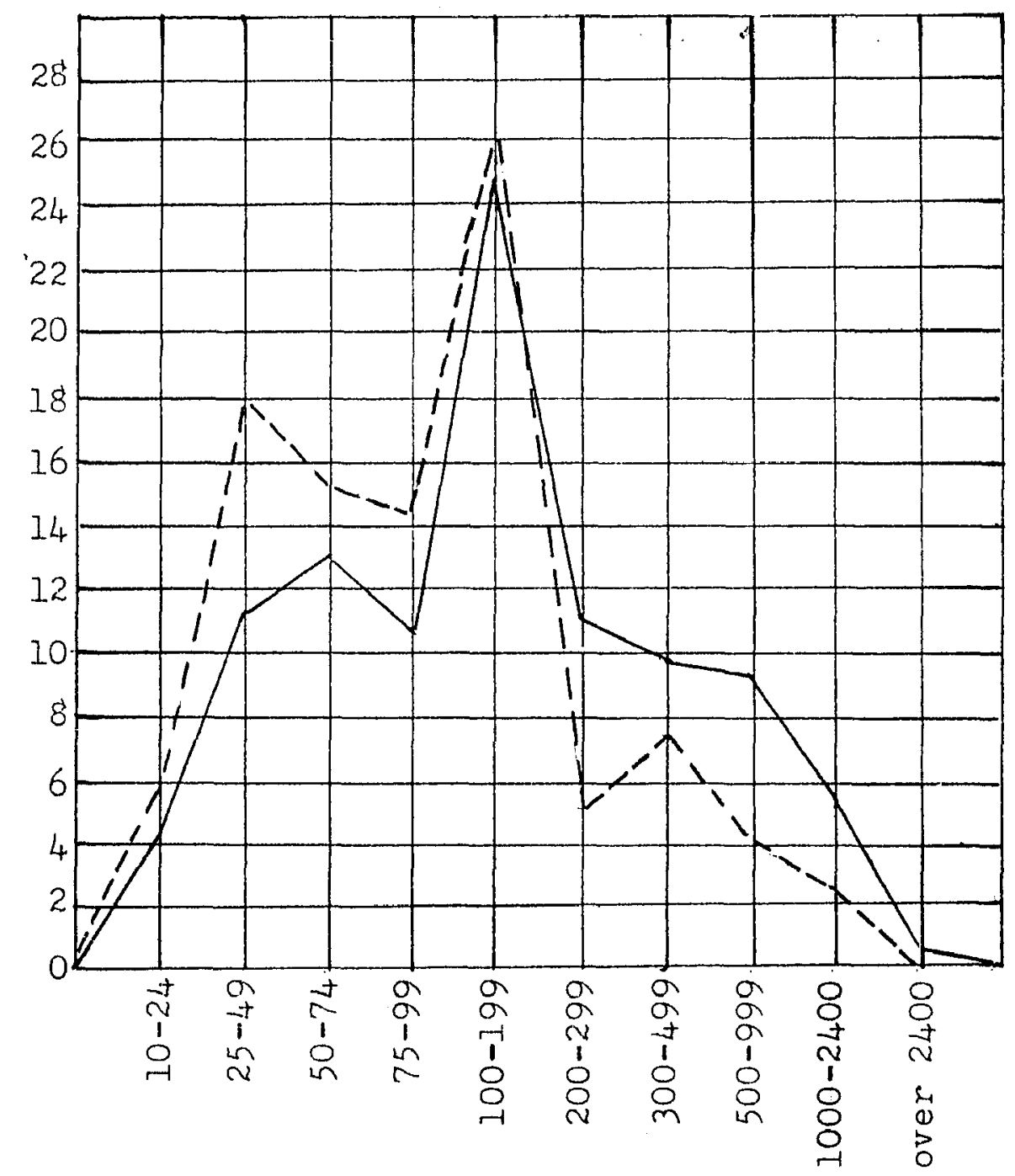

Categories According to Number Enrolled

The Nation as a whole

- - - Montana

*Based on the percentages in Table 6. 
have argued against using only number of schools in a study such as this is that number of schools alone creates a false impression if it is used without citing enrollment figures at the same time. Table 7 gives the enrollment figures for Montana public high schools, using the same school size categories as Tables 5 and 6 . The table shows that the 161 high schools having less than 500 pupils enroll 18,602 students, or 55.1 per cent of the total. By Conant's criterion, it would seem that over half of Montana's high school students are enrolled in schools of less than optimum size (that is, schools with graduating classes numbering less than 100). Figure II illustrates graphically the comparison between the number of these schools and the enrollment. Both Table 7 and Figure II omit seventh and eighth grade figures, and deal only with grades nine through twelve.

\section{Distribution of Science Teachers}

The distribution of the 431 teachers whose teaching programs were processed as part of this study is shown in Table 8 in relation to school size. The 431 include all Montana public school teachers who were teaching one or more regularly scheduled satence classes in grades seven through twelve during 1958-59. Of these 431 teachers, 387 were engaged in teaching science in the high schools, 


\section{TABLE 7}

NUMBER OF PUPILS ENROLLED IN MONTANA PUBLIC HIGH SCHOOLS IN 1958-59 IN EACH OF THE. SCHOOL SIZE CATEGORIES*

\begin{tabular}{lcccc}
\hline School Size & $\begin{array}{c}\text { Number of } \\
\text { Secondary } \\
\text { Schools }\end{array}$ & Enrollment & $\begin{array}{c}\text { High } \\
\text { Schools } \\
\text { Only }\end{array}$ & $\begin{array}{c}\text { High School } \\
\text { Enrollment }\end{array}$ \\
\hline $10-24$ & 12 & 213 & 12 & 213 \\
$25-49$ & 32 & 1,154 & 31 & 1,121 \\
$50-74$ & 26 & 1,571 & 26 & 1,571 \\
$75-99$ & 25 & 2,136 & 25 & 2,136 \\
$100-199$ & 49 & 7,061 & 45 & 6,592 \\
$200-299$ & 10 & 2,307 & 9 & 2,058 \\
$300-499$ & 14 & 5,127 & 13 & 4,911 \\
$500-999$ & 15 & 9,534 & 7 & 5,586 \\
$1000-2400$ & 7 & 10,962 & 5 & 9,573 \\
Totals & 190 & 40,065 & 173 & 33,761 \\
\hline
\end{tabular}

*Source: Montana Educational Directory, 1958-59. 
FIGURF II

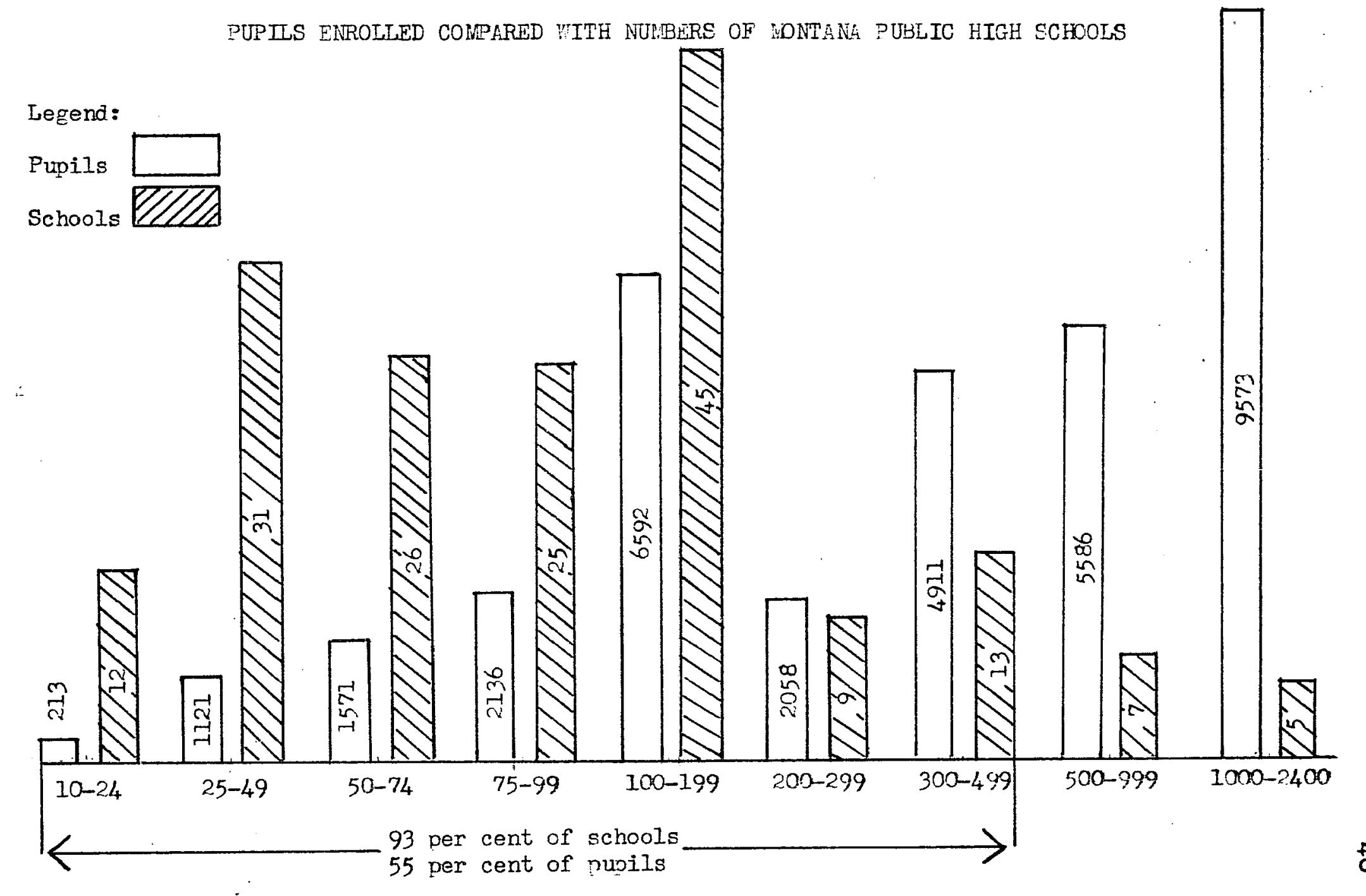




\section{TABLE 8}

DISTRIBUTION OF TEACHERS OF SCIENCE ACCORDING TO SCHOOL SIZE

\begin{tabular}{lcc}
\hline School Size & $\begin{array}{c}\text { Number' of Teachers } \\
\text { Teaching Science }\end{array}$ & Per Cent \\
\hline $10-24$ & 14 & 3.3 \\
$25-49$ & 47 & 12.0 \\
$50-74$ & 43 & 10.0 \\
$75-99$ & 46 & 10.6 \\
$100-199$ & 85 & 19.7 \\
$200-299$ & 19 & 4.0 \\
$300-499$ & 36 & 8.7 \\
$500-999$ & 78 & 16.9 \\
$1000-2400$ & 63 & 14.8 \\
\hline & $\frac{131}{100 .}$ & \\
\hline
\end{tabular}


grades nine through twelve. Although this report shows only 431 teachers that were teaching some science in the 190 schools studied, this does not mean that no other teachers were so engaged. Much excellent science teaching is done in self-contained seventh and eighth grade classrooms.

By comparing the per cent columns of Table 8 and Table 5, one can see, that not until the 300-499 size inter$\mathrm{val}$ is reached does the percentage of teachers teaching science equal or exceed the percentage of schools in any size interval. In the three largest enrollment categories the margin becomes greater. That the proportion is not comparable at the extremes of the tables is also obvious. The larger Montana high schools have a larger number of teachers of science in comparison with school enrollment than do the smaller high schools.

\section{Distribution of Science Courses}

The number and per cent of schools teaching the four main sciences, with relation to the same size intervals as the previous tables and omitting the 17 junior high schools in the state, is shown in Table 9. Special attention should be called to the omission of the junior high schools since it tends to distort the statistics concerning general science. Those school systems which have three-year sup- 
TABLE 9

NUMBER AND PER CENT OF MONTANA HIGH SCHOOLS TEACHING FOUR MAIN SCIINCES

\begin{tabular}{|c|c|c|c|c|c|c|c|c|c|}
\hline \multirow[b]{2}{*}{ School Size } & \multirow[b]{2}{*}{$\begin{array}{c}\text { Number } \\
\text { of } \\
\text { Schools }\end{array}$} & \multicolumn{2}{|c|}{ General Science: } & \multicolumn{2}{|c|}{ Biology: } & \multicolumn{2}{|c|}{ Chemistry: } & \multicolumn{2}{|c|}{ Physics: } \\
\hline & & $\begin{array}{l}\text { Number } \\
\text { of } \\
\text { Schools }\end{array}$ & Per Cent & $\begin{array}{c}\text { Number } \\
\text { of } \\
\text { Schools }\end{array}$ & Per Cent & $\begin{array}{c}\text { Number } \\
\text { of } \\
\text { Schools }\end{array}$ & Per Cent & $\begin{array}{c}\text { Number } \\
\text { of } \\
\text { Schools }\end{array}$ & Per Cent \\
\hline $10-24$ & 12 & 6 & 50.0 & 8 & 66.7 & 4 & 33.0 & 1 & 8.3 \\
\hline $25-49$ & 31 & 12 & 38.7 & 19 & 61.3 & 14 & 45.2 & 9 & 29.0 \\
\hline $50-74$ & 26 & 16 & 61.5 & 23 & 88.5 & 9 & 34.6 & 12 & 46.1 \\
\hline $75-99$ & 25 & 16 & 64.0 & 24 & 96.0 & 16 & 64.0 & 10 & 40.0 \\
\hline $100-199$ & 45 & 28 & 62.2 & 43 & 95.5 & 29 & 64.0 & 27 & 60.0 \\
\hline $200-299$ & 9 & 7 & 77.8 & 8 & 88.9 & 5 & 55.5 & 7 & 77.8 \\
\hline $300-499$ & 13 & 9 & 69.2 & 12 & 92.3 & 13 & 100 & 13 & 100. \\
\hline $500-999$ & 7 & 2 & 28.6 & 7 & 100. & 7 & 100 & 7 & 100 \\
\hline $1000-2400$ & 5 & 3 & 60.0 & 5 & 100. & 5 & 100. & 5 & 100. \\
\hline Totals & 173 & 99 & 57.2 & 149 & 86.1 & 102 & 59.0 & 91 & 52.6 \\
\hline
\end{tabular}


porting junior high schools as part of their organization commonly teach general science in the ninth grade. Reference to Table 5 shows that most of Montana's junior high schools are in fact in the larger enrollment categories. Since Montana has several different types of high schools-three-year, four-year, and six-year-ninth grade general science statistics could not be represented accurately in Table 9 unless the total group of 190 secondary schools were used, and this would in turn introduce more serious distortions.

From Table 9 it can be seen that biology is the science subject most of ten taught in Montana high schools: in 1958-59 it was part of the curriculum in 149, or 86.1 per cent, of the 173 high schools. The physics and chemistry columns of Table 9 need to be examined together with Table 10, which shows the number of schools teaching these two subjects the previous school year. Chemistry and physics are sometimes alternated, and any statistics showing what is taught in any one year might be misleading. These subjects are available in more schools than Table 9 seems to indicate, usually being taught in alternate years in small high schools.

Table 10 was prepared in order to show the true enrollment picture for chemistry and physics. It was compiled from the 1957-58 Form A reports; enrollment statis- 
TABLE 10

NUMBER OF MONTANA HIGH SCHOOLS TEACHING

CHEMISTRY AND PHYSICS IN 1957-58

\begin{tabular}{lccccc}
\hline School Size & $\begin{array}{c}\text { Teaching Both } \\
\text { Each } \\
\text { Year }\end{array}$ & $\begin{array}{c}\text { Alter- } \\
\text { nately }\end{array}$ & $\begin{array}{c}\text { Chemistry } \\
\text { Only }\end{array}$ & $\begin{array}{c}\text { Physics } \\
\text { Only }\end{array}$ & Neither \\
\hline $10-24$ & 0 & 3 & 5 & 1 & 3 \\
$25-49$ & 0 & 18 & 9 & 3 & 1 \\
$50-74$ & 0 & 18 & 5 & 2 & 1 \\
$75-99$ & 0 & 20 & 3 & 2 & 0 \\
$100-199$ & 12 & 30 & 1 & 2 & 0 \\
$200-299$ & 5 & 4 & 0 & 0 & 0 \\
$300-499$ & 11 & 2 & 0 & 0 & 0 \\
$500-999$ & 7 & 0 & 0 & 0 & 0 \\
$1000-2400$ & 5 & 0 & $-13^{*}$ & $10^{* *}$ & $5^{* * *}$ \\
Totals & 40 & 95 & 0 & 0 & 0 \\
\hline
\end{tabular}

*Represents 1,159 pupils enrolled in schools where no physics is taught.

**Represents 684 pupils enrolled in schools where no chemistry is taught。

***Represents 164 pupils enrolled in schools where neither is taught.

These starred totals were obtained by combining the appropriate enrollment figures given in the Montana Educational Directory, 1958-59, for those high schools where these subjects are not taught, according to the Form $A$ reports they submitted in 1957-58 and 1958-59. 
tics for an alternate year to the one in which this study was made were thus obtained. The table indicates that only 164 pupils are enrolled in Montana high schools where neither physical science is taught. This number represents 0.5 per cent of the state's total enrollment of 33,761 in grades nine through twelve. The ten schools where no chemistry is taught and the twenty-three schools where no physics is taught represent 684 and 1,159 pupils respectively, or 2 per cent and 3.4 per cent of the total high school enrollment.

Beginning with schools with an enrollment of 100-199 there is a marked shift from alternating physics and chemistry to teaching them both every year. All the large schools teach biology, chemistry, and physics each year. These figures are in conflict with estimates made in some of the popular articles written in the past few years, in which the statistics given tend to show that many high schools offer either no chemistry, no physics, or neither (cf.p. 34 of this study)。

General science is taught in fewer of the small schools than is biology. In the 10-24 size interval, only one-half of the schools teach it, while two-thirds offer biology (see Table 9). The figures are comparable for all the lower school size categories until the 200-299 bracket is reached. The differential beyond that point is more 
apparent than real, for the reasons pointed out on pages 48 and 50. Table 9 shows that 99 senior high schools, or 57.2 per cent, teach general science. A more accurate figure and per cent can be secured by adding in the state's seventeen junior high schools, since they usually represent systems in which general science is taught in the ninth grade. Using a corrected figure of 116 schools, a new per cent of 67.1 is secured, which more accurately represents the status of general science in Montana high schools. There are more classes in biology than in any other science subject, as well as more pupils. Table 11 shows the number of pupils enrolled in all secondary science classes, grades seven through twelve. Counting advanced biology, there are 346 biology classes enrolling 8,536 pupils, which represents almost 35 per cent of the enrollment in all science classes. It will be recalled that Table 9 showed a similarly higher number and per cent of Montana schools teaching this subject than any other science.

Chemistry and Physics Available to Montana Pupils Forty-one per cent of Montana high schools did not teach chemistry during 1958-59 (see Table 9). These figures compare rather closely with those of other studies that have been made--for example, the survey conducted by 
54.

TABLE 11

\begin{abstract}
NUMBERS OF PUPILS ENROLLED IN ALL SECONDARY SCIENCE CLASSES, GRADES 7-12
\end{abstract}

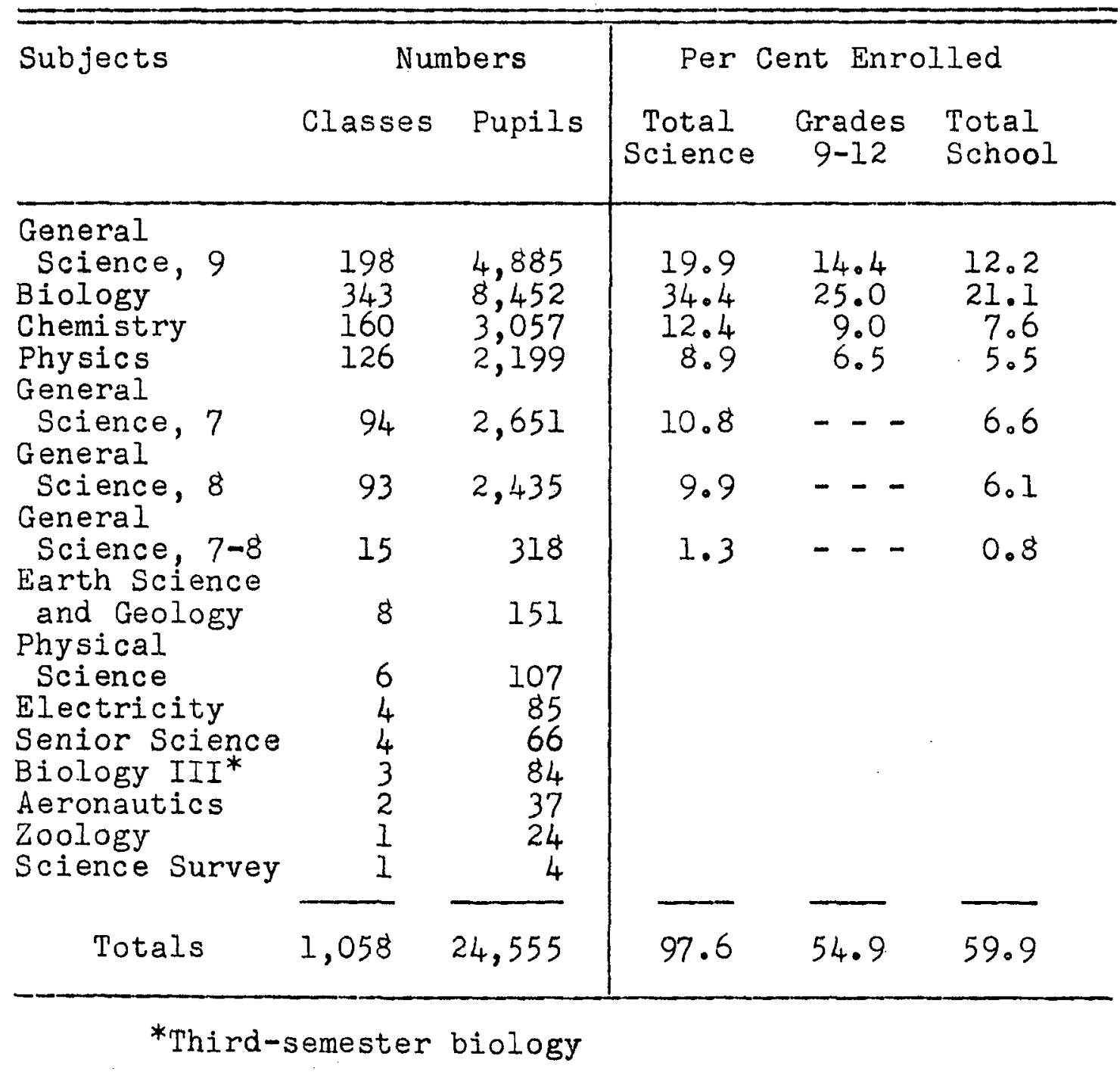


the U.S. Department of Health, Education, and Welfare in 1956, in which they found that 36.2 per cent of all high schools in the couritry were not teaching chemistry and 43.2 per cent of all four-year high schools were not teaching it. 31 These studies have apparently based their estimates of the amount of physical sciences taught on the analysis of only a single year's offerings. Table 10 was inserted into this study to correct this error. Instead of 41 per cent of Montana schools not teaching chemistry, only 9 per cent do not teach it within a two-year period. Instead of 47.4 per cent not teaching physics, in reality only 16.2 per cent do not teach it. Of perhaps even more significance are the figures that relate to pupil enrollment; 98 per cent of Montana high school pupils were able to take chemistry within the two-year period 1957-59, and 96.6 per cent were able to take physics.

Now, how many students are actually enrolled in science classes in these schools? The 1956 U.S. report also gives percentage figures on enroliment in the various sciences. It shows 21.4 per cent of all high school students enrolled in general science. The ivontana enrollment in ninth grade general science was 12.2 per cent of total

31 offerings and Enrollments in Science and Mathematics in Public High Schools: 1956, O.S. Office of Education Pamphlet No. 120, 1957, p. 6。 
school enrollment. For biology the U.S. report gives 20.5 per cent and Table 11 gives 21 per cent for Montana; for chemistry the U.S. report was 7.5 per cent and Montana 7.6 per cent; for physics the U.S. report figure is 4.4 per cent and the Montana figure 5.5 per cent. Lindahi, in a study of chemistry in the Montana high schools, obtained exactly the same figures as this study, or 7.6 per cent. 32

Teaching Assignments

If we accept a tentative working definition of a science teacher as one who teaches more science than nonscience subjects, then of the 431 teachers included in this study 205 can be so classified. Of this number, 62 teach in one science area. Table 12 shows the distribution of these 62 teachers according to subject fields. Since they represent only 30.2 per cent of the 205 we have defined as "science teachers," an undergraduate preparation in one subject area is not very realistic. One other item in Table 12 should also be examined in the light of its significance for teacher training. It should be noted that 31 , or exactly half, of the 62 teachers represented are classified as one-subject teachers in the area of general

${ }^{32}$ Dean M. Lindahl, "A Status Study of Chemistry in Montana Public High Schools," unpublished Master of Arts thesis, Montana State University, 1957, p. 39. 
TABLE 12

NUMBER OF TEACHERS TEACHING FULL TIME IN ONE SCIENCE SUBJECT

\begin{tabular}{lcc}
\hline Subject Field & Number of Teachers & Per Cent \\
\hline General Science & 31 & 50.0 \\
Biology & 20 & 32.3 \\
Chemistry & 7 & 11.3 \\
Physics & 4 & -100.4 \\
Totals & 62 & - \\
\hline
\end{tabular}


science. It probably is not correct to speak of general science as one subject, for it cuts across many fields and therefore requires broad preparation to teach it. This really narrows down to 31 those teaching full time in one science subject.

One-subject teachers are found only in the larger schools, and Table 13 shows their distribution. Since no schools of less than 100 pupils employ full-time one-subject science teachers, and since these smaller schools represent 54.5 per cent of the secondary schools in Montana, employing 36 per cent of the teachers who are teaching science in the state, this distribution has some significance for teacher training.

Fifty-one teachers teach science full time but teach more than one science subject. Table 14 parallels Table 13 to show the distribution of these 51 according to size of school. Thirty-two of them teach in the 100-199 and 300-499 school enrollment groups. At least part of the reason for the disproportionately large number in the 100-199 group is the number of administrators, particularly high school principals, who are teaching science part-time in this category. They are classified with this group because they are full-time employees and are not teaching any other school subjects. The two teacher groups of Tables 13 and 14 total 113 teachers who teach science subjects in all 
TABLE 13

DISTRIBUTION OF ONE-SUBJECT SCIENCE TEACHERS ACCORDING TO SCHOOL SIZE

\begin{tabular}{|c|c|c|}
\hline School Size & Number of Teachers & Per Cent \\
\hline $10-24$ & 0 & -- \\
\hline $25-49$ & 0 & -- \\
\hline $50-74$ & 0 & -- \\
\hline $75-99$ & 0 & -- \\
\hline $100-199$ & 1 & 1.6 \\
\hline $200-299$ & 2 & 3.2 \\
\hline $300-499$ & 2 & 3.2 \\
\hline $500-999$ & 19 & 30.7 \\
\hline $1000-2400$ & 38 & $61 \cdot 3$ \\
\hline Totals & 62 & 100 \\
\hline
\end{tabular}




\section{TABLE 14}

DISTRIBUTION ACCORDING TO SCHOOL SIZE OF SCIENCE TEACHERS TEACHING MORE THAN ONE SCIENCE SUBJECT

\begin{tabular}{lcr}
\hline School Size & Number of Teachers & Per Cent \\
\hline $10-24$ & 0 & - \\
$25-49$ & 0 & 1.9 \\
$50-74$ & 1 & 1.9 \\
$75-99$ & 1 & 31.4 \\
$100-199$ & 16 & 7.9 \\
$200-299$ & 4 & 31.4 \\
$300-499$ & 16 & 9.3 \\
$500-999$ & 5 & 15.7 \\
$1000-2400$ & 8 & 100. \\
Totals & 51 & 16 \\
\hline
\end{tabular}


their classes of the 205 so defined (see page 56).

This leaves 318 of the original 431 who were teaching other subjects than science in 1958-59. However, the picture is not quite as bad as it seems; 111 of this remainder are teaching science and mathematics, a not unusual or objectionable combination from the standpoint of efficient teaching or training. Fifty-nine of these 111 are teaching more mathematics than science.

Science Teachers in Small. Schools Teach More Non-Science Subjects

In the four smallest enrollment groups, teachers assigned to teach science are actually teaching other subjects about two-thirds of their time. A partial analysis of class schedules for all 431 teachers studied is made in Table 15, which shows the number of classes taught in science and non-science areas, according to school size categories. Consideration of this table shows that a very real problem exists with respect to the patterns of teacher training. For example, the fact that only one-third of the teaching load of teachers in smaller schools is science implies that these teachers need to have had more of their undergraduate training in a field or fields outside the sciences, but of course assumes that they have had training for and are qualified to teach science also. 
TABLE 15

DISTRIBUTION OF SCIENCE AND NON-SCIENCE CLASSES FOR ALL TEACHERS STUDIED, ACCORDING TO SCHOOL SIZE

\begin{tabular}{|c|c|c|c|c|c|}
\hline School Size & Teachers & $\begin{array}{l}\text { Number } \\
\text { Science } \\
\text { Classes }\end{array}$ & $\begin{array}{l}\text { Non- } \\
\text { Science } \\
\text { Classes }\end{array}$ & $\begin{array}{l}\text { Per } \\
\text { Science } \\
\text { Classes }\end{array}$ & $\begin{array}{l}\frac{\text { Cent }}{\text { Non- }} \\
\text { Science } \\
\text { Classes }\end{array}$ \\
\hline $10-24$ & 14 & 22 & 44 & 33.3 & 66.7 \\
\hline $25-49$ & 47 & 84 & 152 & 35.6 & 64.4 \\
\hline $50-74$ & 43 & 67 & 136 & 33.0 & 67.0 \\
\hline $75-99$ & 46 & 70 & 117 & 37.4 & 62.6 \\
\hline $100-199$ & 85 & 197 & 193 & 50.5 & 49.5 \\
\hline $200-299$ & 19 & 54 & 21 & 72.0 & 28.0 \\
\hline $300-499$ & 36 & 107 & 42 & 71.8 & 28.2 \\
\hline $500-999$ & 78 & 186 & 81 & 69.7 & 30.3 \\
\hline $1000-2400$ & 63 & 271 & 60 & 81.9 & 18.1 \\
\hline Totals & 431 & 1,058 & 846 & & \\
\hline
\end{tabular}


Under existing conditions of school organization and administrative practices, there is no way for the teacherin-training (or his adviser, for that matter) to foresee all the possible teaching combinations he may be expected and required to undertake. It would be almost impossible, therefore, to devise undergraduate patterns for teacher preparation which would solve this problem. For as long as Montana maintains its many high schools of very small enrollments, where the teacher is expected to be a jack-ofall-trades, this problem will continue to exist. The only solution to it seems to be consolidation, which in turn presents problems which will be discussed later in this study。

Non-Science Subjects Taught by Science Teachers

Mathematics and physical education courses together account for five-eighths (63.2 per cent) of subjects other than science taught by Montana's science teachers. Table 15 lists 846 non-science classes taught by teachers also teaching science classes in 1958-59. Table 16 takes these 846 classes and tabulates them according to subjects; it also shows the distribution of these classes according to the various school size groups.

Concentration is obvious in certain subject areas。 Mathematics leads, with 396 classes being taught by teach- 
TABLE 16

NUMBERS OF CLASSES IN NON-SCITNCE SUBJECTS TAUGHT BY SCIENCE TEACHERS IN 1958-59, ACCORDING TO SCHOOL SIZE

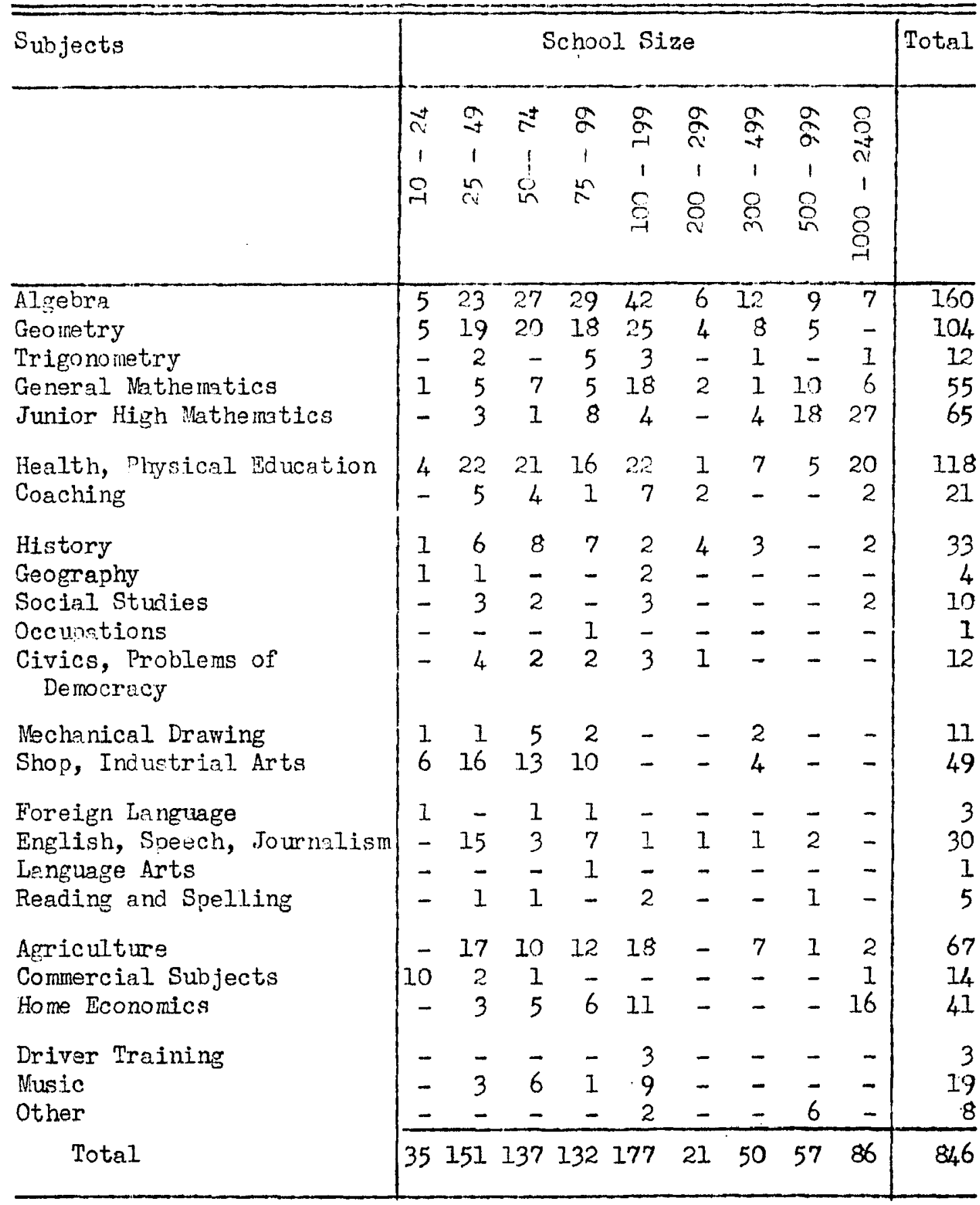


ers also teaching science, or 46.8 per cent of the 846 classes tabulated. Mathematics classes are also well distributed among all school size categories. The physical education field is second, with 139 classes being taught, or 16.4 per cent of the total. Agriculture is third, with 67 classes or 8 per cent. These three fields account for 71.2 per cent of all non-science classes shown on the table. The other areas shown include the social studies field and the industrial arts, both with 60 classes, or 7.1 per cent each; the language arts with 39 classes, or 4.6 per cent; and home economics with 41 classes, or 4.8 per cent. Music, commercial subjects, drivers t training, and "other" account for the remaining 44 classes, or 5.2 per cent. It is interesting to note that almost any high school subject which might be offered is included somewhere in this list, which represents the teaching schedules of those also teaching secondary sciences.

Some facts concerning schedules and teaching combinations which are not shown by this table can be discovered by a more detailed analysis of individual Form $A$ reports. For example, only six of the 118 teachers teaching physical education as well as science teach more physical education than science: in other words, most of them would be classified as "science teachers." Many of the home economics classes listed on Table 16 represent the 
schedules of home economics teachers with a class or two in biology, or possibly chemistry. The Form A reports also show a significant number of teachers-mostly in the smaller schools--who teach as many as four different subjects in perhaps three different subject areas. These latter, if singled out, would appear on Table 16 in several places.

\section{Summary}

Montana's total school population of 116,897 was three-tenths of one per cent of the national enrollment of 41,166,000 in 1958-59. Only 16.9 per cent of Montana's population was enrolled in school, as compared with 24 per cent for the nation as a whole. Of Montana's total enrollment, 40,065 were enrolled in public secondary schools; 33,761 of these were in grades nine through twelve. There are 216 Montana schools classified as secondary schools. Their enrollments range from 10 to over 2000 . of these 216, 190 are public secondary schools; 173 of the 190 are high schools, and 17 are junior high schools, grades seven through nine. The school enrollment-size group which has the largest percentage (26.1) is the 100199 class. In general, the percentages of schools in the various size categories approximate the percentages in the same categories in the nation's schools as a whole. In Montana and in the nation there are more schools in the 
lower five enrollment categories than in the higher five. Montana shows a slightly higher percentage in each of these smaller enrollment groups than the nation as a whole.

There are 84.6 per cent of the nation's high schools and 93.1 per cent of Miontana high schools below the school enrollment which Conant considers desirable. The Montana schools included in this 93.1 per cent enroll 55 per cent of the high school students in the state. One must exercise care in using statistics relating to number of schools and to school enrollment, for it is quite easy to draw erroneous conclusions if, for example, the number of schools is used without at the same time giving the enrollment figures they represent.

Biology is the science subject most frequently taught in Montana high schools. More pupils are also enrolled in it than in any other science subject. Statistics relating to chemistry and physics based on a one-year figure are misleading, for these subjects are alternated in most schools where they are not taught every year. Only five schools in the state, enrolling 164 pupils, or 0.5 per cent of the total enrollment for grades nine through twelve, offer neither chemistry nor physics. Ten schools enrolling 684 , or 2 per cent of the total enrollment, teach no chemistry. Twenty-three schools enrolling 1,159, or 3.4 per cent of the total, teach no physics. 
In 1958-59:

21.1 per cent of the pupils enrolled in grades 9-12 took biology.

12.2 per cent took general science.

7.6 per cent took chemistry.

5.5 per cent took physics.

6.6 per cent of the pupils enrolled in grades

7-12 took seventh grade general science.

6.1 per cent took eighth grade general science.

A total of 431 teachers were included in this study. The criterion for including them was that they be teaching one or more science classes in grades seven through twelve of the public secondary schools of the state in 1958-59. of these teachers, 387 were teaching in grades nine through twelve.

In 1958-59:

205 of the 431 teachers studied taught more science than non-science subjects.

113 of the 205 taught science only.

51 of the 205 taught more than one science subject.

62 of the 205 taught one science subject only。

31 of the 62 taught general science.

Those teachers teaching one subject only are in the upper five enrollment groups, mostly in the upper two cat- 
egories. Of the 318 teachers teaching science and one or more other subjects, 111 taught science and mathematics. Of these, 59 taught more mathematics than science.

There were 846 non-science classes taught by the 431 teachers; 46.8 per cent were mathematics classes, 16.4 per cent were in the area of physical education, and 8 per cent were agriculture classes. Social studies and industrial arts each accounted for 7.1 per cent. Home economics, language arts subjects, music, commercial subjects, other miscellaneous subjects, and drivers training followed in that order. 
CHAPTER IV

PREPARATION OF SCIENCE TEACHERS IN MONTANA

Availability of science courses, enrollment in those courses, the teaching assignment of the teacher are all important, but the first prerequisite of good teaching is knowledge of the material to be taught. Chapter IV deals with the preparation of Montana's science teachers.

Teachers and Quality of Instruction

Relatively f'ew high school students approach the experience of "taking a course in science" with any degree of enthusiasm. The images of science and the scientist which American high school students hold was analyzed in a pilot study by Margaret Mead and Rhoda Metraux. They found:

From the standpoint of teaching, it is important to realize how the present image of scientific work lacks any sense of the delights of intellectual activity. . . One of the most recurrent responses is an expression of active boredom, the phrase,"I am not interested in science," or in a particular

33 Margaret Mead and Rhoda Metraux, "Image of the Scientist among High-School Students," Science, August 30, 1957, p. 389. 
There are, to be sure, some students who are curious about certain science areas. Some even are so enthusiastic that they follow their bent to the neglect of other high school subjects. To the prepared science teacher, these are the gems. To the unprepared teacher, they are intellectual monsters, rearing their heads at unexpected and awkward times. It is highly probable that the number of future scientists have been reduced by poorly prepared teachers.

There are a number of factors which contribute to this lack of enthusiasm for science courses on the part of pupils. Some have heard adverse comments from those who have taken science courses. They shy away from courses in which it seems difficult to succeed; science, they have been told, is "hard." Some pupils find it distasteful to handle snakes, worms, and frogs; to work with nasty-smelling chemicals; to dissect grasshoppers. Finally, pupils too often fear and dislike the austere individual who teaches science.

Barzun, in his Teacher in America, says, "Considered --somewhat unfairly--in the mass, science teachers may be said to contribute the greatest proportion of backwardlooking, anti-intellectual, mechanic-minded members to the faculty." 34 His comments were directed at college teachers. 34 Jacques Barzun, Teacher in America, 1945, p. 82. 
but are too often applicable to high school teachers as well.

In a report published by Harvard University on a conference of nation-wide problems of science teaching, the following generalizations concerning secondary science teachers were submitted:

a) A considerable number of science teachers (particularly in smaller schools) are not certified in science:

b) A significant portion of teachers who are certified to teach in science have relatively meager backgrounds in that area:

c) A fairly large number of science teachers have their science training concentrated in one science area, to the exclusion of other areas:

d) Many teachers certified in science spend all or part of their time teaching non-science classes or engaging in other types of educational activity:

e) Teachers of General Science tend to have less thorough backgrounds than those who teach special subjects:

f) There is a tremendous range both in the scientific and the professional educational backgrounds of the nation's science teachers.35

The quality of instruction in the secondary schools is no doubt partly responsible for the reluctance that pupils have for taking science courses. Too often in-

35 Fletcher Watson, Paul Brandwein, and Sidney Rosen (eds.), Critical Years Ahead in Science Teaching, Report of Conference on Nation-Wide Problems of Science Teaching in the Secondary Schools, Harvard University, 1953, pp. 35-36. 
struction is fragmentary, the fragments seemingly unrelated. The biology teacher in his discussion of the energy cycle fails to relate it to the physical sciences. The physics instructor seldom mentions the biological aspects of energy in his discussions of radiant energy. Both are often incapable of carrying the discussion beyond their own fields because they lack the background knowledge to do so. Few are those in the sciences who are capable of drawing upon the rich field of literature to supplement their teaching。 Even fewer are those who have developed to the fullest an innate skill in teaching, per se--who are, in fact, "born teachers."

It is not the function of this discussion to pursue all the factors which bring about quality instruction, but it must be understood that the factors which we measure quantitatively are not the only ones which are responsible for good teaching. The fact that a teacher has accumulated an imposing number of credits in any one area obviously does not automatically make him a good teacher, nor should the mere accumulation of credits automatically entitle him to a certificate to teach.

It seems pertinent to list at this point some of the factors that make for quality instruction. They fall into three general categories: the teacher, the conditions under which he works, and the students that he teaches。 
Only the first of these three will be discussed here at any length.

Factors included in the second category (teaching conditions) are good administration, availability of adequate teaching facilities in the school, secure personal relationships for the teacher in the community, and a desirable pupil-teacher ratio. It is true, however, that good teaching often can result from the challenge offered by science teaching facilities that are less than optimum。 Some of the factors involved in teaching conditions can be controlled or improved by the teacher himself.

of the three categories that affect the quality of instruction, the one least amenable to change by the individual instructor is the pupil. The teacher must accept his students with whatever learning potential they have inherited and acquired, with such development of that potential as has taken place in their previous educational experience. If he must spend too much time in remedial teaching, he lowers his teaching efficiency in his own area by that much.

No matter how good a teacher is or how well he is prepared, if he is sent into a situation where there is poor administration, inadequate facilities, an unrealistic teaching schedule, and improperly educated pupils, he will never achieve his own best teaching potential. Under these 
conditions, even good teachers would do an unsatisfactory teaching job. However, if the teacher were not well prepared, good teaching would be just as improbable.

What Makes A Good Teacher?

Many characteristics go to make up a good teacher: intelligence; development of his intellectual potential in his own teaching area; enthusiasm for learning; the ability to sift out and dynamically communicate essential information, an ability based upon a thorough knowledge of the learning process and an understanding of young people; the ability to help pupils learn to acquire functional knowledge on their own; and the ability to enrich teaching by drawing liberally from other fields.

These qualifications must be kept in mind in any discussion involving teacher preparation; however, let us emphasize that there is no substitute for knowledge of subject matter. The teacher must know the material which he is attempting to teach, and his knowledge must be far beyond that of his best students.

His undergraduate preparation may not be a completeIy valid criterion by which we can estimate accurately how much subject matter a teacher has; for training beyond graduation, whether formal or informal, may have been even more effective than undergraduate training in some cases. 
Motivation at this level comes from within--it is not superimposed by requirements for graduation in a particular field; the motivation may be provided by the current needs of the teacher, or by his impulses of scholarship, or both. Surely all teachers learn much after they have left the walls of their alma maters, but few are those who accumulate large quantities of subject matter background, sufficiently organized to be of real value, without benefit of formal training.

Until some better method is devised, then, we must depend upon the undergraduate training program to furnish most of the background for the beginning teacher. There are many who recognize the weaknesses of this program in teacher preparation; they realize that too much is attempted in too short a time. This is particularly true in schools where a general education and professional training are crowded into four years. When the four-year college course was instituted many years ago, there was far less actual knowledge to impart than has been accumulated since, particularly in the fields of the sciences. But we still expect that somehow, by some sifting process, we can teach all that was taught years ago plus all that has accumulated since then--in other words, teach all that needs to be taught in just four years' time. Actually we cannot do much more than scratch the surface, if we are attempting to 
provide the science teacher-to-be with a good liberal education, adequate "content" courses in his major and minor teaching fields, and the professional education courses that train him to use his factual knowledge effectively.

Sources and Procedures

This portion of the study is directed at determining how much science and what kinds of science the luontana science teacher has taken in his training program. It is confined chiefly to subject matter preparation, which is amenable to statistical treatment, but it is recognized that a mere listing of courses which the teacher takes during his training period is no real indication of how much he knows about a subject. The way in which subjects were taught, how much the student retained, and how far he went beyond the formal classroom instruction are intangibles which are difficult to evaluate statistically. To get at subject matter preparation, the transcripts of those of the 431 Montana science teachers who took work at the various units of the University of Montana were examined. Transcripts were utilized from all five units which engage in teacher preparation: Montana State University, Montana State College, Eastern Montana College of Education, Northern Montana College, and Western Montana College of Education. Enrollments in these schools in 
1956-57 were 3,$337 ; 4,032 ; 1,110 ; 692$; and 440 , respectively.

In all, 205 transcripts (of the total of 431; see the preceding paragraph) from teachers in various school systems scattered throughout the state were processed and examined; these Montana-trained teachers represent 48.2 per cent of all teachers engaged in science teaching in the state in the year studied. The organization of the tables is similar to that used by Koelsche in a study made in Ohio ${ }^{36}$ and by Pella in a comparable study in Wisconsin. 37 Four science-teaching areas (general science, biology, chemistry, and physics) and four science-preparation areas (biology, chemistry, physics, and geology) form the basis for the discussion which follows.

Differences from the other two studies lie in the use of quarter credit hours instead of semester credit hours and in the elimination of astronomy, health, and mathematics as science subjects included. Koelsche included astronomy in his tabulation. It is absent from this one because of its almost complete absence from the tran-

\section{${ }^{36}$ Charles L. Koelsche, The Academic and Teaching} Backgrounds of Secondary Science Teachers in the State of ohio, University of Toledo, 1958。

37 Nilton 0. Pella, "The Nature of the Academic Preparation in Science of Wisconsin High School Teachers of Physics, Chemistry, Biology, and General Science," Science Education, XLII (March, 1958), 106-137. 
scripts examined; only two teachers showed credits in astronomy. Health and mathematics courses do enrich the background of the science teacher. So do such courses as geography, vocational agriculture, and home economics; but, since some line had to be drawn between what is a science course and what is not, this study has used about the same criterion that most colleges and universities use: would the course be included as part of a major or minor in a natural or physical science? If so, it has been included; if not, it has been omitted. In Ohio, Koelsche studied a sample of 531 science teachers representing 191 high schools. He compiled complete data on 476 of the teachers from 175 of the schools (approximately 18 per cent of the 966 public high schools in Ohio in $1957-58) .38$

Pella's survey was more complete: he tabulated all the high school science teachers in Wisconsin during the period studied and included in his study all for whom he could secure complete data on their college work (including work toward advanced degrees)。 39

The procedure in this portion of the study has been as follows:

$$
\begin{aligned}
& \text { 38 Koelsche, op. cit., p. } 4 . \\
& 39 \text { pella, op. cit., p. } 107 .
\end{aligned}
$$


1. On the basis of the transcripts, all the teachers were sorted into the four teaching areas of general science, biology, chemistry, and physics. (Most of the teachers studied appear in more than one teaching area.)

2. Their backgrounds in biology, chemistry, physics, and geology were examined field by field。 For purposes of tabulation, quarter-credits of college work were arranged by five-credit intervals, from 0 through 56-plus. The same school enrollment-size groups have been used that appear throughout this study。

3. Two summarizing tables were prepared for each teaching area: one showing breadth of preparation of those teaching, and the second showing depth or intensity of preparation.

4. From the tables, two central tendencies were determined. A median was located within a quarter credit interval, and a mean was calculated from those who had taken one or more courses in the area analyzed.

5. The median interval and the mean are compared with Koelsche's and Pella's findings, respectively。

Using these five steps, it has become possible to 
evaluate the preparation of the Montana science teacher in relation to his teaching assignment, and to compare this aspect of science education in Montana with the situation in two other states where similar critical surveys have been made.

\section{General Science Teachers}

Transcripts of 105 teachers who were teaching one or more general science classes were examined; they represent 50.2 per cent of the 209 teachers in Montana teaching some general science in the year studied.

Biology background of general science teachers. Of those teaching general science, 96, or 91.4 per cent, have had one or more courses in biology. There were 8 teachers, or 7.6 per cent of the total, who had as many quarter-credits as a teaching major requires; and 18 more, or 17.1 per cent, had as many hours of biology as teachers with a biology teaching minor. (I have used 56-plus quarter-credits as the number of credits equivalent to a teaching major in biology, and 31 or more credits as equivalent to a teaching minor.) For general science teachers the median number of credits in biology lies in the 21-25 group, and the mean, calculated only from those having had some biology, is 23.6. Table 17 illustrates the above data。

Koelsche found in Ohio that 80 per cent of the 215 general science teachers whose backgrounds he examined had 
TABLE 17

CREDITS EARNED IN BIOLOGY BY GENERAL SCIENCE TEACHERS

\begin{tabular}{|c|c|c|c|c|c|c|c|c|c|c|}
\hline \multirow{2}{*}{$\begin{array}{l}\text { Quarter } \\
\text { Credits }\end{array}$} & \multicolumn{10}{|c|}{ School Size } \\
\hline & $\begin{array}{l}10- \\
24\end{array}$ & $\begin{array}{l}25- \\
49\end{array}$ & $\begin{array}{l}50- \\
74\end{array}$ & $\begin{array}{l}75- \\
99\end{array}$ & $\begin{array}{l}100- \\
199\end{array}$ & $\begin{array}{l}200- \\
299\end{array}$ & $\begin{array}{l}300- \\
499\end{array}$ & $\begin{array}{l}500- \\
999\end{array}$ & $\begin{array}{l}1000- \\
2400\end{array}$ & Total \\
\hline 0 & & & & & 1 & & & 6 & 2 & 9 \\
\hline $1-5$ & & 4 & 1 & & 1 & 1 & 1 & 4 & 3 & 15 \\
\hline $6-10$ & 1 & & & 1 & & & & & 2 & 4 \\
\hline $11-15$ & & & 1 & 1 & 1 & & 1 & 3 & 1 & 8 \\
\hline $16-20$ & & 1 & 2 & 4 & 4 & & 3 & 1 & 4 & 19 \\
\hline $21-25$ & & & 3 & 2 & 4 & 1 & 1 & 1 & 3 & 15 \\
\hline $26-30$ & & & 1 & 1 & 2 & 3 & 2 & 1 & & 10 \\
\hline $31-35$ & & 2 & 1 & 1 & & 1 & & & & 5 \\
\hline $36-40$ & & & 1 & & 1 & & & 2 & & 4 \\
\hline $41-45$ & & & & 1 & 3 & & & 1 & 1 & 6 \\
\hline $46-50$ & & & & & & & 1 & 1 & & 2 \\
\hline $51-55$ & & & & & & & & 1 & & 1 \\
\hline $56+$ & & & & & & & 1 & 4 & 2 & 7 \\
\hline Total & 1 & 7 & 10 & 11 & 17 & 6 & 10 & 25 & 18 & 105 \\
\hline & Media & n 21 & -25 & & & & & & & \\
\hline & Mean & 23.6 & & & & & & & & \\
\hline
\end{tabular}


had biology, and that the median lay in the 26-30 group (after his figures have been translated into quarter-cred1ts). Pella found that 86.2 per cent of the 351 Wisconsin teachers he studied had had some preparation in biology. He found a mean of 22.6 quarter-credits (when transposed from equivalent semester credits).

General science teachers in Montana are reasonably well prepared in biology; nearly two-thirds of them have had more than a year of background preparation. The concentration of those who have had little or no biology in the larger schools is accounted for by the fact that these teachers are teaching junior high general science as a second or even a third subject. Their major preparation has been in fields other than science--a situation that needs remedying and to which further reference will be made. It is noteworthy that the general science teachers with the greatest amount of biology are also in the larger schools; they are teachers of biology who also teach general science. The junior high teacher usually is teaching a combination of general science and a non-science field.

\section{Chemistry background of general science teachers.}

The preparation of general science teachers in chemistry is shown in Table 18. Where only nine had no preparation in biology, 27 show no credit for courses in chemistry. The 
TABLE 18

CREDITS EARNED IN CHEMISTRY BY GENERAL SCIENCE TEACHERS

\begin{tabular}{|c|c|c|c|c|c|c|c|c|c|c|}
\hline \multirow{2}{*}{$\begin{array}{l}\text { Quarter } \\
\text { Credits }\end{array}$} & \multicolumn{10}{|c|}{ School Size } \\
\hline & $\begin{array}{l}10- \\
24\end{array}$ & $\begin{array}{l}25- \\
49\end{array}$ & $\begin{array}{l}50- \\
74\end{array}$ & $\begin{array}{l}75- \\
99\end{array}$ & $\begin{array}{l}100- \\
199\end{array}$ & $\begin{array}{l}200- \\
299\end{array}$ & $\begin{array}{l}300- \\
499\end{array}$ & $\begin{array}{l}500- \\
999\end{array}$ & $\begin{array}{l}1000- \\
2400\end{array}$ & Total \\
\hline 0 & 1 & 3 & 2 & & 4 & 2 & 4 & 7 & 4 & 27 \\
\hline $1-5$ & & & 1 & & 4 & & & 1 & 1 & 7 \\
\hline $6-10$ & & 1 & 3 & 2 & & 2 & & 4 & 3 & 15 \\
\hline $11-15$ & & 2 & 2 & 4 & 5 & 1 & 3 & 7 & 3 & 27 \\
\hline $16-20$ & & & & 2 & 1 & & 1 & 2 & 3 & 9 \\
\hline $21-25$ & & & 1 & & 1 & & 1 & 1 & 2 & 6 \\
\hline $26-30$ & & 1 & & 2 & 2 & & & 3 & 1 & 9 \\
\hline $31-35$ & & & 1 & 1 & & 1 & & & & 3 \\
\hline $36-40$ & & & & & & & 1 & & & 1 \\
\hline \multicolumn{11}{|l|}{$41-45$} \\
\hline \multicolumn{11}{|l|}{$46-50$} \\
\hline $51-55$ & & & & & & & & & 1 & 1 \\
\hline \multicolumn{11}{|l|}{$56+$} \\
\hline Total & 1 & 7 & 10 & 11 & 17 & 6 & 10 & 25 & 18 & 105 \\
\hline \multicolumn{11}{|c|}{ Median $11-15$} \\
\hline & Mean & 15.8 & & & & & & & & \\
\hline
\end{tabular}


number who had had one or more courses is 78 , which represents 74.3 per cent of those who teach general science. The median number of credits lies in the $11-15$ group; the mean for all those taking chemistry is 15.8 quarter-hours. None of those teaching general science had enough credits for a chemistry teaching major, and only five teachers, or 4.8 per cent, had enough for a teaching minor.

In his Ohio study, Koelsche found that 71.6 per cent of the general science teachers examined had taken some chemistry, and that the median number of quarter-credits lay in the 21-25 interval. Pella reported that 87.7 per cent of the Wisconsin general science teachers had had chemistry, with a mean of 21.5 credit hours. Montana general science teachers show fewer hours of chemistry than either Wisconsin or Ohio teachers. The percentage who have had some chemistry lies between the percentages of the other two studies. It is of interest to note the shift toward less credit hours, when comparing preparation in biology with preparation in chemistry. It is also interesting to see that the 27 who had no preparation at all in chemistry are quite evenly scattered among the various school size groups.

\section{Physics background of general science teachers.}

Table 19 shows the preparation of this same general science 
TABLE 19

CREDITS EARNED IN PHYSICS BY GENERAL SCIENCE TEACHERS

\begin{tabular}{|c|c|c|c|c|c|c|c|c|c|c|}
\hline \multirow{2}{*}{$\begin{array}{l}\text { Quarter } \\
\text { Credits }\end{array}$} & \multicolumn{10}{|c|}{ School Size } \\
\hline & $\begin{array}{l}70- \\
24\end{array}$ & $\begin{array}{l}25- \\
49\end{array}$ & $\begin{array}{l}50- \\
74\end{array}$ & $\begin{array}{l}75- \\
99\end{array}$ & $\begin{array}{l}100- \\
199\end{array}$ & $\begin{array}{l}200- \\
299\end{array}$ & $\begin{array}{l}300- \\
499\end{array}$ & $\begin{array}{l}500- \\
999\end{array}$ & $\begin{array}{l}1000- \\
2400\end{array}$ & Total \\
\hline 0 & 1 & 2 & 6 & 3 & 8 & 3 & 3 & 8 & 4 & 38 \\
\hline $1-5$ & & & 1 & 2 & 2 & 2 & 4 & 3 & 3 & 1.7 \\
\hline $6-10$ & & 2 & 2 & 3 & 4 & & 2 & 5 & 2 & 20 \\
\hline $11-15$ & & 2 & 1 & 3 & 2 & 1 & 1 & 7 & 8 & 25 \\
\hline $16-20$ & & 1 & & & 1 & & & 1 & & 3 \\
\hline $21-25$ & & & & & & & & 1 & & 1 \\
\hline \multicolumn{11}{|l|}{$26-30$} \\
\hline \multicolumn{11}{|l|}{$31-35$} \\
\hline \multicolumn{11}{|l|}{$36-40$} \\
\hline \multicolumn{11}{|l|}{$41-45$} \\
\hline \multicolumn{11}{|l|}{$46-50$} \\
\hline \multicolumn{11}{|l|}{$51-55$} \\
\hline \multicolumn{11}{|l|}{$56+$} \\
\hline Total & 1 & 7 & 10 & 11 & 17 & 6 & 10 & 25 & 18 & 105 \\
\hline & Medis & n 6. & & & & & & & & \\
\hline & Mean & 10.0 & & & & & & & & \\
\hline
\end{tabular}


group in physics. The percentage who had taken one or more courses in physics is 63.8 , compared to the 74.3 per cent who had taken chemistry. (See Table 18.) This is to be expected, for most studies show that physics preparation is the weakest of the three major areas. The median of the Montana study lies in the 6-10 interval, with a mean of 10.0 credits for those taking some physics. There were 38 general science teachers, or 36.2 per cent of those studied, with no physics in their transcripts.

In Ohio, Koelsche found that 61 per cent had had some physics, with a median in the 1l-1.5 interval. Fella reported 76.2 per cent showing some preparation in physics, with an average of 17.3 credits. Ijone of the Montana teachers in this group had sufficient credits in physics for even a teaching minor. The data in Table 19 indicate that Montana general science teachers are lacking in training in physics. Both Ohio and Wisconsin teachers show better preparation in physics, but all three studies show definite lack of teacher preparation in this area.

Four factors are largely responsible for this deficiency. First, physics is a difficult subject and for various reasons does not appeal to many individuals. Second, a good grounding in mathematics is necessary for college physics beyond the most elementary courses. Calculus is a prerequisite for any except beginning courses, 
and not many prospective teachers have the time to fit that much mathematics into their schedules, particularly if they are preparing to teach general science. Third, physics students with more than an elementary knowledge of the subject are not often encouraged by their college physics instructors to become high school teachers. This attitude on the part of the college instructor is understandable, when teaching careers and careers in the field of pure or applied science are compared. At present, high school teaching suffers by comparison in almost every respect. Finally, few college physics departments have made any attempt to "tailor" courses for the training of teachers.

Since we live in an age largely governed by applied physics, it is mandatory that we take steps to see that our science teachers are better grounded in the subject than evidence indicates they now are. It is particularly important that general science teachers have some training in and understanding of physics, because for most secondary students basic understanding of the physical world must come in general science classes, if at all--most of them will never take high school physics. The general science teacher is responsible for their education in this area.

\section{Geology background of general science teachers.}

General science teachers are even more deficient in geology 
than in physics. Only 43.8 per cent of Montana's general science teachers surveyed had any geology, and then only a smattering. (See Table 20.) The median lies in the 1-5 quarter-credit interval. The mean number of hours credit of those who had taken any geology is only 4.8 --less than an average course of work for one quarter. Only one teacher had more than 15 hours, and 59 teachers had no geology at all.

The Ohio and Wisconsin studies show comparable figures. Koelsche reported 43 per cent as having had geology and found his median to lie in the 6-10 interval. Pella found 55.8 per cent, with a mean of 9 credits. (It is important to remember that the means calculated in the Montana and the Wisconsin studies exclude all those with no credits in the science subject being considered.)

If one of the functions of a science teacher is to interpret the environment, it would appear that relatively few are capable of doing so. In Montana, much of whose economy is based on such primary industries as mining, a knowledge of geology is particularly desirable; and since a basic understanding of geology is also helpful in understanding natural resource management, geology should be part of the preparation of the general science teacher。 Furthermore, a knowledge of historical geology is necessary for a complete understanding of life sciences. 
TABLE 20

CREDITS EARNED IN GEOLOGY BY GENERAL SCIENCE TEACHERS

\begin{tabular}{|c|c|c|c|c|c|c|c|c|c|c|}
\hline \multirow{2}{*}{$\begin{array}{l}\text { Quarter } \\
\text { Credits }\end{array}$} & \multicolumn{10}{|c|}{ School Size } \\
\hline & $\begin{array}{l}\overline{10-} \\
24\end{array}$ & $\begin{array}{l}25- \\
49\end{array}$ & $\begin{array}{l}50- \\
74\end{array}$ & $\begin{array}{l}75- \\
99\end{array}$ & $\begin{array}{l}100- \\
199\end{array}$ & $\begin{array}{l}200- \\
299\end{array}$ & $\begin{array}{l}300- \\
499\end{array}$ & $\begin{array}{l}500- \\
999\end{array}$ & $\begin{array}{l}1000- \\
2400\end{array}$ & Total \\
\hline 0 & 1 & 6 & 5 & 8 & 6 & 3 & 4 & 16 & 10 & 59 \\
\hline $1-5$ & & & 5 & 2 & 9 & 3 & 5 & 4 & 6 & 34 \\
\hline $6-10$ & & 1 & & 1 & 2 & & 1 & 1 & 2 & 8 \\
\hline $11-1.5$ & & & & & & & & 3 & & 3 \\
\hline $16-20$ & & & & & & & & 1 & & 1 \\
\hline \multicolumn{11}{|l|}{$21-25$} \\
\hline \multicolumn{11}{|l|}{$26-30$} \\
\hline \multicolumn{11}{|l|}{$31-35$} \\
\hline \multicolumn{11}{|l|}{$36-40$} \\
\hline \multicolumn{11}{|l|}{$41-45$} \\
\hline \multicolumn{11}{|l|}{$46-50$} \\
\hline \multicolumn{11}{|l|}{$51-55$} \\
\hline \multicolumn{11}{|l|}{$56+$} \\
\hline Total & 1 & 7 & 10 & 11 & 17 & 6 & 10 & 25 & 18 & 105 \\
\hline & Media & n 1. & & & & & & & & \\
\hline & Mean & 4.8 & & & & & & & & \\
\hline
\end{tabular}


Total science background of general science teachers.

Table 21, which summarizes the total number of science credits earned by general science teachers studied, shows that 101 of the 105, or 96.2 per cent, have had some science training. The median for all lies in the $41-45$ interval; the mean is 45.2 credit-hours. Koelsche's median was slightly higher--the 51-55 group; Pella found an even higher median--the 56-60 interval, with a mean of 57.7 credits in science per teacher. (This latter total, of course, included credits earned in health and in mathematics.) It would appear that Montana teachers of general science suffer slightly by comparison. Not quite twothirds had 31 or more credits, while three-fourths of the Ohio and Wisconsin teachers studied had a total of 31 or more credits.

In breadth of preparation those general science teachers whose transcripts were examined seem to do very well. There were 67.6 per cent who had preparation in more than two areas, and more than 25 per cent had preparation in all four areas. These facts are shown in Table 22, which shows the numbers of broad areas in which these teachers show preparation. Koelsche's Ohio study showed that 47.4 per cent of the 215 general science teachers he investigated had preparation in more than two science areas. on the whole, general science teachers need broader 
TABLE 21

TOTAL SCIENCE CREDITS EARNED BY GENERAL SCIENCE TEACHERS

\begin{tabular}{|c|c|c|c|c|c|c|c|c|c|c|}
\hline \multirow{2}{*}{$\begin{array}{l}\text { Quarter } \\
\text { Credits }\end{array}$} & \multicolumn{10}{|c|}{ School Size } \\
\hline & $\begin{array}{l}10- \\
24\end{array}$ & $\begin{array}{l}25- \\
49\end{array}$ & $\begin{array}{l}50- \\
74\end{array}$ & $\begin{array}{l}75- \\
99\end{array}$ & $\begin{array}{l}100- \\
199\end{array}$ & $\begin{array}{l}200- \\
299\end{array}$ & $\begin{array}{l}300- \\
499\end{array}$ & $\begin{array}{l}500- \\
999\end{array}$ & $\begin{array}{l}1000- \\
2400\end{array}$ & - Total \\
\hline $\begin{array}{l}0 \\
1-5 \\
6-10 \\
11-15 \\
16-20 \\
21-25 \\
26-30 \\
31-35 \\
36-40 \\
41-45 \\
46-50 \\
51-55 \\
56-60 \\
61-65 \\
66-70 \\
71-75 \\
76-80 \\
81-85 \\
86-90 \\
91-95 \\
96-100 \\
\text { over } 100\end{array}$ & Dy & $\begin{array}{l}1 \\
1 \\
1 \\
2 \\
1\end{array}$ & $\begin{array}{l}1 \\
2 \\
2 \\
2 \\
1 \\
1\end{array}$ & $\begin{array}{l}1 \\
1 \\
2 \\
1 \\
1 \\
1 \\
2\end{array}$ & $\begin{array}{l}2 \\
1 \\
1 \\
2 \\
1 \\
\\
2 \\
2 \\
1 \\
4\end{array}$ & $\begin{array}{l}1 \\
1 \\
1 \\
1\end{array}$ & $\begin{array}{l}1 \\
1 \\
2 \\
1 \\
2 \\
1 \\
1\end{array}$ & $\begin{array}{l}2 \\
\\
4 \\
1 \\
1 \\
3 \\
1 \\
2 \\
1\end{array}$ & $\begin{array}{l}1 \\
1 \\
1 \\
1 \\
1 \\
2 \\
1 \\
1 \\
1 \\
1\end{array}$ & $\begin{array}{r}4 \\
3 \\
3 \\
12 \\
5 \\
3 \\
4 \\
11 \\
9 \\
7 \\
4 \\
5 \\
7 \\
7 \\
4 \\
7 \\
2 \\
1 \\
2 \\
1 \\
4\end{array}$ \\
\hline Total & 1 & 7 & 10 & 11 & 17 & 6 & 10 & 25 & 18 & 105 \\
\hline
\end{tabular}

Median $4.2-45$

Mean 45.2 


\section{TABLE 22}

NUNBER OF SCIENCE AREAS IN WHICH GENERAL SCIENCE TEACHERS RECEIVED CREDIT

\begin{tabular}{|c|c|c|c|c|c|c|c|c|c|c|c|}
\hline \multirow[t]{2}{*}{ Number of Areas } & \multicolumn{9}{|c|}{ School Size } & \multirow{2}{*}{$\begin{array}{l}\text { Per } \\
\text { Cent }\end{array}$} & \multirow[t]{2}{*}{ Total } \\
\hline & $\begin{array}{l}10- \\
24\end{array}$ & $\begin{array}{l}25- \\
49\end{array}$ & $\begin{array}{l}50- \\
74\end{array}$ & $\begin{array}{l}75- \\
99\end{array}$ & $\begin{array}{l}100- \\
199\end{array}$ & $\begin{array}{l}200- \\
299\end{array}$ & $\begin{array}{l}300- \\
499\end{array}$ & $\begin{array}{l}500- \\
999\end{array}$ & $\begin{array}{l}1000- \\
2400\end{array}$ & & \\
\hline None & & & & & & & & 2 & & 1.9 & 2 \\
\hline One & 1 & 1 & 1 & & 3 & 2 & & 3 & 2 & 12.4 & 13 \\
\hline Two & & 1 & 1 & 2 & 3 & 2 & 3 & 5 & 2 & 18.1 & 19 \\
\hline Three & & 4 & 6 & 7 & 5 & & 4 & 7 & 9 & 40.0 & 42 \\
\hline Four & & 1 & 2 & 2 & 6 & 2 & 3 & 8 & 5 & 27.6 & 29 \\
\hline - Total & 1 & 7 & 10 & 11 & 17 & 6 & 10 & 25 & 18 & 100. & 105 \\
\hline
\end{tabular}


preparation than do other science teachers, but indicated breadth may be no more than fragmented background if it is not combined with some depth. Since depth is not possible in all areas, most authorities advocate some depth in one area with sufficient work in other areas to support it. In the case of general science teachers, the need for breadth may not permit preparation in any one soience area to equal. the minimum in hours needed for a teaching major.

\section{Biology Teachers}

Transcripts of 93 science teachers who were teaching one or more classes in biology were examined. These Montana-trained teachers represent 49.7 per cent of the 187 who were teaching some biology classes in ivontana secondary schools in the year surveyed. All but one biology teacher had some courses in biology (see Table 23), and thus it can be said that 98.9 per cent have had some background in their subject.

\section{Biology background of biology teachers. Since biol-} ogy cuts across several specialized disciplines within the field, it is necessary to be specific about the courses that have been considered biology courses. Credits in zoology, botany, physiology, anatomy, microbiology, and bacteriology were considered biological subjects and were tabulated as such. No methods courses, or courses in such 
TABLE 23

CREDITS EARNED IN BIOLOGY BY BIOLOGY TEACHERS

\begin{tabular}{|c|c|c|c|c|c|c|c|c|c|c|}
\hline \multirow{2}{*}{$\begin{array}{l}\text { Quarter } \\
\text { Credits }\end{array}$} & \multicolumn{10}{|c|}{ School Size } \\
\hline & $\begin{array}{l}10- \\
24\end{array}$ & $\begin{array}{l}25- \\
49\end{array}$ & $\begin{array}{l}50- \\
74\end{array}$ & $\begin{array}{l}75- \\
99\end{array}$ & $\begin{array}{l}100- \\
199\end{array}$ & $\begin{array}{l}200- \\
299\end{array}$ & $\begin{array}{l}300- \\
499\end{array}$ & $\begin{array}{l}500- \\
999\end{array}$ & $\begin{array}{l}1000- \\
2400\end{array}$ & Total \\
\hline 0 & & & & & & & & & 1 & 1 \\
\hline $1-5$ & & 1 & & & & & & 2 & & 3 \\
\hline $6-10$ & 1 & & & 1 & & & I. & & & 3 \\
\hline $11-15$ & & 3 & 3 & & 2 & 1 & 1 & & 1 & 11 \\
\hline $16-20$ & 1 & 2 & 3 & 1 & 3 & & 1 & $I$ & 1 & 13 \\
\hline $21-25$ & & & 4 & 4 & 7 & 1 & & & 1 & 17 \\
\hline $26-30$ & & 1 & 2 & 1 & 4 & 2 & & & & 10 \\
\hline $31-35$ & & 1 & 2 & 2 & 2 & & & & & 7 \\
\hline $36-40$ & & & 1 & & 1 & 1 & 1 & & & 4 \\
\hline $41-45$ & & & & 2 & 3 & & & & 3 & 8 \\
\hline $46-50$ & & & & & 1 & 1 & & & 1 & 3 \\
\hline $51-55$ & & & 1 & & & & 2 & $\therefore$ & & 3 \\
\hline $56+$ & & 1. & & & 1 & & 2 & 3 & 3 & 10 \\
\hline Total & 2 & 9 & 16 & 11 & 24 & 6 & 8 & 6 & 11 & 93 \\
\hline & Mediar & n 21 & -25 & & & & & & & \\
\hline & Mean & 29.2 & & & & & & & & \\
\hline & Per c & ent $t$ & aking & biol & & 98.9 & & & & \\
\hline
\end{tabular}


applied sciences as forestry or agriculture, were included. The median number of hours taken falls in the 21-25 interval, and the mean calculated is 29.2; Koelsche found that 97.1 per cent of the 240 biology teachers he studied had had some biology, and Pella found that 97.8 per cent of 367 biology teachers had had some college preparation in the subject. The median in Koelsche's Ohio study was in the 36-40 interval, and the mean of Pella's Wisconsin study was 30.7 credit hours. A trend line drawn through Table 23 from the upper left to the lower right would show a positive correlation between size of school and amount of teacher preparation.

Chemistry background of biology teachers. Of the same 93 biology teachers, 87.1 per cent had had some college work in chemistry. (See Table 24.) The median lies in the 11-15 interval, and the mean number of hours of those who had had any chemistry is 15.6. Koelsche found that 51 per cent had taken some chemistry; his median was located in the 16-20 interval. Pella found that 79.8 per cent had had some chemistry; his mean was 20 credits.

The median of 11-15 credits found in this study indicates that the average Montana biology teacher has had about one year of college chemistry. This means that he has had no courses in quantitative analysis, organic chem- 
TABLE 24

CREDITS EARNED IN CHEMISTRY BY BIOLOGY TEACHERS

\begin{tabular}{|c|c|c|c|c|c|c|c|c|c|c|}
\hline \multirow{2}{*}{$\begin{array}{l}\text { Quarter } \\
\text { Credits }\end{array}$} & \multicolumn{10}{|c|}{ School Size } \\
\hline & $\begin{array}{l}10- \\
24\end{array}$ & $\begin{array}{l}25- \\
49\end{array}$ & $\begin{array}{l}50- \\
74\end{array}$ & $\begin{array}{l}75- \\
99\end{array}$ & $\begin{array}{l}100- \\
199\end{array}$ & $\begin{array}{l}200- \\
299\end{array}$ & $\begin{array}{l}300- \\
499\end{array}$ & $\begin{array}{l}500- \\
999\end{array}$ & $\begin{array}{l}1000- \\
2400\end{array}$ & Total \\
\hline 0 & 1 & 1 & 2 & 2 & 1 & 3 & 1 & & 1 & 12 \\
\hline $1-5$ & & & & & 4 & 1 & & 1 & & 6 \\
\hline $6-10$ & 1 & 3 & 6 & 1 & 2 & 1 & 1 & & 1 & 16 \\
\hline $11-15$ & & 4 & 4 & 5 & 6 & & 3 & 1 & 6 & 29 \\
\hline $16-20$ & & & 2 & 1 & 2 & & 1 & 1 & & 7 \\
\hline $21-25$ & & & 2 & & 4 & & 2 & & 1 & 9 \\
\hline $26-30$ & & 1 & & 2 & 3 & & & 3 & 2 & 11 \\
\hline $31-35$ & & & & & 1 & 1 & & & & 2 \\
\hline $36-40$ & & & & & 1 & & & & & 1 \\
\hline \multicolumn{11}{|l|}{$41-45$} \\
\hline \multicolumn{11}{|l|}{$46-50$} \\
\hline \multicolumn{11}{|l|}{$51-55$} \\
\hline \multicolumn{11}{|l|}{$56+$} \\
\hline Total & 2 & 9 & 16 & 11 & 24 & 6 & 8 & 6 & 11 & 93 \\
\hline \multicolumn{11}{|c|}{ Median $11-15$} \\
\hline & Mean & 15.6 & & & & & & & & \\
\hline & Per $c$ & ent $t$ & aking & chem & istry & 87.1 & & & & \\
\hline
\end{tabular}


istry, biochemistry, or physiological chemistry. Training in these three areas of chemistry is necessary for anything beyond a superficial knowledge of life processes; and as the elementary schools step up their science programs, it will be necessary for the high school biology teacher to deepen his treatment of the subject if he is to challenge future high school students. This he can do only if his own preparation is adequate.

Physics background of biology teachers. Roughly two-thirds, or 67.7 per cent, of the biology teachers examined had some hours in physics. (See Table 25.) The median number of hours taken lies in the 6-10 interval, with a mean of 9.7 credits. Koelsche found that only 32 per cent of Ohio biology teachers had had any physics; the median number of hours they had taken lay in the 11-15 interval. Pella found that 59.4 per cent of Wisconsin's biology teachers had taken physics, with a mean of 14.9 hours.

Physics, while not so obviously related to biology as chemistry is, nevertheless is important as a background subject. Experience in precision measurement, the physical aspects of the energy cycle, training in building and manipulating physical equipment, and finally, sufficient background to accept the most recent challenge given to 
TABLE 25

CREDITS - EARNED IN PHYSICS BY BIOLOGY TEACHERS

\begin{tabular}{|c|c|c|c|c|c|c|c|c|c|c|}
\hline \multirow{2}{*}{$\begin{array}{l}\text { Quarter } \\
\text { Credits }\end{array}$} & \multicolumn{10}{|c|}{ School Size } \\
\hline & $\begin{array}{l}10- \\
24\end{array}$ & $\begin{array}{l}25- \\
49\end{array}$ & $\begin{array}{l}50- \\
74\end{array}$ & $\begin{array}{l}75- \\
99\end{array}$ & $\begin{array}{l}100- \\
199\end{array}$ & $\begin{array}{l}200- \\
299\end{array}$ & $\begin{array}{l}300- \\
499\end{array}$ & $\begin{array}{l}500- \\
999\end{array}$ & $\begin{array}{l}1000- \\
2400\end{array}$ & Total \\
\hline 0 & 1 & 2 & 7 & 3 & 4 & 5 & 2 & 2 & 4 & 30 \\
\hline $1-5$ & & & 3 & & 7 & & & & & 10 \\
\hline $6-10$ & 1 & 4 & 4 & 5 & 7 & & 3 & 2 & 5 & 31 \\
\hline $11-15$ & & 3 & 1 & 3 & 5 & 1 & 3 & 1 & 2 & 19 \\
\hline $16-20$ & & & & & 1 & & & & & 1 \\
\hline $21-25$ & & & 1 & & & & & 1 & & 2 \\
\hline \multicolumn{11}{|l|}{$26-30$} \\
\hline \multicolumn{11}{|l|}{$3 I-35$} \\
\hline \multicolumn{11}{|l|}{$36-40$} \\
\hline \multicolumn{11}{|l|}{$41-45$} \\
\hline \multicolumn{11}{|l|}{$46-50$} \\
\hline \multicolumn{11}{|l|}{$51-55$} \\
\hline \multicolumn{11}{|l|}{$56+$} \\
\hline Total & 2 & 9 & 16 & 11 & 24 & 6 & 8 & 6 & 11 & 93 \\
\hline & Vedia: & $6-$ & & & & & & & & \\
\hline & Mean & 9.7 & & & & & & & & \\
\hline
\end{tabular}


the biology teacher--the implications for biology of radiation phenomena--are all important. Table 25 shows that our biology teachers are in general ill-equipped.

Geology background of biology teachers. In the area of earth science or geology, only 28 , or 30.1 per cent, of the 93 biology teachers showed any preparation. Most of the 28 apparently had had one quarter's course, for $1-5$ credits; the mean was 4.6 credits. This is, or should be, surprising, for earth science is more closely related to biology than is physics.

In Ohio Koelsche found only about half as many in proportion who had taken any geology, or 16.7 per cent of the biology teachers he studied; Pella found about twice as many in his Wisconsin study, or 60.8 per cent. Koelsche's median interval was 6-10; Pella's mean was 10 credits.

With the increased emphasis on ecology in the field of biology, it is essential that the biology teacher have some knowledge of geology; for even a superficial understanding of the basic concepts in natural resource management, some knowledge of geology is also necessary. Since many of our young people get most of their formal education concerning natural resources in the biology classroom, the biology teacher needs sufficient background to interpret this area. Table 26 shows the meagerness of his training. 
TABLE 26

CREDITS EARNED IN GEOLOGY BY BIOLOGY TEACHERS

\begin{tabular}{|c|c|c|c|c|c|c|c|c|c|c|}
\hline \multirow{2}{*}{$\begin{array}{l}\text { Quarter } \\
\text { Credits }\end{array}$} & \multicolumn{10}{|c|}{ School Size } \\
\hline & $\begin{array}{l}10- \\
24\end{array}$ & $\begin{array}{l}25- \\
49\end{array}$ & $\begin{array}{l}50- \\
74\end{array}$ & $\begin{array}{l}75- \\
99\end{array}$ & $\begin{array}{l}100- \\
199\end{array}$ & $\begin{array}{l}200- \\
299\end{array}$ & $\begin{array}{l}300- \\
499\end{array}$ & $\begin{array}{l}500- \\
999\end{array}$ & $\begin{array}{l}1000- \\
2400\end{array}$ & Total \\
\hline 0 & 1 & 6 & 10 & 10 & 17 & 5 & 4 & 4 & 8 & 65 \\
\hline $1-5$ & & 3 & 4 & 1 & 4 & 1 & 2 & 2 & 3 & 20 \\
\hline $6-10$ & 1 & & 2 & & 3 & & 1 & & & 7 \\
\hline $11-15$ & & & & & & & 1 & & & 1 \\
\hline \multicolumn{11}{|l|}{$16-20$} \\
\hline \multicolumn{11}{|l|}{$21-25$} \\
\hline \multicolumn{11}{|l|}{$26-30$} \\
\hline \multicolumn{11}{|l|}{$31-35$} \\
\hline \multicolumn{11}{|l|}{$36-40$} \\
\hline \multicolumn{11}{|l|}{$41-45$} \\
\hline \multicolumn{11}{|l|}{$46-50$} \\
\hline \multicolumn{11}{|l|}{$51-55$} \\
\hline \multicolumn{11}{|l|}{$56+$} \\
\hline Total & 2 & 9 & 16 & 11 & 24 & 6 & 8 & 6 & 11 & 93 \\
\hline & Iedia. & $1-$ & & & & & & & & \\
\hline & Iean & 4.6 & & & & & & & & \\
\hline
\end{tabular}


Total science background of biology teachers. Table 27 summarizes the science credits of biology teachers; the median number of credits in all science areas lies in the 51-55 interval. The mean is found to be 54.6. Koelsche's median for biology teachers lay in the 46-50 interval. Pella found the median in the 61-65 interval, with a mean of 62 credits.

Breadth of preparation of these ivontana biology teachers is indicated in Table 28. There are 69.9 per cent who have had training in at least three science areas, 19.3 per cent with training in two areas, and 9.7 per cent with training in just one area. The single teacher with no science training at all represents 1.1 per cent of the total. Koelsche, who tabulated similar information for his comparable group, found that approximately 44 per cent had had preparation in one area, 21 per cent in two areas, 24 per cent in three areas, and 8.7 per cent in four areas. Koelsche, of course, had tabulated astronomy, which he represented as a fifth area on his table showing breadth of training. His extremes were 1.7 per cent with training in all five areas listed, and 1.3 per cent with no science training at all.

The transcripts indicated that although practically all Montana teachers of biology had had some biology training, the average number of hours of preparation was not as 
TABLE 27

TOTAL SCIENCE CREDITS EARNED BY BIOLOGY TEACHERS

\begin{tabular}{|c|c|c|c|c|c|c|c|c|c|c|}
\hline \multirow{2}{*}{$\begin{array}{l}\text { Quarter } \\
\text { Credits }\end{array}$} & \multicolumn{10}{|c|}{ School Size } \\
\hline & $\begin{array}{l}10- \\
24\end{array}$ & $\begin{array}{l}25- \\
49\end{array}$ & $\begin{array}{l}50- \\
74\end{array}$ & $\begin{array}{l}75- \\
99\end{array}$ & $\begin{array}{l}100- \\
199\end{array}$ & $\begin{array}{l}200- \\
299\end{array}$ & $\begin{array}{l}300- \\
499\end{array}$ & $\begin{array}{l}500- \\
999\end{array}$ & $\begin{array}{l}1000- \\
2400\end{array}$ & Total \\
\hline \multirow{10}{*}{$\begin{array}{l}0 \\
1-5 \\
6-10 \\
11-15 \\
15-20 \\
21-25 \\
26-30 \\
31-35 \\
36-40 \\
41-45 \\
46-50 \\
51-55 \\
56-60 \\
61-65 \\
66-70 \\
71-75 \\
76-80 \\
81-85 \\
86-90 \\
91-95 \\
96-1.00 \\
\text { over } 100\end{array}$} & & & & & & & & & 1 & 1 \\
\hline & 1. & & & & & 1 & & & & $\frac{1}{1}$ \\
\hline & & & & $\begin{array}{l}1 \\
1\end{array}$ & & & & & 1 & $\begin{array}{l}3 \\
2\end{array}$ \\
\hline & & 1 & 2 & & 1 & 1 & & 1 & & 6 \\
\hline & & $\begin{array}{l}1 \\
1\end{array}$ & $\begin{array}{l}3 \\
1\end{array}$ & 2 & $\begin{array}{l}2 \\
2\end{array}$ & 1 & $\begin{array}{l}2 \\
1\end{array}$ & 1 & & $\begin{array}{l}9 \\
8\end{array}$ \\
\hline & $I$ & 2 & $\frac{1}{3}$ & & & $\begin{array}{l}1 \\
1\end{array}$ & & & 1 & $\begin{array}{l}9 \\
6\end{array}$ \\
\hline & & & $\frac{1}{1}$ & $\begin{array}{l}2 \\
1 \\
2 \\
1\end{array}$ & $\begin{array}{l}2 \\
3 \\
2 \\
2\end{array}$ & & 1 & & $\begin{array}{l}3 \\
1\end{array}$ & $\begin{array}{l}6 \\
9 \\
7 \\
3\end{array}$ \\
\hline & & & 1 & $I$ & 3 & & $\frac{1}{1}$ & & $\frac{1}{1}$ & $\begin{array}{l}5 \\
2 \\
2\end{array}$ \\
\hline & & 1. & & & $\frac{1}{1}$ & & & & & $\begin{array}{l}2 \\
2 \\
1\end{array}$ \\
\hline & & 2 & & & & & 1 & 3 & 2 & 8 \\
\hline Total & 2 & 9 & 16 & 11 & 24 & 6 & 8 & 6 & 11 & 93 \\
\hline
\end{tabular}

Median 51-55

Mean 54.6 


\section{TABLE 28}

NUMBER OF SCIENCE AREAS IN WHICH BIOLOGY TEACHERS RECEIVED CREDIT

\begin{tabular}{|c|c|c|c|c|c|c|c|c|c|c|c|}
\hline \multirow[t]{2}{*}{ Number of Areas } & \multicolumn{9}{|c|}{ School Size } & \multirow{2}{*}{$\begin{array}{l}\text { Per } \\
\text { Cent }\end{array}$} & \multirow[t]{2}{*}{ Total } \\
\hline & $\begin{array}{l}10- \\
24\end{array}$ & $\begin{array}{l}25- \\
49\end{array}$ & $\begin{array}{l}50- \\
74\end{array}$ & $\begin{array}{l}75- \\
99\end{array}$ & $\begin{array}{l}100- \\
199\end{array}$ & $\begin{array}{l}200- \\
299\end{array}$ & $\begin{array}{l}300- \\
499\end{array}$ & $\begin{array}{l}500- \\
999\end{array}$ & $\begin{array}{l}1000- \\
2400\end{array}$ & & \\
\hline None & & & & & & & & & 1 & 1.1 & 1 \\
\hline One & 1 & 1 & 2 & 2 & & 3 & & & & 9.7 & 9 \\
\hline Two & & 1 & 2 & 1 & 4 & 2 & 3 & 2 & 3 & 19.3 & 18 \\
\hline Three & & 6 & 7 & 8 & 14 & & 2 & 2 & 3 & $45 \cdot 2$ & 42 \\
\hline Four & 1 & 1 & 5 & & 6 & 1 & 3 & 2 & 4 & 24.7 & 23 \\
\hline Total & 2 & 9 & 16 & 11 & 24 & 6 & 8 & 6 & 11 & 100 . & 93 \\
\hline
\end{tabular}


high as in the other two states studied. A teaching major in any field is determined by listing those courses which are considered necessary for sufficient mastery of the field to do an acceptable job of teaching it. A teaching minor, which is usually from one-half to two-thirds as extensive as a major, sets up what is considered an absolute minimum of necessary undergraduate preparation. In this field of biology teaching, for example, Montana State University requires 47 or 48 quarter-credits for a teaching major, 31 or 32 quarter-credits for a teaching minor. It is surely significant, then, that of the 93 biology teachers whose transcripts were studied, 58 were teaching it with less credits than a minor requires, and only 16, or a little over 17 per cent, had enough credits for a teaching major in the subject. Fortunately, most of the betterprepared teachers are in the larger schools, where more students are, and they are teaching on an average more biology classes per day as part of their schedules.

\section{Chemistry Teachers}

Chemistry background of chemistry teachers. This study included 42 transcripts, or 38.2 per cent of the 110 Montana teachers teaching some chemistry classes, and of these, 90.5 per cent showed at least one course in chemistry. The median number of quarter-credits of preparation 
was 20 , with 19 of the 38 who had had some chemistry courses lying both above and below this point. (See Table 29.) The mean was 21.7 credit hours. There were 20 of the 42 who had taken only one year or less of college chemistry courses as preparation for teaching the subject; in other words, they had little or no experience in quantitative measurement and in organic chemistry.

Koelsche found that of the 175 chemistry teachers he studied, 96.5 per cent had had one or more chemistry courses; the median, calculated from those who had some chemistry training, was in the 26-30 interval. Pella, using data from 261 Wisconsin teachers, found that 96.2 per cent had had some chemistry. He found for the latter a mean of 27.7 credits.

Biology background of chemistry teachers. Table 30, relating to preparation of chemistry teachers in biology, shows that 97.6 per cent had had some biology--an interesting figure when compared with Table 29, for it shows that more of the chemistry teachers had had biology than had had chemistry itself. Seven showed sufficient biology credits for a teaching major in that field, and eleven others had enough credits for a biology teaching minor. In other words, about 43 per cent of Montana's chemistry teachers could be certified to teach biology. The median number of 
TABLE 29

CREDITS EARNED IN CHEIMISTRY BY CHEMISTRY TEACHERS

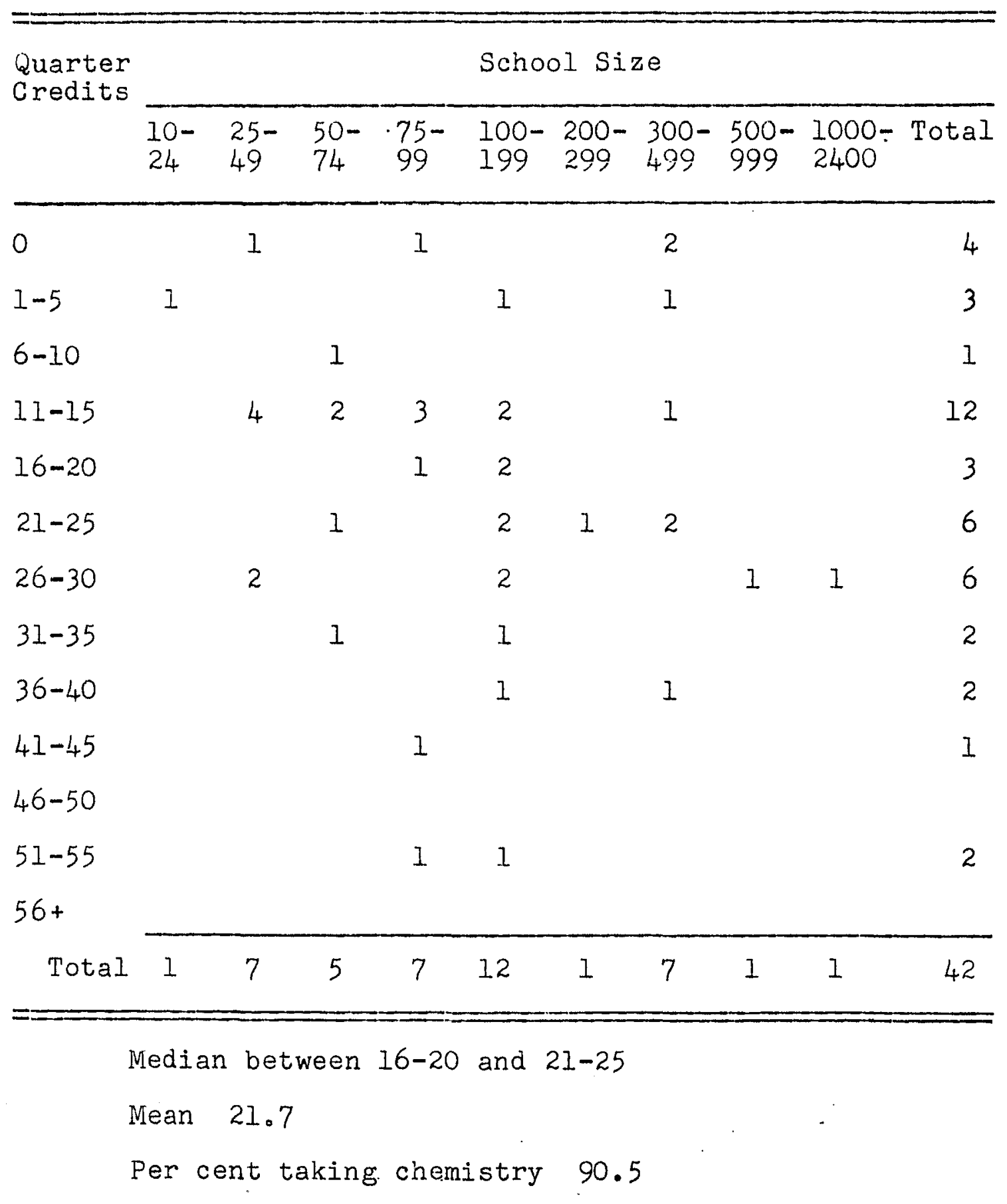


TABLE 30

CREDITS EARNED IN BIOLOGY BY CHEMISTRY TEACHERS

\begin{tabular}{|c|c|c|c|c|c|c|c|c|c|c|}
\hline \multirow{2}{*}{$\begin{array}{l}\text { Quarter } \\
\text { Credits }\end{array}$} & \multicolumn{10}{|c|}{ School Size } \\
\hline & $\begin{array}{l}10- \\
24\end{array}$ & $\begin{array}{l}25- \\
49\end{array}$ & $\begin{array}{l}50- \\
74\end{array}$ & $\begin{array}{l}75- \\
99\end{array}$ & $\begin{array}{l}100- \\
199\end{array}$ & $\begin{array}{l}200- \\
299\end{array}$ & $\begin{array}{l}300- \\
499\end{array}$ & $\begin{array}{l}500- \\
999\end{array}$ & $\begin{array}{l}1000- \\
2400\end{array}$ & Total \\
\hline 0 & & & & & & & & & 1 & 1 \\
\hline $1-5$ & 1 & 1 & 1 & & 3 & & 1 & & & 7 \\
\hline $6-10$ & & 2 & & 2 & & & & & & 4 \\
\hline $11-15$ & & 1 & 1 & 1 & 1 & & & & & 4 \\
\hline $16-20$ & & $I$ & & & & & 1 & & & 2 \\
\hline $21-25$ & & & 1 & & 5 & & & & & 6 \\
\hline $26-30$ & & & & & & & & & & \\
\hline $31-35$ & & 1 & 1 & 2 & 2 & 1 & & & & 7 \\
\hline $36^{\circ}-40$ & & & & & & & & & & \\
\hline $41-45$ & & & & 2 & 1 & & 1 & & & 4 \\
\hline $46-50$ & & & 1 & & & & & & & 1 \\
\hline $51-55$ & & & & & & & 2 & & & 2 \\
\hline $56+$ & & 1 & & & & & 2 & 1 & & 4 \\
\hline Total & 1 & 7 & 5 & 7 & 12 & 1 & 7 & 1 & 1 & 42 \\
\hline
\end{tabular}

Median 21-25

Mean 26.0

Per cent taking biology 97.6 
credits lay in the 21-25 interval, and the mean was 26 credits--both higher figures than those of the preceding table showing preparation in chemistry. One might conclude that chemistry is being taught by biology teachers.

Koelsche found that 72.5 per cent of those teaching chemistry in Ohio had had some biology; the median calculated lay in the 26-30 interval. He found that 43.5 per cent, or almost half, of the chemistry teachers he studied had enough credits for a minor in biology, and 17.7 per cent had enough for a teaching major in that area. Pella found that 213 , or 81.5 per cent, of the 261 Wisconsin chemistry teachers he studied had some biological science. There were 72.7 per cent who showed 15 credits or better (a year's work or more), and the mean was 23.8 credits.

Physics background of chemistry teachers. Table 31 , which gives the amount of academic preparation in physics of the chemistry teachers studied, shows that 88.1 per cent had had some physics courses. The median number of hours of preparation lies in the $11-15$ interval, with a mean calculated, for those who had had some physics, of 11.5 credit hours. Only five of the 42 teachers had had more than a year's work in physics; almost half had had less than an average college year's courses of 12 to 15 quarter-credits. Koelsche found that 77.7 per cent of the 175 
TABLE 31

CREDITS EARNED IN PHYSICS BY CHEMISTRY TEACHERS

\begin{tabular}{|c|c|c|c|c|c|c|c|c|c|c|}
\hline \multirow{2}{*}{$\begin{array}{l}\text { Quarter } \\
\text { Credits }\end{array}$} & \multicolumn{10}{|c|}{ School Size } \\
\hline & $\begin{array}{l}10- \\
24\end{array}$ & $\begin{array}{l}25- \\
49\end{array}$ & $\begin{array}{l}50- \\
74\end{array}$ & $\begin{array}{l}75- \\
99\end{array}$ & $\begin{array}{l}100- \\
199\end{array}$ & $\begin{array}{l}200- \\
299\end{array}$ & $\begin{array}{l}300- \\
499\end{array}$ & $\begin{array}{l}500- \\
999\end{array}$ & $\begin{array}{l}1000- \\
2400\end{array}$ & Total \\
\hline 0 & 1 & 1 & 1 & 1 & 1 & & & & & 5 \\
\hline $1-5$ & & & & & 1 & 1 & 1 & & & 3 \\
\hline $6-10$ & & 2 & 2 & 3 & 2 & & 2 & 1 & & 12 \\
\hline $11-25$ & & 3 & 2 & 2 & 6 & & 4 & & & 17 \\
\hline $16-20$ & & & & 1 & 2 & & & & & 3 \\
\hline $21-25$ & & 1 & & & & & & & 1 & 2 \\
\hline $26-30$ & & & & & & & & & & \\
\hline $31-35$ & & & & & & & & & & \\
\hline $36-40$ & & & & & & & & & & \\
\hline $41-45$ & & & & & & & & & & \\
\hline $46-50$ & & & & & & & & & & \\
\hline $51-55$ & & & & & & & & & & \\
\hline $56+$ & & & & & & & & & & \\
\hline Total & 1 & 7 & 5 & 7 & 12 & 1 & 7 & 1 & $I$ & 42 \\
\hline
\end{tabular}

Nedian 11-15

Mean 11.5

Per cent taking physics 88.1 
teachers he studied had taken one or more physics courses; the median lay in the 16-20 interval. Pella's study showed that 90.4 per cent of the Wisconsin chemistry teachers had had some physics. The mean number of credit hours calculated by Pella was 17.2.

Geology background of chemistry teachers. Threefourths of Montana's chemistry teachers studied have had no geology. Table 32, which deals with chemistry teachers' preparation in geology, shows that 30 of the 42 have had no geology courses. Only 28.6 per cent had had any geology; only three had had more than one quarter's work. The median number of hours was in the 1-5 interval, with a mean of 4.3 credits for those who had taken some geology. Koelsche found that 18.9 per cent of the Ohio chemistry teachers had had one or more geology courses; his. median was in the 6-10 interval. Pella found that 55.7 per cent of the Wisconsin chemistry teachers had taken some work in geology, with a mean of 8 credits.

All three studies show this science area to be the weakest in chemistry teachers' preparation, although a knowledge of geology would be a distinct asset to them. This is particularly true in Montana, where the extraction, processing, and refining of ores is so important a part of the economy of the state; and the petroleum industry also 
TABLE 32

CREDITS EARNED IN GEOLOGY BY CHEMISTRY TEACHERS

\begin{tabular}{|c|c|c|c|c|c|c|c|c|c|c|}
\hline \multirow{2}{*}{$\begin{array}{l}\text { Quarter } \\
\text { Credits }\end{array}$} & \multicolumn{10}{|c|}{ School Size } \\
\hline & $\begin{array}{l}10- \\
24\end{array}$ & $\begin{array}{l}25- \\
49\end{array}$ & $\begin{array}{l}50- \\
74\end{array}$ & $\begin{array}{l}75- \\
99\end{array}$ & $\begin{array}{l}100- \\
199\end{array}$ & $\begin{array}{l}200- \\
299\end{array}$ & $\begin{array}{l}300- \\
499\end{array}$ & $\begin{array}{l}500- \\
999\end{array}$ & $\begin{array}{l}1000- \\
2400\end{array}$ & Total \\
\hline 0 & 1 & 7 & 5 & 5 & 6 & 1 & 3 & 1 & 1 & 30 \\
\hline $1-5$ & & & & 2 & 4 & & 3 & & & 9 \\
\hline $6-10$ & & & & & 2 & & 1 & & & 3 \\
\hline \multicolumn{11}{|l|}{$11-15$} \\
\hline \multicolumn{11}{|l|}{$16-20$} \\
\hline \multicolumn{11}{|l|}{$21-25$} \\
\hline \multicolumn{11}{|l|}{$26-30$} \\
\hline \multicolumn{11}{|l|}{$31-35$} \\
\hline \multicolumn{11}{|l|}{$36-40$} \\
\hline \multicolumn{11}{|l|}{$41-45$} \\
\hline \multicolumn{11}{|l|}{$46-50$} \\
\hline \multicolumn{11}{|l|}{$51-55$} \\
\hline \multicolumn{11}{|l|}{$56+$} \\
\hline Total & 1 & 7 & 5 & 7 & 12 & 1 & 7 & 1 & 1 & 42 \\
\hline \multicolumn{11}{|c|}{ Median $1-5$} \\
\hline & Mean & $4 \cdot 3$ & & & & & & & & \\
\hline & Per ce & ent $t$ & ring & D & gy & 28.6 & & & & \\
\hline
\end{tabular}


is of increasing importance in Montana. The entire field of inorganic chemistry is closely related to geology, and a knowledge of geology could much enrich the teaching of chemistry. Functional knowledge in such related fields is a "rabbit in the hat" for the science teacher.

Total science background of chemistry teachers. 42 transcripts of chemistry teachers showed some training in science. (See Table 33.) The median number of credits earned lay in the 61-65 interval, with a mean of 60.3, a substantial number of credit hours. Table 33 also shows, when studied in conjunction with the four previous tables, that chemistry is taught in most cases not by individuals who were especially trained to teach it but by those who teach it because they have had at least some preparation in that subject.

It is difficult to say how many chemistry credits a good chemistry teacher needs to have had. There is no doubt that one year of college chemistry is inadequate, for chemistry is a subject that cannot be taught successfully with only a superficial or textbook knowledge: it is much too complex.

The chemistry teachers whose transcripts were examined are very satisfactory in breadth of training. There was only one teacher, representing 2.4 per cent of the 
TABLE 33

TOTAL SCIENCE CREDITS EARNED BY CHEMISTRY TEACHERS

\begin{tabular}{|c|c|c|c|c|c|c|c|c|c|c|}
\hline \multirow{2}{*}{$\begin{array}{l}\text { Quarter } \\
\text { Credits }\end{array}$} & \multicolumn{10}{|c|}{ School Size } \\
\hline & $\begin{array}{l}10- \\
24\end{array}$ & $\begin{array}{l}25- \\
49\end{array}$ & $\begin{array}{l}50- \\
74\end{array}$ & $\begin{array}{l}75- \\
99\end{array}$ & $\begin{array}{l}100- \\
199\end{array}$ & $\begin{array}{l}200- \\
299\end{array}$ & $\begin{array}{l}300- \\
499\end{array}$ & $\begin{array}{l}500- \\
999\end{array}$ & $\begin{array}{l}1000- \\
2400\end{array}$ & Total \\
\hline $\begin{array}{l}0 \\
1-5 \\
6-10 \\
11-15 \\
16-20 \\
21-25 \\
26-30 \\
31-35 \\
36-40 \\
41-45 \\
46-50 \\
51-55 \\
56-60 \\
61-65 \\
66-70 \\
71-75 \\
76-80 \\
81-85 \\
86-90 \\
91-95 \\
96-100 \\
\text { over } 100\end{array}$ & ) & $\begin{array}{l}2 \\
1 \\
1 \\
1 \\
\end{array}$ & $\begin{array}{l}I \\
I \\
I\end{array}$ & $\begin{array}{l}1 \\
2 \\
2\end{array}$ & $\begin{array}{l}1 \\
2 \\
1 \\
2 \\
2 \\
1 \\
1\end{array}$ & $\begin{array}{c}- \\
1\end{array}$ & $\begin{array}{l}2 \\
1 \\
1 \\
1 \\
1\end{array}$ & 1 & 1 & $\begin{array}{l}2 \\
1 \\
\\
1 \\
4 \\
3 \\
1 \\
2 \\
2 \\
3 \\
7 \\
3 \\
2 \\
2 \\
1 \\
1 \\
2 \\
2 \\
3\end{array}$ \\
\hline Total & 1 & 7 & 5 & 7 & 12 & 1 & 7 & 1 & 1 & 42 \\
\hline
\end{tabular}

Median 61-65

Mean 60.3 
total studied, with preparation in only one area; 11.9 per cent had preparation in two areas, 52.4 per cent in three areas, and 33.3 per cent in all four. (See Table 340) In other words, more than four-fifths of the 42 had training in at least three major science fields. One can conclude from the evidence submitted that these chemistry teachers are broadly educated in science but that they need more training in chemistry itself and also in physics and geology in order to reach an optimum level of preparation.

\section{Physics Teachers}

Physics background of physics teachers. The physics background of Montana's physics teachers who were analyzed averaged only two courses. The tables relating to physics teachers present data accumulated from 43 transcripts, representing 44.3 per cent of those teaching physics in Montana at the time this study was made. There were 95.3 per cent of the transcripts which showed some preparation in the area of physics itself, with the median in the 6-10 interval, and with a mean, calculated from those having had some physics, of 10.1 credits.

Koelsche found that 91.7 per cent of the 84 physics teachers whose transcripts he analyzed had had some work in physics; the median was in the 16-20 interval. Pella found that 93 per cent of 258 Wisconsin physics teachers had had 
TABLE 34

NUNBER OF SCIENCE AREAS IN WHICH CHEMISTRY

TEACHERS RECEIVED CREDIT

\begin{tabular}{|c|c|c|c|c|c|c|c|c|c|c|c|}
\hline \multirow[t]{2}{*}{ Number of Areas } & \multicolumn{9}{|c|}{ School Size } & \multirow{2}{*}{$\begin{array}{l}\text { Per } \\
\text { Cent }\end{array}$} & \multirow[t]{2}{*}{ Total } \\
\hline & $\begin{array}{l}10- \\
24\end{array}$ & $\begin{array}{l}25- \\
49\end{array}$ & $\begin{array}{l}50- \\
74\end{array}$ & $\begin{array}{l}75- \\
99\end{array}$ & $\begin{array}{l}100- \\
199\end{array}$ & $\begin{array}{l}200- \\
299\end{array}$ & $\begin{array}{l}300- \\
499\end{array}$ & $\begin{array}{l}500- \\
999\end{array}$ & $\begin{array}{l}1000- \\
2400\end{array}$ & & \\
\hline \multicolumn{12}{|l|}{ None } \\
\hline One & & 1 & & & & & & & & 2.4 & 1 \\
\hline Two & $I$ & & 1 & 1 & & & 1 & & 1 & 11.9 & 5 \\
\hline Three & & 4 & 3 & 5 & 6 & 1 & 3 & & & 52.4 & 22 \\
\hline Four & & 2 & 1 & 1 & 6 & & 3 & 1 & & $33 \cdot 3$ & 14 \\
\hline Total & 1 & 7 & 5 & 7 & 12 & 1 & 7 & 1 & 1 & 100 & 42 \\
\hline
\end{tabular}


some preparation; he found a mean of 20.2 credit hours for the 240 teachers who had had a course or more of preparation.

Only three of the Montana teachers studied had had more than the introductory college physics courses, and approximately one-half showed less than one year's preparation. (See Table 35.) Two teachers had no preparation in the area at all; one had not even had a high school course in physics.

Physics is admittedly a difficult course to grasp and to teach. To try to teach it with a weak background does a disservice to the pupils, and fails to meet the nation's current needs. There has been a substantial amount of research in curriculum construction in the area of physics by competent individuals working under a National Science Foundation grant. 40 The trial curriculum which has emerged is more difficult to present than those ordinarily found in physics texts in use in secondary schools; it therefore requires more background on the part of the teacher. The course of study outlined for physics which has been prepared recently for use in Montana is also more

40 Physics, Preliminary Edition, Physical Science Study Committee, Massachusetts Institute of Technology, Cambridge, Mass., 1958. 
TABLE 35

CREDITS EARNED IN PHYSICS BY PHYSICS TEACHERS

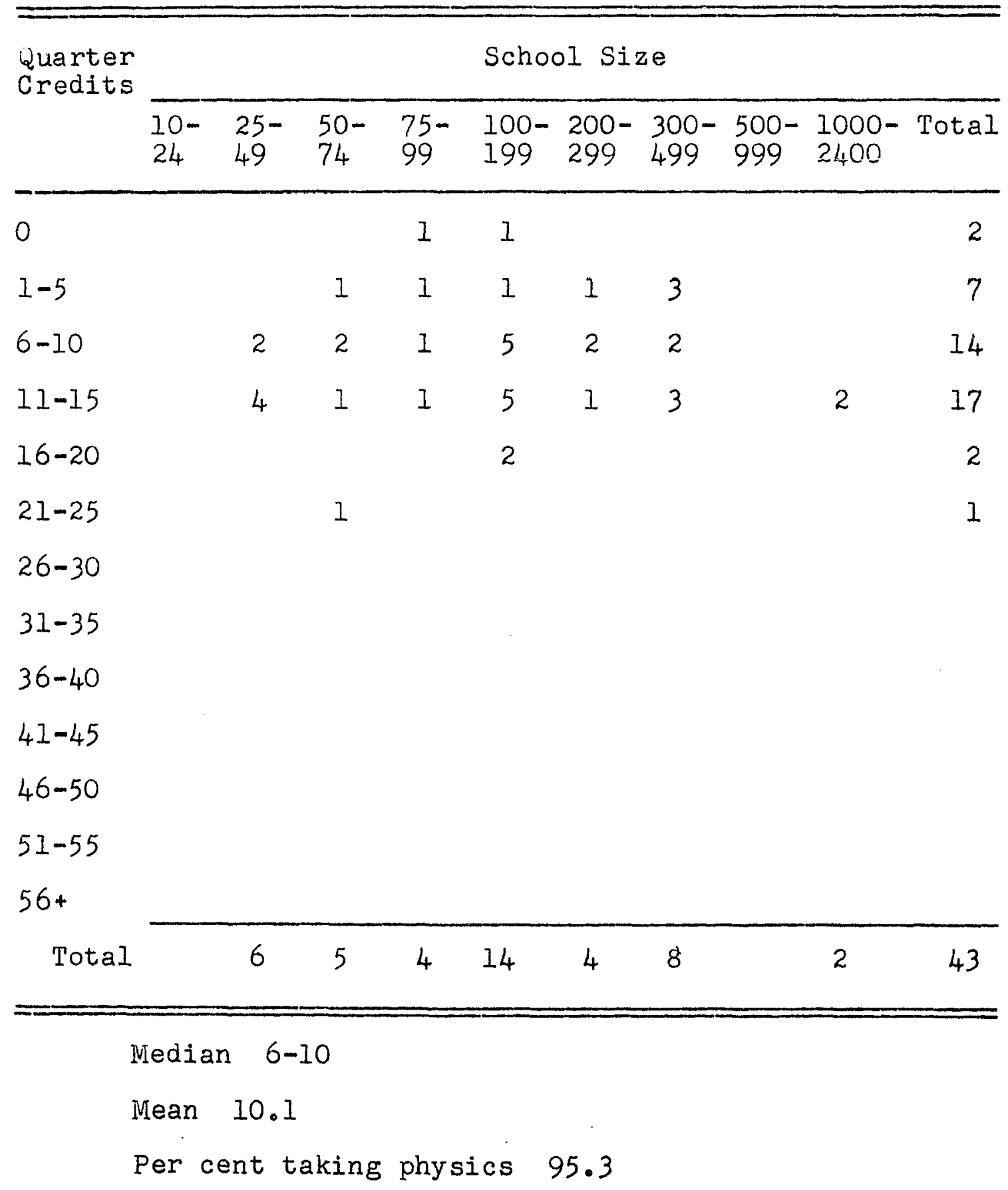


difficult to present. 41 It seems doubtful that traditional physics courses can long remain in the curricula of many of our small high schools unless considerably more emphasis is put on the training of high school physics teachers. But doing so also presents problems, for unless the demand for physics teachers changes radically, we would soon find ourselves with an oversupply of teachers trained specifically for areas in which there was little demand for the product. Table 12 gave an indication of the demand: there were only four full-time physics teachers in all Montana. A possible solution to the dilemma will be developed in Chapter V.

Biology background of physics teachers. Practically all physics teachers in Montana have had some college courses in biology. Table 36, which records the number of hours of biology credits earned by physics teachers, discloses that 97.7 per cent have had some biology. The median, which lies in the 2l-25 interval, and the mean, 27 credit hours, indicate that a substantial amount of the physics taught in Montana high schools is taught by teachers trained in biology. This background would be excellent, except they lack preparation in physics itself. (See Table 35 again.)

\footnotetext{
${ }^{41}$ Curriculum Science Course of Study for Montana, Tentative Physics Outline, Department of Public Instruction, Helena, Mont。, 1959.
} 
TABLE 36

CREDITS EARNED IN BIOLOGY BY PHYSICS TEACHERS

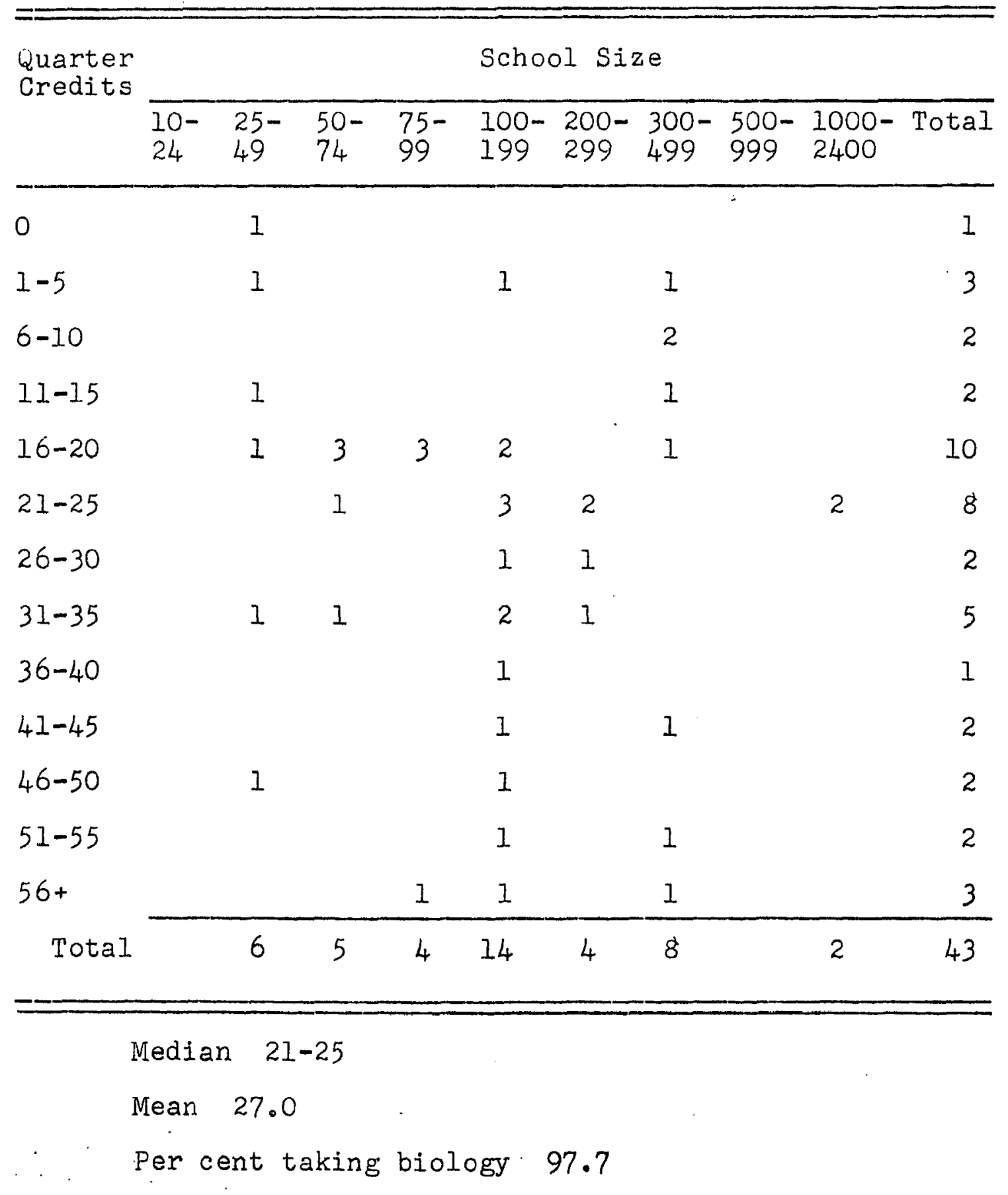


Koelsche found that 62 per cent of the physics teachers had had some biology; the median, in the 26-30 interval, was higher than that for preparation in physics. Pella found that 75.4 per cent of Wisconsin physics teachers had had some preparation in biology. He found a mean of 19 credits for those who had had some biology training.

Chemistry background of physics teachers. Only onefifth of Montana physics teachers have less than a year's work in chemistry. Table 37 shows the preparation in chemistry of the 43 physics teachers studied. All but one, or 97.7 per cent, had had one or more chemistry courses; 18 had more than a year's credits, and eight had less. The median number of hours lay in the 11-15 interval, while the mean, calculated for the 42 who had had some chemistry, was 18.4 credits. If we were dealing with bona fide physics teachers, this preparation in chemistry would be satisfactory, but what we are dealing with are teachers trained for other fields, primarily biology and chemistry. This table therefore must also be examined and interpreted along with Table 35, which showed preparation in physics。

In Ohio Koelsche found that 91.7 per cent of the 84 physics teachers he studied had had some chemistry, and he found exactly. the same percentage of the same group had had some physics. He also found the chemistry median to be. 
TABLE 37

CREDITS EARNED IN CHEMISTRY BY PHYSICS TEACHERS

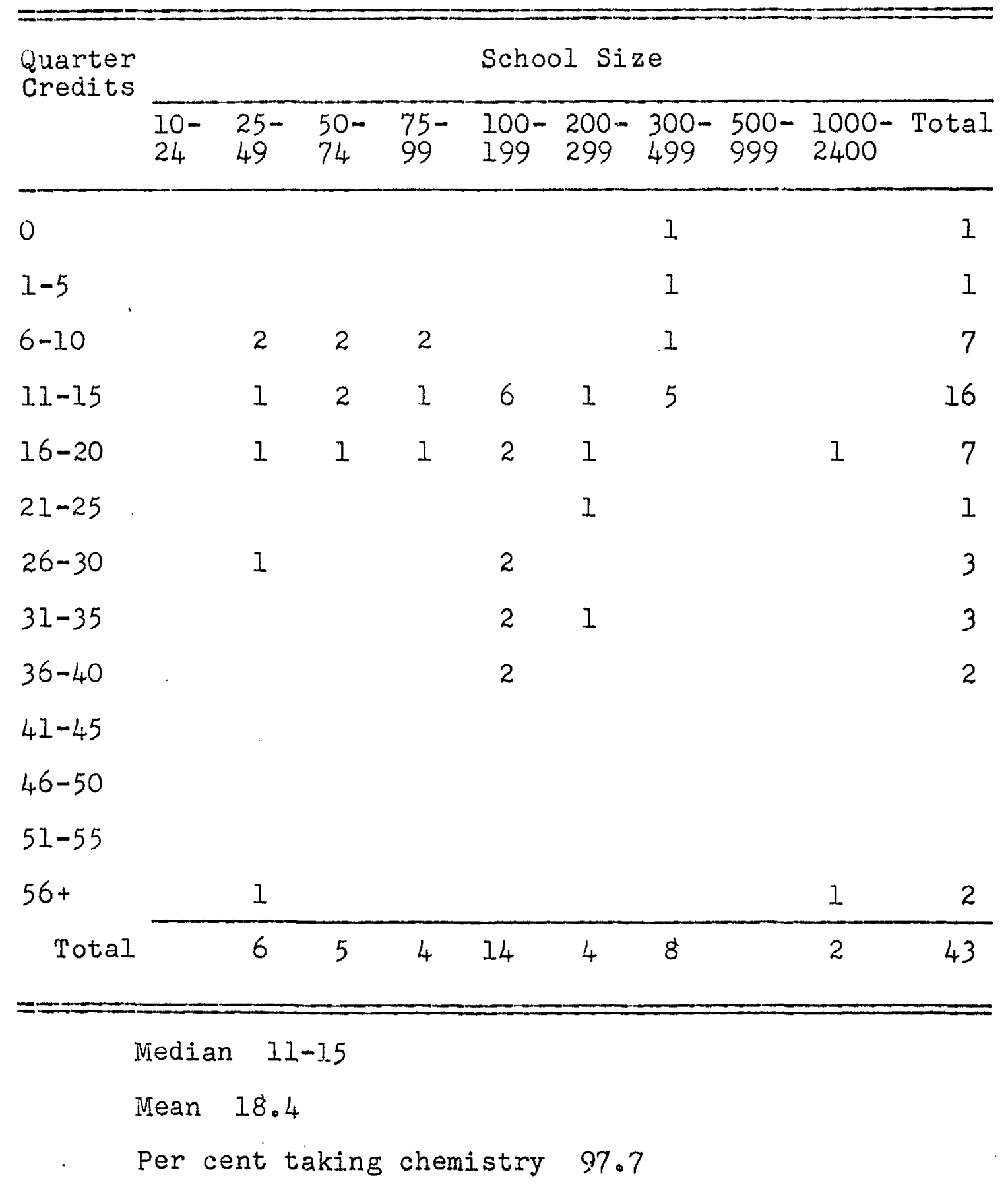


higher than that for preparation in physics--26-30 for the former, 16-20 for the latter. Koelsche's data show that Ohio physics teachers also have greater preparation in other fields than physics. Pella's study showed that 93.4 per cent of the physics teachers studied had had some chemistry. Here again the physics teacher shows slightly better preparation in chemistry (with a mean of 23.8 credits) than in physics (with a mean of only 20.2 credits). Probably Ohio and Wisconsin physics teachers, like Montana physics teachers, are teaching the subject more because they are assigned to do so than because they prepared to teach it.

Geology background of physics teachers. Three-fifths of Montana's physics teachers examined have had no geology. Table 38 indicates that 60.5 per cent of the physics teachers have had no geology; only four of the transcripts showed more than a quarter's work in the subject, and none showed as much as a year's work. The median lay in the 1-5 inter$\mathrm{val}$, and the mean calculated was 4.2 credits.

Koelsche found that only 15.5 per cent of the Ohio physics teachers studied had had any geology; the median of hours credit lay in the 6-10 interval. Pella found that 60 per cent of his Wisconsin transcripts showed some geology; the mean was 8.5 credits。

It is difficult to present a case for the inclusion 
TABLE 38

CREDITS EARNED IN GEOLOGY BY PHYSICS TEACHERS

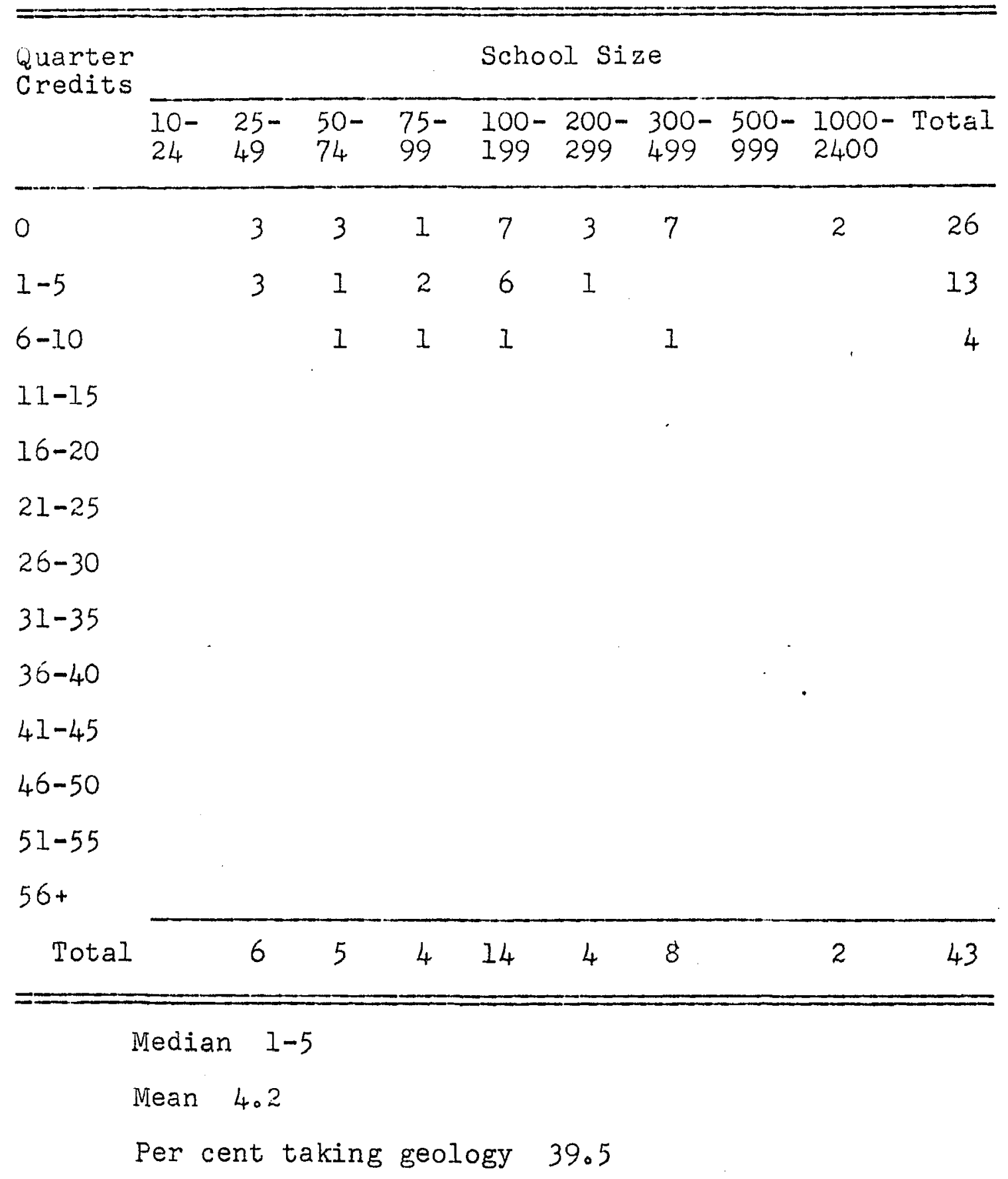


of geology in the training of those who are going to teach nothing but physics, except that high school science teachers should be scientifically educated individuals capable of orienting high school pupils to the broad field of science. At the high school level the teacher needs enough background in all the sciences to be able to interpret specific fields to pupils whose interest and aptitude lie in specific areas. His real duty is to produce scientifically literate citizens, to recognize scientific talent in his pupils, to give such pupils fundamental scientific information, and to work with those talented ones so that they will continue on to professional training in selected areas。

Finally, the physics teacher should have background knowledge concerning fossil fuels, hydroelectric power, and 3uch other energy sources as the radioactive minerals, and this background implies some experiences in the field of geology。

Total science background of physics teachers. Tables 39 and 40, which summarize the amount and breadth of the physics teacher's science training, show that he has a substantial number of science credits. He has accumulated enough to shove the median up into the 56-60 interval; only two whose transcripts were examined had less than 30 hours 
TABLE 39

TOTAL SCIENCE CREDITS EARNED BY PHYSICS TEACHERS

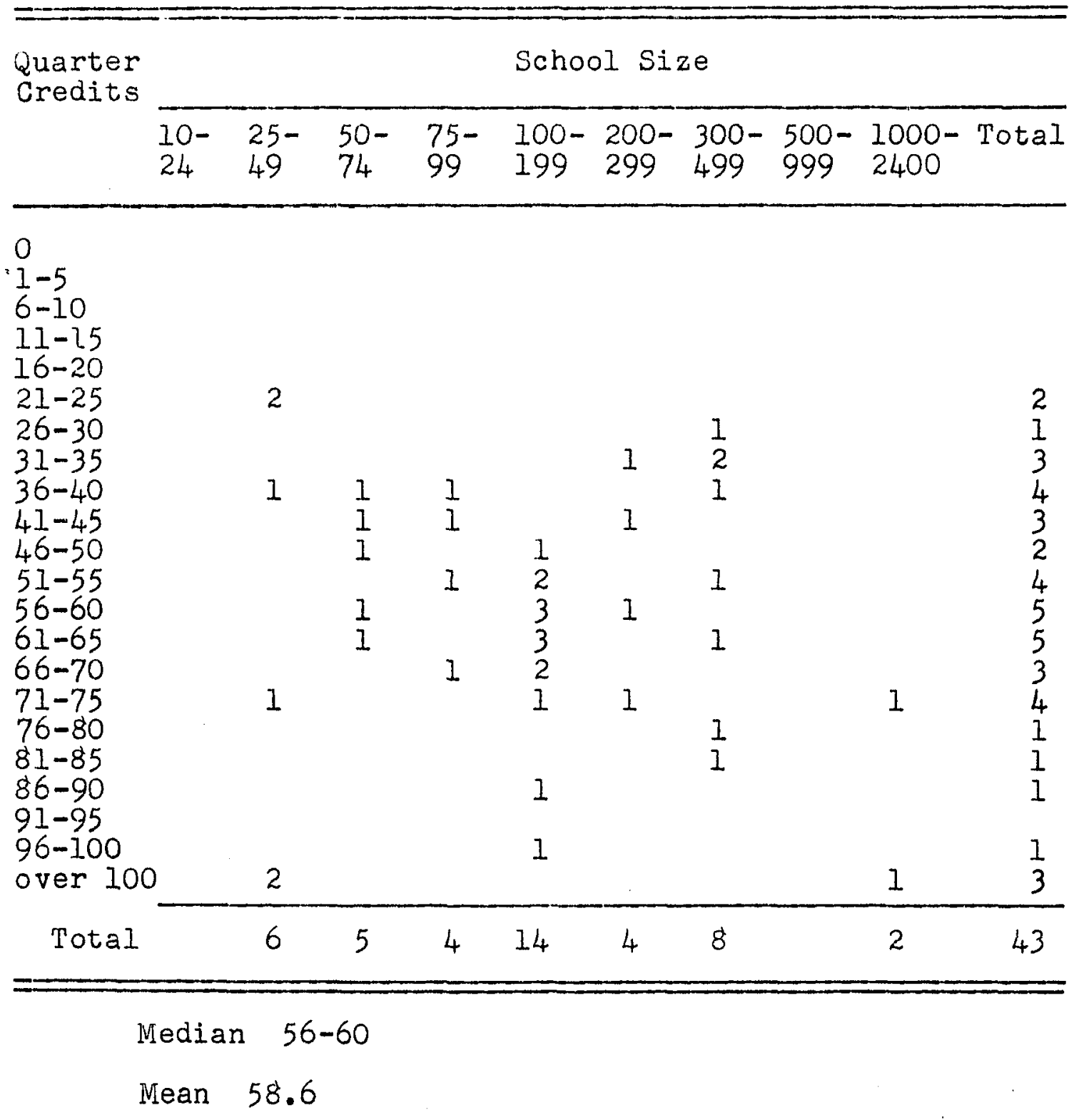


of credit. The data in Table 40 point to broad training; only two teachers show training in two fields, 58.1 per cent show courses in three areas, and 37.2 per cent in all four areas tabulated.

However, two weaknesses in the training pattern of these teachers are apparent. The most glaring one is poor preparation in physics, but lack of preparation in geology is also obvious. These two weaknesses have both been pointed out previously.

\section{Astronomy in Background of Science Teachers}

Nothing has been said so far concerning astronomy. It is sometimes included in the college physics program, or it may rarely be part of the mathematics program. That it has not been duly recognized as a foundation subject in science is evident from its absence from the background training of our science teachers. The increasing amount of emphasis on astronomical achievements and the impact which these achievements are having on our society indicate that it should be included. Survey courses in such areas need to be included in the background of our science teachers: they need not be--in fact, they should not be--highly technical courses involving the manipulation of complicated mathematical formulas. Astronomy was once taught as a subject in our high schools. I do not advocate that we return 


\section{TABLE 40}

NUMBER OF SCIEINCE AREAS IN WHICH PHYSICS TEACHERS RECEIVED CREDIT

\begin{tabular}{|c|c|c|c|c|c|c|c|c|c|c|c|}
\hline \multirow[t]{2}{*}{ Number of Areas } & \multicolumn{9}{|c|}{ School Size } & \multirow{2}{*}{$\begin{array}{l}\text { Per } \\
\text { Cent }\end{array}$} & \multirow[t]{2}{*}{ Total } \\
\hline & $\begin{array}{l}10- \\
24\end{array}$ & $\begin{array}{l}25- \\
49\end{array}$ & $\begin{array}{l}50- \\
74\end{array}$ & $\begin{array}{l}75- \\
99\end{array}$ & $\begin{array}{l}100- \\
199\end{array}$ & $\begin{array}{l}200-- \\
299\end{array}$ & $\begin{array}{l}300- \\
499\end{array}$ & $\begin{array}{l}500- \\
999\end{array}$ & $\begin{array}{l}1000- \\
2400\end{array}$ & & \\
\hline \multicolumn{12}{|l|}{ None } \\
\hline \multicolumn{12}{|l|}{ One } \\
\hline T.wo & & & & & 1 & & 1 & & & 4.7 & 2 \\
\hline Three & & 4 & 3 & 2 & 6 & 3 & 6 & & 1 & 58.1 & 25 \\
\hline Four & & 2 & 2 & 2 & 7 & $I$ & 1 & & 1 & 37.2 & 16 \\
\hline Total & & 6 & 5 & 4 & 14 & 4 & 8 & & 2 & 100 & 43 \\
\hline
\end{tabular}


to teaching it there, but we should include enough instruction in astronomy so that our young people have up-todate, reliable information on space and its exporation, and on fundamental concepts of the universe itself and its important parts, so that they can learn to better distinguish science facts from science fiction and be able to appreciate the importance of basic research in this field.

\section{Other Pertinent Research}

In addition to the studies on science teacher preparation that have been cited, there have been some others that should be examined. Theodore Nelson, in his doctoral dissertation, studied 119 beginning teachers of science in Illinois. He found 78 of them teaching in small schools less than 250 pupils, assigned to teach all or most of the science courses offered. Only three were teaching a single science subject, while 92 taught courses outside the science field. Their preparation for teaching an all-inclusive science curriculum was inadequate: he found that seven had had no biology, 22 had had no chemistry, 29 no physics, and 91 no geology. Although it is not possible to make direct comparisons with his study, it does point to the same general pattern of training found in Montana: beginning with biology, where the strongest preparation is indicated, a decline follows from chemistry to physics to geology. 
Of those who taught general science, Nelson found that more than 25 per cent had not majored in any science field, and he also reported that more than 50 per cent had had no preparation in geology, astronomy, and meteorology. His conclusion was that at least half the students in the state of Illinois who were in classes where there were beginning science teachers were receiving substandard instruction from inadequately prepared teachers. 42

De Loach and Hall, studying chemistry teachers in Alabama, found that 23 per cent of the 167 teachers studied had had only general chemistry; 3 per cent had gone farther and had taken qualitative analysis; 11 per cent had had general chemistry and organic chemistry; 7 per cent had taken general chemistry plus qualitative and quantitative analysis and organic chemistry; and only 2 per cent had, in addition, taken physical chemistry. 43

A committee of the American Chemical Society, studying high school teaching of science, found that:

Of 5,84l teachers from the North Central Association schools 50 per cent of the men and 61 per cent of the women physics teachers had had less than 11 semester hours work in physics, while 12 per cent of the men and 19 per cent of the women chemistry teachers had had less than Il semester

\footnotetext{
$42_{\text {Will }}$ Burnett, Teaching Science in the Secondary School, 1957, p. 346. 43 Ibid., p. 347 .
} 
hours of chemistry. 44

Comparing the Science Teachers of Montana, Ohio, and Wisconsin

Information for this chapter was obtained by processing the transcripts of 205 Montana secondary science teachers who took preparatory training in one of the five units of the University of Wontana. The transcripts were examined to determine preparation in biology, chemistry, physics, and geology; the total number of science credits and breadth of training were also tabulated; and the resulting data were compared with similar information obtained in two other studies, one in Ohio and one in Wisconsin.

The statistics in this chapter present a population study rather than a sampling, and they give a fair picture of Montana science teachers, for they represent 205 of the 431 so employed, or 47.6 per cent of the total. In the separate categories the percentages are comparable: 50.2 per cent of the general science teachers of the state, 49.7 per cent of the biology teachers, 38.2 per cent of the chemistry teachers, and 44.3 per cent of the physics teachers. 
A detailed examination of the transcripts would show that all parts of the state and all school size categories are represented by these 205 teachers, and that they include a spread of from less than a year to more than 40 years of teaching experience.

The academic preparation of general science teachers in Montana compares favorably with that of teachers studied elsewhere, and actually shows somewhat greater breadth of preparation. All three studies which have been compared show lack of depth, with Montana lagging behind the other two states in this respect. Table 41 summarizes the findings of all three studies regarding the preparation of general science teachers.

Most of the biology teachers studied are teaching with insufficient preparation in their field; the median and mean for amount of preparation in biology were both below the amount necessary for even a teaching minor. The great disparity in credits between the poorly-prepared and the well-prepared biology teacher, and the fact that many are teaching biology who should not be, partly account for the low median and mean; but throughout this study those with no hours of credit have not been included when the mean was calculated. How biology teachers compare in preparation in Montana, Ohio, and Wisconsin is shown in Table 42. Montana's biology teachers appear somewhat better pre- 
TABLE 41

COMPARISON OF THE PREPARATION OF GENERAL SCIENCE TEACHERS IN MONTANA, OHIO, AND WISCONSIN

\begin{tabular}{|c|c|c|c|}
\hline Science Area & Montana & Ohio & Wisconsin \\
\hline $\begin{array}{l}\text { Biology } \\
\text { Per cent having had }\end{array}$ & 90.5 & 80.0 & 86.2 \\
\hline Median interval & $21-25$ & $26-30$ & -- \\
\hline Mean no. of credits & 23.6 & $-\cdots$ & 22.6 \\
\hline $\begin{array}{l}\text { Chemistry } \\
\text { Per cent having had }\end{array}$ & 74.2 & 71.6 & 87.7 \\
\hline Median interval & $11-15$ & $21-25$ & -- \\
\hline Mean no. of credits & 15.8 & -- & 21.5 \\
\hline $\begin{array}{l}\text { Physics } \\
\text { Per cent having had }\end{array}$ & 63.8 & 61.0 & 76.2 \\
\hline Median interval & $6-1.0$ & $11-15$ & -- \\
\hline Mean no. of credits & 10.0 & --- & 17.3 \\
\hline $\begin{array}{l}\text { Geology } \\
\quad \text { Per cent having had }\end{array}$ & 43.8 & 43.0 & 55.8 \\
\hline Median interval & $1-5$ & $6-10$ & -- \\
\hline Mean no. of credits & 4.8 & -- & 9.0 \\
\hline $\begin{array}{l}\text { Total Science Credits } \\
\text { Median }\end{array}$ & $41-45$ & $51-55$ & $56-60$ \\
\hline Mean & 45.2 & -- & 57.7 \\
\hline
\end{tabular}


TABLE 42

COMPARISON OF THE PREPARATION OF BIOLOGY TEACHERS

IN MONTANA, OHIO, AND WISCONSIN

\begin{tabular}{|c|c|c|c|}
\hline Science Area & Montana & Ohio & Wisconsin \\
\hline $\begin{array}{l}\text { Biology } \\
\text { Per cent having had }\end{array}$ & 98.9 & 97.1 & 97.8 \\
\hline Median interval & $21-25$ & $36-40$ & -- \\
\hline Mean no. of credits & 29.2 & -- & 30.7 \\
\hline $\begin{array}{l}\text { Chemistry } \\
\text { Per cent having had }\end{array}$ & 87.1 & 51.0 & 79.8 \\
\hline Median interval & $11-15$ & $16-20$ & -- \\
\hline Mean no. of credits & 15.6 & $-\cdots$ & 20.0 \\
\hline $\begin{array}{l}\text { Physics } \\
\text { Per cent having had }\end{array}$ & 67.7 & 32.0 & 59.4 \\
\hline Median interval & $6-10$ & $11-15$ & -- \\
\hline Mean no. of credits & 9.7 & -- & 14.9 \\
\hline $\begin{array}{l}\text { Geology } \\
\text { Per cent having had }\end{array}$ & 30.1 & 16.7 & 60.8 \\
\hline Median interval & $1-5$ & $6-10$ & -- \\
\hline Mean no. of credits & 4.6 & -- & 10.0 \\
\hline $\begin{array}{l}\text { Total Science Credits } \\
\text { Median }\end{array}$ & $51-55$ & $46-50$ & $61-65$ \\
\hline Mean & 54.6 & 49.5 & 62.7 \\
\hline
\end{tabular}


pared in chemistry and physics--fewer were without any background in these subjects. Ohio teachers showed more depth in biology itself.

Miontana chemistry teachers suffer slightly by comparison, especially in depth. (See Table 43.) Except in the field of biology they have less preparation than the teachers studied elsewhere. The better-than-average preparation of the Montana chemistry teacher in the field of biology probably indicates that he is not a high school chemistry teacher with a good biology background, but a high school biology teacher also teaching chemistry. There seems to be no significant disparity between the studies in other respects.

Montana's physics teachers are the most poorly prepared of the three groups. Table 44, which compares the preparation of physics teachers in the three states, shows Montana in a slightly more unfavorable light here than in the three other teaching fields. Again the Montana teacher shows lack of depth, and particularly in the area of physics itself, where a median interval of 6-10 is compared with 16-20 in Ohio, and a mean of 10.1 credits with a mean of 20.2 credits in wisconsin. It is even more noticeable that the Montana physics teacher is well prepared in biology in comparison to the Ohio or Wisconsin teacher--another indication that he is trying to be or is forced to be a jack- . 
TABLE 43

COMPARISON OF THE PREPARATION OF CHEMISTRY TEACHERS IN MONTANA, OHIO, AND WISCONSIN

\begin{tabular}{|c|c|c|c|}
\hline Science Area & Niontana & Ohio & Wisconsin \\
\hline $\begin{array}{l}\text { Chemistry } \\
\text { - Per cent having had }\end{array}$ & 90.5 & 96.5 & 96.2 \\
\hline Median interval & $-20-*$ & $26-30$ & -- \\
\hline Mean no. of credits & 21.7 & --- & 27.7 \\
\hline $\begin{array}{l}\text { Biology } \\
\text { Per cent having had }\end{array}$ & 97.6 & 72.5 & 81.5 \\
\hline Median interval & $21-25$ & $26-30$ & -- \\
\hline Mean no. of credits & 26.0 & --- & 23.8 \\
\hline $\begin{array}{l}\text { Physics } \\
\text { Per cent having had }\end{array}$ & 88.1 & 77.7 & 90.4 \\
\hline Median interval & $11-15$ & $16-20$ & -- \\
\hline Mean no. of credits & 11.5 & -- & 17.2 \\
\hline $\begin{array}{l}\text { Geology } \\
\text { Per cent having had }\end{array}$ & 28.6 & 18.9 & 55.7 \\
\hline Median interval & $1-5$ & $6-10$ & -- \\
\hline Mean no. of credits & $4 \cdot 3$ & -- & 8.0 \\
\hline $\begin{array}{l}\text { Total Science Credits } \\
\text { Median }\end{array}$ & $61-65$ & $70-75$ & $66-70$ \\
\hline Mean & 60.3 & -- & 64.9 \\
\hline
\end{tabular}

* Midway between two intervals. 
TABLE 44

COMPARISON OF THE PREPARATION OF PHYSICS TEACHERS

IN MONTANA, OHIO, AND WISCONSIN

\begin{tabular}{|c|c|c|c|}
\hline Science Area & Montana & Ohio & Wisconsin \\
\hline $\begin{array}{l}\text { Physics } \\
\text { Per cent having had }\end{array}$ & 95.3 & 91.7 & 93.0 \\
\hline ivedian interval & $6-10$ & $16-20$ & $-\cdots$ \\
\hline Wean no. of credits & 10.1 & -- & 20.2 \\
\hline $\begin{array}{l}\text { Biology } \\
\text { Per cent having had }\end{array}$ & 97.7 & 62.0 & 75.4 \\
\hline ivedian interval & $21-25$ & $26-30$ & $-\cdots$ \\
\hline Mean no. of credits & 27.0 & -- & 19.0 \\
\hline $\begin{array}{l}\text { Chemistry } \\
\text { Per cent having had }\end{array}$ & 97.7 & 91.7 & 93.4 \\
\hline Median interval & $11-15$ & $26-30$ & -- \\
\hline Mean no. of credits & 18.4 & -- & 23.8 \\
\hline $\begin{array}{l}\text { Geology } \\
\text { Per cent having had }\end{array}$ & 39.5 & 15.5 & 60.0 \\
\hline Median interval & $1-5$ & $6-10$ & -- \\
\hline Niean no. of credits & 4.2 & -- & 8.5 \\
\hline $\begin{array}{l}\text { Total Science Credits } \\
\text { Median }\end{array}$ & $56-60$ & $70-75$ & $61-65$ \\
\hline Mean & 58.6 & - & 70.3 \\
\hline
\end{tabular}


of-all-trades as a high school science teacher.

Teacher Turnover

The science teacher in a school with an enrollment of less than 200 has a poor statistical chance of remaining there for very long. Table 45 shows that, of the teachers studied, only one in the 10-24 school size group had been there for more than three years. However, these are not always beginning teachers, and do not necessarily move on to larger systems; seven of the 13 teachers in this smallest school size category had actually taught five years or more, moving from other small schools or from larger systems. Only about 30 per cent of those teaching in schools with an enrollment of less than 200 have tenure; the average science teacher's chance of obtaining tenure in a small high school in Montana is therefore not good. A comparison of the figures for average years of teaching experience with average years in the present school system shows that the difference is greatest in the smallest schools. This would indicate that the science teacher in the smaller school hardly has time to plan a science program for the school, let alone carry it out if he designs it. And since administrators also change frequently. in these smaller schools, long-range science programs are not probable。 Constant teacher turnover is one factor causing in- 
TABLE 45

TOTAL YEARS TAUGHT AND NUUBER OF YEARS

IN PRESENT SCHOOL SYSTEM

\begin{tabular}{|c|c|c|c|c|c|c|c|c|c|}
\hline & \multicolumn{9}{|c|}{ School Size } \\
\hline & $\begin{array}{l}10- \\
24\end{array}$ & $\begin{array}{l}25- \\
49\end{array}$ & $\begin{array}{l}50- \\
74\end{array}$ & $\begin{array}{l}75- \\
99\end{array}$ & $\begin{array}{l}100- \\
199\end{array}$ & $\begin{array}{l}200- \\
299\end{array}$ & $\begin{array}{l}300- \\
499\end{array}$ & $\begin{array}{l}500- \\
999\end{array}$ & $\begin{array}{l}1000- \\
2400\end{array}$ \\
\hline Number of Teachers & 13 & 46 & 39 & 45 & 83 & 19 & 36 & 72 & 63 \\
\hline $\begin{array}{l}\text { Years Experience } \\
\text { Tota1 }\end{array}$ & 99 & 327 & 211 & 311 & 737 & 192 & 459 & 912 & 660 \\
\hline Average & 7.5 & 7.1 & 5.4 & 6.9 & 8.8 & 10.0 & 12.5 & 12.6 & 10.5 \\
\hline $\begin{array}{l}\text { Years in Present School } \\
\text { Total }\end{array}$ & 22 & 148 & 61 & 139 & 402 & 116.5 & 281 & 397 & 398 \\
\hline Average & 1.7 & 3.2 & 1.6 & 3.0 & 4.8 & 6.1 & 7.9 & 5.5 & 6.3 \\
\hline
\end{tabular}


security, and the insecure teacher cannot be expected to achieve his teaching potential. Low salaries in smaller schools are another factor promoting teacher turnover, and since most small schools cannot compete with the salaries offered by larger schools, it is improbable that good teachers with experience will gravitate toward the small. high schools. There are, of course, "captive teachers" and those who for other reasons are in small systems, but, in general, small schools do not attract the better teachers.

Science Teachers' Salaries

Omitting the 39 administrators who taught science part-time, two part-time teachers, and 24 teachers whose salaries were not reported, the average salary of the 366 remaining science teachers was $\$ 4924$. The actual number of teachers in various salary intervals is shown in Figure III; the median lies in the $\$ 4500-\$ 4900$ interval. Over half of the salaries fall between $\$ 4000$ and $\$ 5000$.

Salary distribution according to school size is listed in Table 46. The minimum salary in each category is close enough to be of little significance, since there is a difference of only $\$ 250$ between the highest and lowest minimum. The maximum salaries are decidedly lower in the small schools; they range from a $\$ 5250$ maximum in the 10-24. category to $\$ 7400$ in the largest school group. 
FIGURE III

SALARIES OF FULL-TIME SECONDARY SCIENCE TEACHERS IN MONTANA

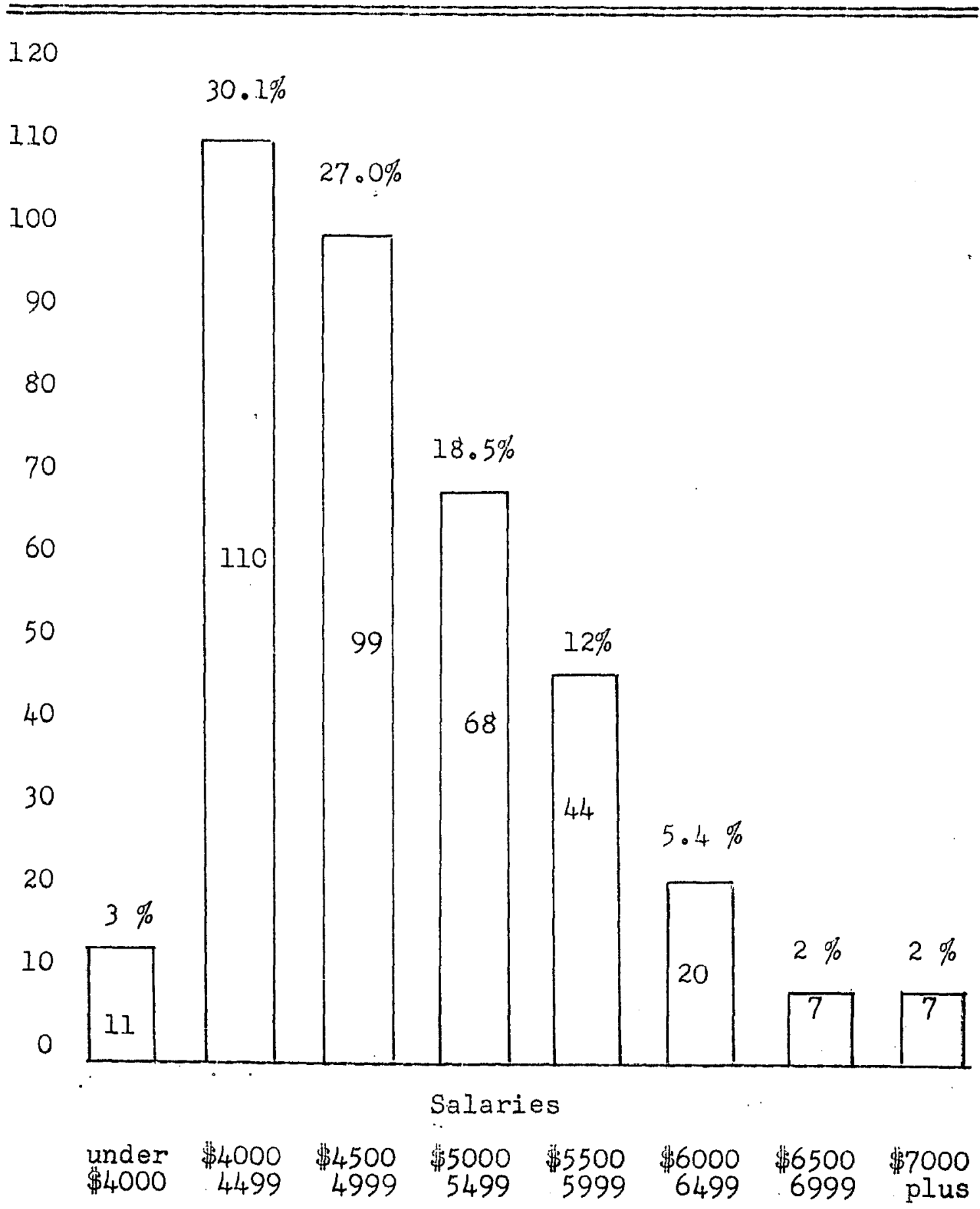


TABLE 46

SALARY RANGE BY SCHOOL SIZE CATEGORIES

\begin{tabular}{lcccc}
\hline School Size & Minimum & Maximum & Median & Average \\
\hline $10-24$ & $\$ 4000$ & $\$ 5250$ & $\$ 4350$ & $\$ 4437.50$ \\
$25-49$ & 3900 & 5600 & 4667 & 4667.54 \\
$50-74$ & 3750 & 5800 & 4400 & 4495.28 \\
$75-99$ & 4050 & 6058 & 4627 & 4723.95 \\
$100-299$ & 3795 & 6972 & 4562 & 4668.69 \\
$200-299$ & 4300 & 5850 & 4775 & 4844.44 \\
$300-499$ & 3850 & 7500 & 5394 & 5378.68 \\
$500-999$ & 4000 & 7400 & 5415 & 5310.60 \\
$1000-2400$ & 4000 & 7400 & 5370 & 5271.43 \\
\hline$=$ & & & & \\
\hline
\end{tabular}




\section{Profile of the Montana Science Teacher}

The data accumulated now make it possible to get a composite picture of the Montana secondary science teacher. He is probably a man- -380 , or 88.2 per cent of the 431 , are male, and only 51, or 11.8 per cent of the total, are women. Figures available from 416 of the 431 studied show that he has taught for an average of about nine years, and is therefore probably between 30 and 35 years old. He has been in the particular school system where he now teaches for about five years (the statistical figure is 4.67), and the "average" science teacher is in a school in the 100-199 size group。 His salary is just under $\$ 5000$ 。

In his undergraduate program the average science teacher shows more breadth than depth. In no one science area in which he is teaching does he show adequate preparation; he is best prepared in the biological field and least prepared in the earth sciences. In general, his background in the physical sciences is decidedly weak.

An analysis of his degree pattern shows 69 per cent with bachelor's degrees, 27 per cent with master's degrees, and 4 per cent either with no degree or not reporting one. In obtaining master's degrees, these teachers have taken very little science on the graduate level.

The number of colleges and universities represented by the 431 teachers studied is astounding. In addition to 
the five Montana schools already mentioned, these teachers have taken work at 79 different institutions of higher education, and, although most of these are in the western and northwestern states, they include schools as far east as Maine, as far south as Texas, and as far north as Alaska. All sections of the country except the southeast are represented. No teacher had listed any work taken outside the United States。

The Montana science teacher is a curious fellow. Whether he comes from outside the state or is a native Montanan, he is a "professional man" who is being asked to do a difficult, almost impossible, task; and he is working under adverse teaching conditions. His reward: sub-standard pay and too often also employment insecurity. 
CHAPTER V

\section{CONCLUSIONS AND RECOMMENDATIONS}

With more than half the world's population politically unfriendly to the United States, with the educational system of a dominant member of this opposition geared to producing a technological society, and with that educational system highly centralized and controlled, the American nation faces a real emergency. Our belief that a major part of the solution to the problem lies in the hands of those responsible for educating a scientifically literate citizenry and for producing our future scientists is evidenced by the amount of money being spent at present, by both private and public agencies, on crash programs designed to strengthen science teaching. The Shell Oil Company, the General Electric Corporation, and the Ford Founation are examples of private agencies expending large amounts for these purposes, while the national government through one agency alone--the National Science Foundation-spends millions of dollars yearly.

A man in a position to recognize the seriousness of the present problem is James R. Killian; now Chairman of the Corporation, Massachusetts Institute of Technology, 
formerly chairman of the President!s Science Advisory Committee, and special assistant to the President for science and technology, 1957-1959. He says, "The fate of the Republic--and even of other free nations--may be determined in the classromms of America. . We must foster and encourage in every way possible a high degree of scientific literacy among people everywhere." 45

Small High Schools

Many Americans accept the tenet that we must retain the type of non-federally controlled educational system we now have, even while trying to solve problems national in scope; this is evidenced by the fact that, in the past, most resistance to a federal-aid-to-education program has been based upon fear of accompanying federal control. However, that much can be done to improve our existing systems without losing or even changing materially our present philosophy of control is shown by various studies in the areas of school size versus efficiency and cost of operation, subjects taught, school facilities, patterns of instruction, and teacher preparation.

One of these studies has been referred to previously: Conant's The American High School Today. It attempts to

45 James R. Killian, Jr., "Education for the Age of Science," NEA Journal, XLIX, No. 2 (Feb., 1960), 11-13. 
show that one of the basic weaknesses in American secondary education is the inefficiency and consequent high cost of operating small high schools. Conant says, "I should like to record at this point my conviction that in many states the number one problem is the elimination of the small high school by district reorganization." 46

Two other studies made in Montana point out the same thing. The first of these is Public Schools of Miontana, a report made on behalf of the Montana Taxation-Education Commission by a team from George Peabody College (referred to hereafter as the Peabody Report). It says:

Procedures and controls should be established which will not only make possible but also insure the consolidation of those small, inefficient high schools which are truly not isciated. Many . . are in operation which are very costly--costly in dollars to the local community; costly in productivity to all citizens of the State because all are beneficiaries of good education; and costly to the individual students affected because of lost educational opportunities. The principle of local autonomy should not be carried to the point where it permits misguided and short= sighted local pride to perpetuate the existence of ineffective school units and to deny, thereby, some youth their right to comgrehensive educational opportunities of quality. 47

The other report, A Study of Ravalli County Public

46 James B. Conant, The American High School Today, 1959; p. 38. (Italics origina1.)

47 Public Schools of Montana, A Report to Montana Taxation-Education Commission, George Peabody College for Teachers, Division of Surveys and Field Services, 1958, p. 169. 
Schools, was made under the auspices of the Bureau of Educational Research and Services of Montana State University。 To quote from the summary of that report, in reference to the secondary curriculum:

The small size of the high schools in the county necessarily prohibits a more effective utilization of teachers within each school. The optimum goal of effective teacher utilization is to have each teacher responsible for instruction in his field, or fields, of major preparation. With the relatively large number of subject offerings necessary to maintain even a minimum high school program and with the relatively few teachers employed in small schools, it is necessary, under present conditions, to assign teachers to fields in which they have little or no preparation. The only alternative which exists to improve this situation under present organization would be to employ an excessive number of teachers which would not be justified from the standpoint of costs to the people of the district. 48

Number of School Districts Should Be Reduced

Obviously, climatic and topographic features of Montana prohibit complete reorganization of its high schools into larger, more effective units. A few Montana high schools are truly isolated and must remain small for an indefinite period, but the machinery to reorganize Montana's school system as soon as possible should be put into operation. Table 47, taken from the Table 4 of the Peabody Report, shows a disproportionate number of school districts

48 A Study of Ravalli County Public Schools, Bureau of Educational Research and Services, Montana State University, 1959, p. 135. 
TABLE $4 \dot{7}$

$$
\begin{aligned}
& \text { NUMBER OF SCHOOI DISTRICTS IN SELECTED } \\
& \text { WESTERN STATES, 1957-58* }
\end{aligned}
$$

\begin{tabular}{lrrrr}
\hline State & Area & Population & Counties & $\begin{array}{r}\text { Number of } \\
\text { Districts }\end{array}$ \\
\hline Arizona & 113,909 & 749,587 & 14 & 307 \\
California & 158,693 & $10,586,223$ & 58 & 1,792 \\
Colorado & 104,247 & $1,325,089$ & 63 & 850 \\
Idaho & 83,557 & 588,637 & 44 & 154 \\
MonTANA & 147,138 & 591,024 & 56 & 1,160 \\
Nevada & 110,540 & 160,083 & 17 & 17 \\
New Miexico & 121,666 & $681,1.87$ & 32 & 96 \\
Oregon & 96,981 & $1,521,341$ & 36 & $700^{* *}$ \\
Utah & 84,916 & 688,863 & 29 & 40 \\
Washington & 68,192 & $2,378,963$ & 39 & 441 \\
Wyoming & 97,914 & 290,529 & 23 & 246 \\
\hline
\end{tabular}

*Peabody Report, p. 45.

**In process of radical reduction through laws of last Legislative Assembly. 
existing within the state; an estimate made by the Montana Taxation-Education Commission indicates that the present 1160 school districts could be reduced to less than 100 . Montana is far out of line with other western states in redistricting. Only California, with a far greater population and somewhat larger area, has more school districts, and consolidation is under way there, too.

Reducing the number of school districts would tend to set up a simpler, more unified system, permitting better planning by replacing the present fragmented and unnecessarily complicated system. Such redistricting, said the Peabody Report, would result in economy: "An abundance of research proves beyond doubt that inefficient school district organization is wasteful. The waste is real, even if other areas are being taxed to support and subsidize the extravagance." 49 Should the amount of money available to schools remain the same, more could be available for improvement had Iontana fewer school districts.

Existing Montana laws make reorganization possible: provision has been made for "merging, dividing and abolishing school districts within a county, and for operating districts in two or more counties. $" 50$

$$
\begin{aligned}
& 490 \text { p. cit., pp. } 48-490^{\circ} \\
& 50 \text { Ibid., p. } 51 .
\end{aligned}
$$


Those who compiled the Peabody Report estimate that it. would be 1982 before reorganization would be completed as long as initiative comes from the local level. Tradition, reluctance to lose local autonomy, misconceptions concerning the status and quality of the small high school, and ignorance of financial structure have all been factors preventing consolidation at the local level. Effective reorganization within a reasonable time apparently must be initiated by the state legislature.

Since this study shows science teaching in the smaller schools to be unsatisfactory because science is often taught by teachers inadequately prepared, since the science courses offered in these schools are insufficient compared to accepted science curricula, since facilities can be assumed to be meager or lacking, since frequent turnover of teaching personnel makes impossible any longrange programs which require careful planning, since teaching assignments in small schools are often unrealistic, and since teachers teaching outside their field of major preparation can be assumed to lack interest as well as training in these imposed teaching assignments, it is therefore recommended that the legislature take immediate steps to consolidate small Montana high schools wherever it is at all practicable. 


\section{Interim Measures}

Meanwhile, several things could help to bridge the gap between present science programs and the more effective ones that could result from consolidation. The same devices might serve to strengthen science teaching in truly isolated areas.

Communities too small to afford a well-trained science teacher or adequate science equipment might consider co-operating to employ a traveling teacher with portable laboratory equipment, who could serve two or more small schools. A refinement of this plan might include teacher assistants to carry out part of the science teacher's duties--thus reserving the use of the master teacher as much as possible for actual classroom presentations. Neighboring communities, city school systems, and even whole counties have shown in other teaching areas that such a plan can be made to work.

The use of certain films, and perhaps in the future the use of educational television programs, could also bring top-notch science instruction on certain topics to schools which for one reason or another might otherwise not receive it. (Let it be clear that this suggestion does not refer to any present use of supplementary visual aids, including films, filmstrips, and other devices, but to films designed to do the teaching job rather than to supplement 
it.) Two such films are now available in the area of the physical sciences: "Introductory Physics," a complete physics course on film, prepared and taught by Dr. Harvey E. White of the University of California, and produced by Encyclopaedia Britannica Films, and "Modern Chemistry," a year-long chemistry course produced by Learning Resources Institute. The use of closed-circuit television for schools has already enjoyed wide trial use in certain parts of the country and may eventually help solve some of the problems of the nation's isolated schools.

Curriculum Can Be Improved

When data regarding the science curricula of ivontana schools is analyzed, one wonders whether much thinking or planning precedes the inclusion of a science subject. Many teachers in the small high schools are hired less to teach particular subjects than just to teach: witness the number who are teaching science without preparation. The large turnover in personnel each year shows that long-term curriculum planning is unlikely; and not only do science teachers change frequently, but administrators in small schools are seldom retained long enough to develop school programs that require long-range planning.

Lack of uniformity in science offerings in. Montana is apparent from analysis of the data that have been pre- 
sented: some schools offer no general science, some no biology, some no chemistry, and some no physics. In some cases a subject or subjects are offered if a teacher is available to teach them, if the teacher agrees to teach assigned subjects when asked to do so (regardless of his preparation), if such subjects fit into the school curriculum, or if the administrator and school board think the subjects should be included.

If the English historian, C. Northcote Parkinson, is correct when he says that "the potential war strength of a country might be measured by the number of its scientists, "5I the schools described are not doing their part to meet the emergency which exists today. To have a science curriculum which is determined more by the potentiality of a transient teacher than by careful planning to meet the needs of the students and the society of which they are a part is inefficient--and could lead to disaster. It would seem much more desirable to reverse the process and secure teachers who would suit a curriculum which has been carefuliy planned.

Two obstacles in particular make the setting up of such a curriculum very difficult: many teachers are unable

${ }^{5 I_{C}}$. Northcote Parkinson, "Can Democracy Survive?" Saturday Evening Post, Feb. $6,1960, p_{0} 45$. 
to do the job required because they have weak backgrounds in science, and curriculum committees set up on a local or a state level, even though composed of competent individuals, work under the twin handicaps of lack of time and lack of energy. Much of the work assigned these committees must be done after school hours or on weekends. Since intellectual productivity is directly related to time and energy, the most that usually occurs in these committees is a reworking of the existing curriculum.

\section{A National Science Curriculum Center}

Any curriculum deserves much thought and careful planning by thoroughly competent individuals. In a field like science, where the quantity of accumulated knowledge is great and where such knowledge is constantly changing, high school science teachers are not easily able to sort out what should be taught. Perhaps no one can really do it, but it seems reasonable to assume that highly selected individuals, working continuously with sufficient facilities, could do a better job than an ill-prepared teacher with insufficient time.

It is therefore recommended that a committee of competent individuals be selected on a national basis, paid with federal funds, and housed in a well-equipped science curriculum center. The membership could represent all 
levels of our educational system, and a staggered plan for rotation of membership could be used. The material coming out of such a science curriculum center could be disseminated for discussion at annual meetings of such existing organizations as the American Association for the Advancement of Science, the National Science Teachers Association, the National Association of Biology Teachers, the National Association for Research in Science Teaching, and others. Finally, such material could be transmitted to state and local curriculum committees to guide their science program planning。

Science curricula should be fluid, with provisions for continuous additions and deletions, but some standardization of content might be desirable--possibly 60 per cent standardized and 40 per cent locally oriented. To those who might object to such standardization on the grounds that it smacks of regimentation, it can be said that such regimentation exists today, but it is determined by the content of the various secondary science texts available.

Resource Units

It is obvious that a curriculum subject to continuous revision could not be taught from existing textbooks, which are often obsolete by the time they are published. If resource units could be prepared and if the science 
teacher could teach from them, their flexibility would promote better science teaching. Sufficient references available for the students would also be needed--original source material and technical material interpreted for the high school level, housed in a good high school library.

Formal education should be more than a process designed to disseminate much soon-to-be-forgotten factual information; it should be a method for starting an individual on a continuous leaming program, and a plan using a flexible curriculum and resource units is a more natural method of learning than the textbook-recitation method now in use.

Shaler, who worked with and succeeded Agassiz at Harvard, said of textbooks:

The textbook is far worse than worthless, for almost all the purposes which the teacher of zoology should have in view. . . But in proportion as these exceptional works are good as encyclopedias they become worthless as textbooks: as they grow more valuable for reference, they become less suited for the purposes of cramming. But the mass of text-books which infest the path of the student of nature are, in their methods, utterly vicious, and in the highest degree calculated to root out the scientific spirit from the unfortunate student who may be so unhappy as to work with them; moreover the body of fact which they contain is generally that which belonged to the science of several decades anterior to the date of their publication. The growth of our sciences is so rapid that it is not possible to stereotype even its outline. The best textbooks I know were antiquated before they went to press.52.

$52_{\text {Nathaniel S. Shaler, "Natural History Education," }}$ 
Herbert Spencer, referring to books generally, said:

Not recognizing the truth that the function of books is supplementary--that they form an indirect means to knowledge when direct means fail--a means of seeing through other men what you cannot see for yourself, they are eager to give second-hand facts in place of first-hand facts. 53

Furthermore, secondery science texts are primarily commercial enterprises; they are not always written by scholarly individuals or by those professionally close to secondary teaching. Yet some available text must, by law, be furnished pupils in Montana, as in many other states. Unless there is a requirement to change these texts frequently, lack of funds at the local level often results in the use of outdated texts.

Paperbacks may prove to be a partial answer to the textbook problem, since texts will probably continue to be used in some form for some time. We could produce paperbound texts priced reasonably enough to pernit a return to pupil-owned texts--expendable, and renewed each year. This in turn would permit the use of up-to-date texts. A recent feature in the Saturday Review outlines some good and bad points of paperbacks, according to high school teachers who have used them:

Addresses and Journal of Proceedings of the N.E.A., 1872, at Boston, Mass., pp. 232-239.

53 Herbert Spencer, Education, 1860, p. 46. 
Those who have introduced paperbacks successfully into their classrooms cite the economy, the attraction of students to paperbacks, the fact that students can take notes in their books, and the excellent introductions. On the other hand, teachers who do not recommend paperbacks list among their objections sinall print, objectionable covers, and weak bindings. 54

Content Needs Revision

Another phase of the secondary science curriculum which should be considered is that of content. The increasing emphasis on science in the elementary school has made it necessary to examine the high school science program for possible unnecessary repetitions, and there is much evidence to indicate that the fragmented, non-integrated science courses now in existence are not serving current needs.

First, the existing science program in ivontana (and in the nation) is not reaching or challenging tire majority of high school students; it therefore has little value as far as general education is concerned. Second, spokesmen for industry have long contended that they prefer high school graduates to have good grounding in English and mathematics rather than specific knowledge in any particular science area. Third, high school physical sciences are often not meeting the needs of the college-bound

\footnotetext{
54 "Pick of the Paperbacks," Saturday Review, Feb. 13, 1960, p. 30 .
} 
student, for many professors in the physical sciences prefer students to come to them without having had high school chemistry or physics。 Furthermore, as Burnett points out, there is poor correlation between achievement in high school chemistry or physics and college success in the same subjects, but high correlation between average high school marks and college achievement in science subjects. 55 Most of the science subjects now being taught in our high schools were introduced into the curriculum back in the last century, but they lacked academic status until 1872, when Harvard accopted physics as a college entrance subject. Science as a part of general education was not considered important, and the high school population was a much more select group than it is today. At present, with different ressons for the inclusion of science, with a less select student body, and with a greater practical need for teaching science, we still retain much the same content and organization.

If the need for a scientifically literate citizenry and the needs of the potential college student are both to be met, we must broaden and integrate our sicondary curriculum. Paul Sears says:

Another remnant is the conventional limit of one

55 Will Burnett, Teaching Science in the Secondary School, 1957, pp. 87-8. 
required course in one field of science. This limitation completely ignores the fact that no one science can give wholeness to our understanding of the physical world in which we live.

We must then admit that science has been intro $\overline{5}$
aced imperfectly into our scheme of education.

General Education in a Free Society (the Harvard

Report) recommends:

Science instruction in general education should be characterized mainly by broad integrative elements--the comparison of scientific with other modes of thought, the comparison and contrast of the individual sciences with one another, the relations of science with its own past and with general human history, and of science with problems of human society. - . Below the college level, virtually all science tyeaching should be devoted to general edu-

How might this reorganization and integration be accomplished in Montana? Science content might be rearranged into the two broad areas of physical science and biological science, and be set up so that a one-year course in each area would be required of all high school students. Each area could be expanded to a second year of work, so that those with aptitude and interest might have the opportunity to take three or four years of science. Support for this recommendation is found in a recent publication of the

56 Paul B. Sears, "A Science Curriculum for Teacher iducation," College and University, XII, No." 4 (Nov. 15, 1959), 1.

57 Harvard Committee, General Education in a Free Society, 1952, pp. 155-156: 
National Science Teachers Association:

A physical science course makes for economy of time not obtained when separate courses in physics and chemistry are given. It eliminates duplication in a number of topics such as atomic structure, the states of matter, the gas laws, chemical reactions, valence, and electricity。

In addition, learning studies seem to indicate that immediate and delayed retention for strong physical science courses is greater than for traditional chemistry and physics courses taken as a two-year sequence. Both of these advantages in favor of physical science point to it as a substitute fog chemistry and physics courses in many high schools. 58

For students in systems having a three-year high school, the basic physical science course should be taught in the ninth grade of junior high. It is recommended that biological science follow physical science because a sound knowledge of living processes depends upon a good foundation in physical science, and also because life sciences should be approached from as mature a level as possible. The trend now apparent in Montana to put biology into the ninth grade should be reversed.

Both physical and biological science should be taught with more than a "book" approach: in the words of the Harvard Report, "students should be led to explore matters for themselves and to find answers to simple prob58 New Developments in High School Science Teaching,
National Science Teachers Association, $1960, p_{0} 63$. 
lems by direct experimentation." 59 To do this, better laboratory work is needed. Laboratory experiences in many Montana schools have been curtailed or missing; one reason is that the traditional arrangement of three single-period recitations and two double-period laboratories a week makes scheduling difficult--especially in smaller schools, where faculty and course offerings are limited. Anather reason is financial: science laboratories are expensive, and schools operating on limited budgets may eliminate them. A third reason may be an experience of abuse or misuse of laboratory facilities and equipment by untrained or careless teachers. We need to study high school laboratory procedures to find methods for making them more effective. One way surely would be to orient future science teachers to desirable high school laboratory practices during their training program. The laboratory experiences of college science courses are inadequate for future teachers.

\section{The Junior High School}

One more aspect of the science curriculum that especially needs study in Montana is the area of the junior high school, and of the seventh and eighth grades in particular. We need to try to determine both its direction

$$
\text { 590p。cit., p. } 157 .
$$


and its function, for at present there is the greatest disparity in every aspect of the seventh and eighth grade science program: content, scheduling, facilities, and teacher preparation.

According to the Peabody Report, many junior high problems stem from lack of unity in school organization patterns: "The confused status of Grades 7 and 8 is highlighted by the regulation of junior high schools through inconsistent statutes. Articulation between all grades is essential." 60 The seventh or eighth grade science teacher is caught in this confusion; sometimes he has a self-contained classroom where he is responsible for all or almost all the instruction; in systems where teaching is departmentalized in varying degrees he may be responsible for not more than one or two subject areas.

Teacher Preparation

The data presented in Chapter IV seem to leave little doubt that many who teach science in Montana (and elsewhere) are not well prepared for the task they are supposed to do. Contributing factors include the size of the school, administrative convenience, teacher certification, accrediting procedures, and the professional training of the

60 Public Schools of Montana, Montana Taxation-Education Commission, 1958, p. 48. 


\section{teacher.}

Improving school size by consolidation has already been discussed; this basic step needs to be taken, but it will not automatically produce substantial improvement in the teacher's preparation. The geographical features and small population of Montana negate the possibility of consolidation's producing high schools of the size Conant considers optimum. Rather, consolidation in Montana will eliminate very small schools and produce more middle-sized schools. These schools, enrolling from 200 to 500 pupils, are already the most numerous not only in Nontana but throughout the country; these schools, therefore, share many common problems.

In small schools the science teacher usually has one science class as a part of his total teaching load. In large schools he may be teaching several classes of one science subject, or perhaps two, and nothing else. But in the middle-sized schools one teacher is often responsible for all science courses that are offered. It is almost impossible under present training patterns for an individual to acquire enough background in all science areas to do a satisfactory job, and it is for this reason that other changes besides consolidation must occur. Consolidation without concurrent changes might even aggravate an already bad situation。 
If the broad-fields approach in high school science is accepted, it will require separate teachers for the physical and biological science fields, regardless of school size. Only if the undergraduate training program is lengthened could one teacher be adequately prepared to handle both.

Certification Requirements

There are times when, for one reason or another, an administrator considers it necessary to assign a teacher classes in a subject for which he has inadequate preparation. Such a situation should not be countenanced, and administrative machinery on the state level should exist to prevent it. The requirements for accreditation of a school theoretically prohibit such a practice but actually are not effective, as is evidenced by the number of those teaching science subjects without adequate preparation. Either more stringent laws need to be passed or existing certification requirements need to be better enforced. At present (195960) three Montana schools have been refused accreditation, seven have been approved with warning, twenty-two approved with advice, and eighty-one approved with comment. Thus, 113 Montana schools have been officialiy noted as falling short of the state's standards. As far as the teacher is concerned, a flagrant 
contradiction exists between certification requirements and the conditions which he finds in actual teaching assignments. In preparation for teaching he met definite rules for state certification by which he must abide: a definite number of hours to complete teaching major and minor requirements, with required courses, all quite rigidly adhered to. He must wonder, then, why this insistence on the part of the state to rules that governed his preparation for teaching, since both state-level and local administrators apparently disregard patterns, or lack of them, in the teachers actually employed.

Teacher certification requirements differ markedly in various states. Table 48 is introduced to show differences existing throughout the country in requirements for science teaching. These requirements, for 14 states selected at random for comparison with Montana, were those listed in the brochures and pamphlets issued by the various state departments of public instruction.

In some states the number of hours required to teach a particular subject are spelled out in some detail; at the other extreme are states (not included in the tiale) where nothing is specified about the number of hours of preparation required to teach in specific fields. The study printed by the Harvard Summer Conference reports that "in 29 states, it appears to be possible to be certified to 
TABLE 48

CWRTIFICATION REQUTREMENTS FOR SCIENCE

TEACHERS IN FIFTEEN STATES

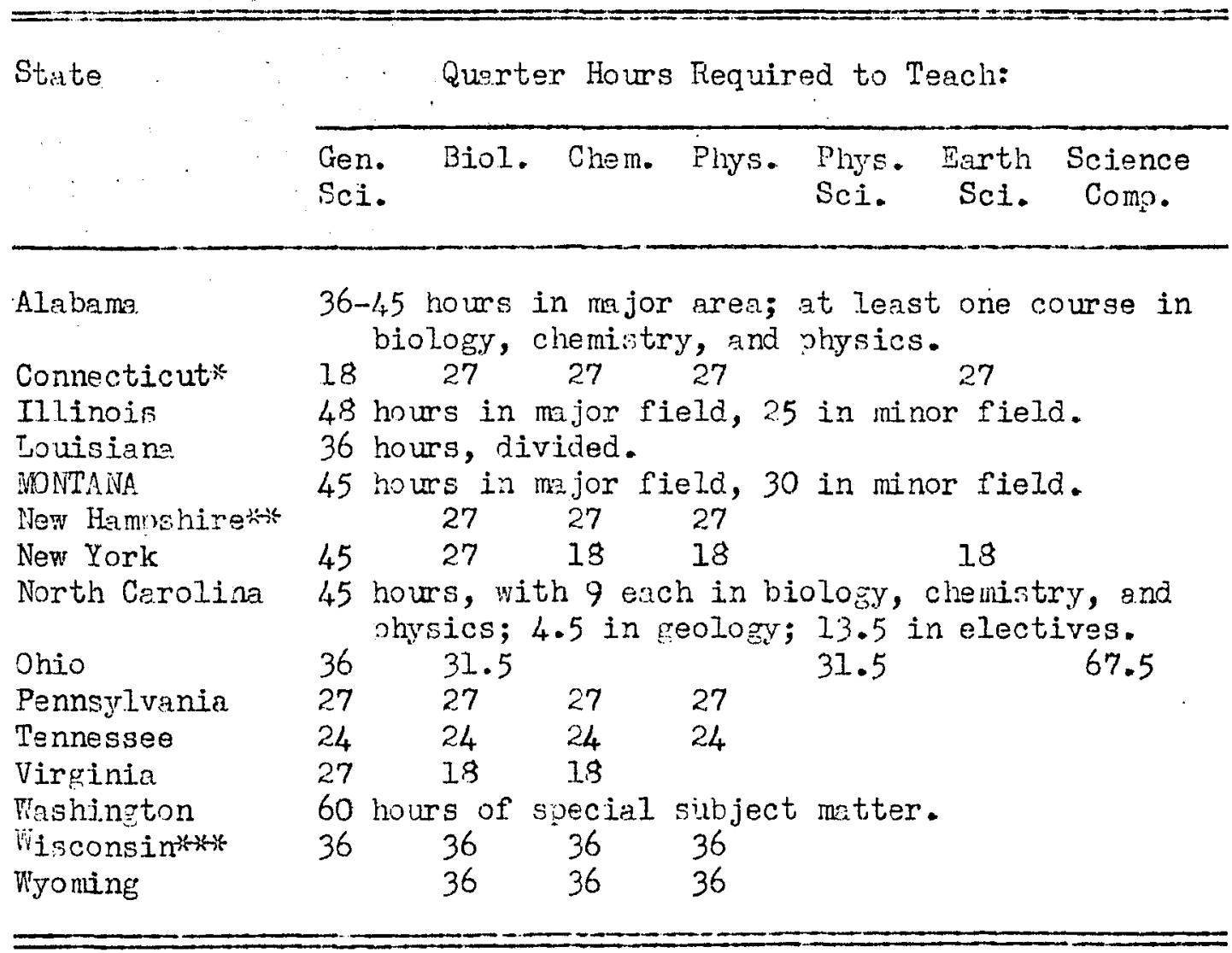

* Connecticut requires at least one course in three fields for general science teschin:; 18 hours in a second science area.

** New Hamphire requires a 9-hour minor for teaching one or two periods only.

*H* Wisconsin requires 22.5 hours for teaching science in grades 7-9. 
teach in one science field without having college credit in any other science." 61

In Montana the number of hours required is specified, but the interpretation of what constitutes teaching majors and minors is left to the teacher-training institutions to decide. Physical science and biological science majors and minors exist in Montana, as well as majors and minors in specific fields such as chemistry. If there is agreement that the number of hours required in a teaching major constitutes the minimum necessary to acquire enough background and understanding to do a satisfactory teaching job in that area, then teaching minors fail to make academic sense. Yet many science teachers in Montana carry majors in fields far removed from science and are teaching science with a minor only。

Table 48 shows a wide variation in certification requirements in the states surveyed--a variation which should be reduced. State directors of certification and others interested. in the subject, meeting in Salt Lake City in April, 1960, suggested that the teacher-training institutions cooperatively set the standards for certification of science teachers. It was recommended that the states 6IFletcher Watson, Paul Brandwein, and Sidney Rosen,
eds., Critical Years Ahead in Science Teaching, Report of Conference on Nation-Wide Problems of Science Teaching in the Secondary Schools, 1953, p. 27. 
abrogate their prerogative in this area to these institutions and accept the resulting standardization; if this could be done, a more uniform pattern of certification could result. It would be more feasible for teachertraining institutions to do this than for the states to try jointiy to adopt a program acceptable to all.

In Montana, for example, the undergraduate courses required of the prospective science teacher are determined by the various colleges, and there exists no uniform pattern of preparation. Until some degree of national standardization is achieved, it would be well if the education and science departments of state teacher-training institutions would cooperate to work out a more uniform pattern. For instance, Montana State University's elimination of a science minor without an accompanying major in either science or mathematics might be extended to the other schools in the state.

\section{Science Courses Specifically for Teachers}

Since some unprejudiced studies have shown that traditional science courses do not furnish adequate background for the high school science teacher, this evidence should be examined and "tested." The science courses of pre-medical and pre-engineering curricula, for example, are largely determined by the needs of these special fields, 
and the prospective science teacher is too often forced into such courses with the assumption that they will also give him an adequate science background for teaching. The training of teachers should be much more basic and unspecialized than the training of technologists, and the pattern of their training should be determined not by chance or convenience but by careful study on the part of individuals willing to lay aside any particular academic bias and to approach the problem objectively.

Five-Year Training Program Desirable Some states (New York and Washington, for example) have recognized that the present four-year training period is not long enough to prepare science teachers, and Critical Years Ahead in Science Teaching gives the following as one of seven general recommendations drawn from twenty recent studies concerning science teacher-training and certification programs: "The five-year college training program for teachers [should] become a mandatory minimum." 62 Why is five years' training necessary? For one thing, it is not unreasonable to expect double majors from science teachers, considering what they will be asked to do. For another, a supporting knowledge of mathematics

$$
62_{\text {Ibid. }}, \mathrm{p} .40
$$


through calculus is necessary for fundamental understanding, particularly in the physical sciences. There seems little question that the minimum period for accomplishing this much would be five years. Provisional certification might be granted after four years, but complete certification should be withheld until the fifth year is completed. Some critics blame the weaknesses in academic backgrounds on the number of professional education courses that the high school teacher is required to take, but since it is possible to be certified in Montana with only 24 quarter hours of professional credits, or approximately 13 per cent of all undergraduate work, this is obviously not the only reason for inadequate training in science.

\section{Summer Offerings for Science Teachers}

Whether or not a longer period of training is accepted as necessary, it would be helpful if our college summer school programs included more science course offerings, especially at the intermediate level。 If a fiveyear program is adopted this will be a necessity. Summer school budgets are small in the smaller colleges and universities, and at present summer science courses are often limited to those which can be taught by the one professor whose turn it happens to be to teach for the summer session. Typical offerings may be the basic courses and 
perhaps a few very advanced courses designed primarily for those planning to specialize in the science concerned.

A solution for areas like lMontana might be to concentrate the summer's science efforts in one school in the state (not necessarily the same one each year) and, if necessary, make it possible for the student to get credit in his own alma mater. Another solution would be science institutes financed by federal grants; but at present the awarding of such grants carries no certainty of continuation beyond a single summer or academic year, and it is therefore impossible to plan any long-range program of improvement. If such federal aid programs are to be other than fragmentary, stop-gap devices, they need to be organized on a different basis.

\section{Graduate-Level offerings}

Supplementing the five-year undergraduate training should be a concinuing program at the graduate level. which would permit the student to take work in the sciences as. well as in education. Science teachers often should be steered out of administrative courses into graduate science programs, and courses at this level should be organized with the needs of the high school teacher in mind. Since many now teaching science are deficient in subject matter, especially in supporting sciences, a graduate program might 
permit such teachers to take basic undergraduate courses in lieu of, or for, graduate credit. The Master of Arts in Teaching now offered by many universities is a degree which encourages such a program at the graduate level; Yale University's program, for example, makes special provision for those who show weakness in a science area. To quote from Yale's brochure: "Occasionally [the student] may take an undergraduate course with extra work that meets a graduate standard. In every case it is a major concern of the Program to ensure sound training in the student's subject matter iield." 63 Although this particular provision has been recommended by the National Academy of Science and by other scientific groups, it is very difficult to have it approved by university graduate committees.

Suggested programs for the training of high school science teachers are included in the appendix, abstracted from a report of the AAS Cooperative Committee on leaching of Science and Niathematics. 64 These recommendations represent the sustained effort of a number of competent individuals. However, all the committee members are teaching on a college level, and before their recommendations are accept-

63 viaster of Arts in Teaching, Yale University Graduate School, 1956-1957, pp. 7-8。

64 "recommendations for the Preparation of High School Teachers of Science and Mathematics, "mimeographed report in progress, n.d. 
ed they should be reviewed by a committee of high school science teachers meeting with the AAAS committee.

Salaries Need Improvement

One real difficulty in the graduate training of science teachers is financial. This study has shown that Nontana's science teachers are usually men, often underpaid。 Narried men with families often take graduate work in administration so that they may get higher administrative pay; otherwise, they may find it necessary to work in the summer to eke out their salaries. The only way we can overcome this obstacle will be to pay our science teachers better, or to organize some more permanent subsidized training program for science teachers, or both.

In conclusion, then, this study was undertaken to present material from one state which is pertinent to the general problem of science education. Interpretation of the facts presented shows that it would be possible to greatly improve that phase of our educational program which deals with secondary science without materially altering our basic educational philosophy. 
APPENDIX A

FORM A REPORT

$-176-$ 
ASO

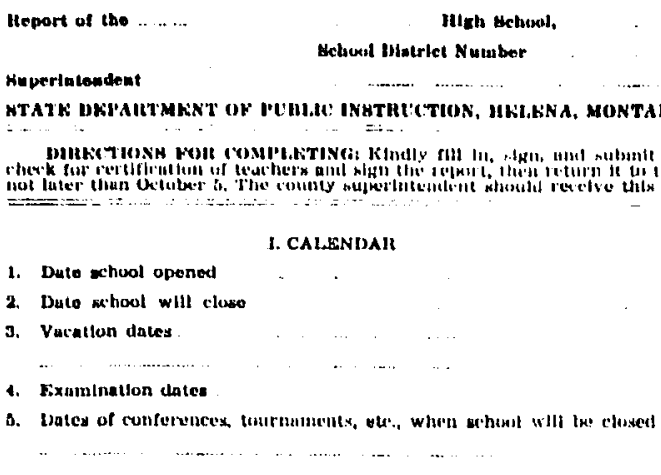

\section{ACCIEDITINO}

1. Veitrs accredlleng arantent lasel year

2. Ageney Rratiling ateredlistlon

State

negianal

3. No. krueles dauglle in 11. S. thls year

t. No, years aceredlung nowght this year

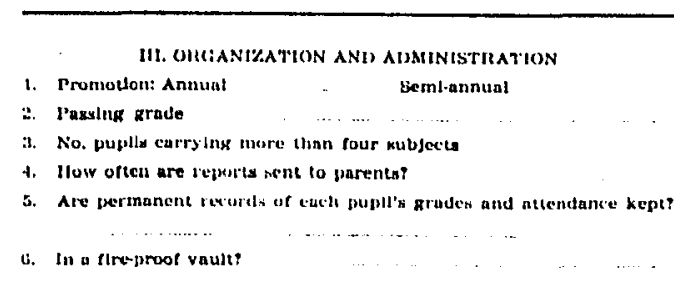

G. In a tira-proot vault?

IV. ENROLLMENT

Folt JUNIOH HIGI SCHUOLS:

1. No. pronoted from Gruile da last epring

2 Septembir enrollment hat yonr

Gracle 7: boys ........ Girls ... ... Toru

Grade 8: Boya .... ......... Girk

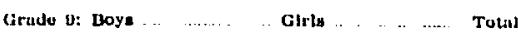

Totals

FOIt 4-YEAR AND SENIOR HGH SCHOOLS

If sunlur htgh bchool, omit Items 1, 2, 3n.

1. No. Grode 8 graduates last yoar...

2. No. these now in hlgh wchool...

3. A. Grade 0; Boya ................. Girls

b. Gracle 10: Hoys _ Glrls

c. Grade 11: lloys _ _... Girts

d. Gracte 12: hoys $\quad$ Girls

e. Spectal: Boryy ... ... Girla

e. Fost-tirud: Hoya

g. Tolal Equollment:

BOY:-
URLIC JUNIOR COLLEGE

Girle.......

Grade 13: Hoys.

Gracle 14: Boys

Total

- Irelualpal

Moncinan.

(II not cunaty litah nchooul).

County.

, to tus

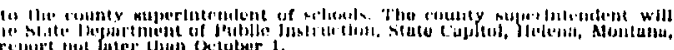

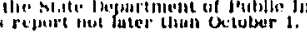
v. LIHแล

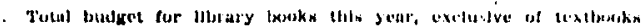

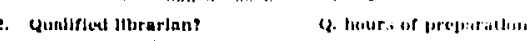

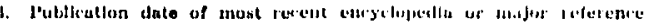

VI. THACHEL THML:

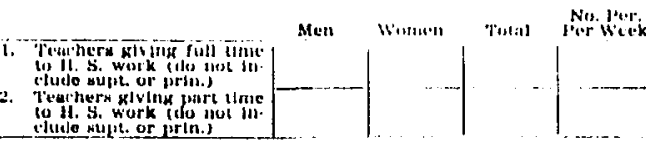

2. Tearhers glvinu part

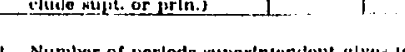

a. Iligh sellool kupervinion

b. Hish wehosl clusu work

s. study hall work

c. Admindatratlve dutlew

s. Number of meriuda princlyal atven to:

a. Itigh Sithoul supervition

11. IIIgh school cluss work

$\therefore$ Sictity hall work

d. Adminlstrative dutles

3. Were all setchers employed upon the recummendutlon of the prin. C.juil, superintendent, or county superintendtint"

(i. It not, why not?

7. Simber of teucherk who did nut tench last year:

1. Number minutes per week devoted to clistev In heaith in tiuction (not P. E. or athlet/cs): Loys

VII. HEALTII

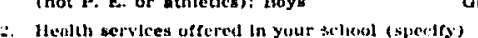

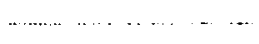

VIII. BONHU OF EDLCATION

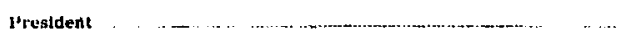

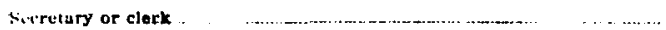


Proparation and Cortifleation of Teachere

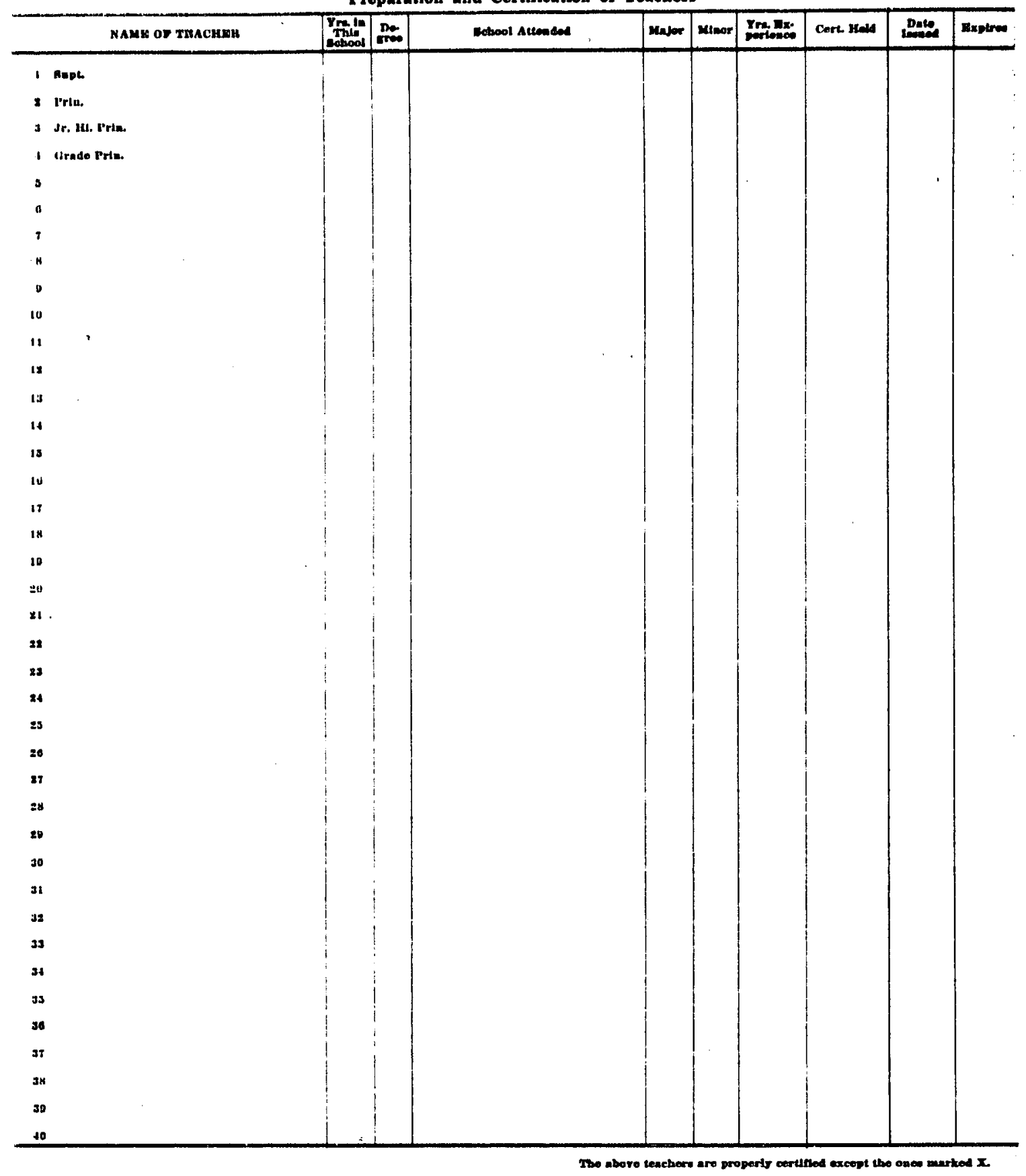




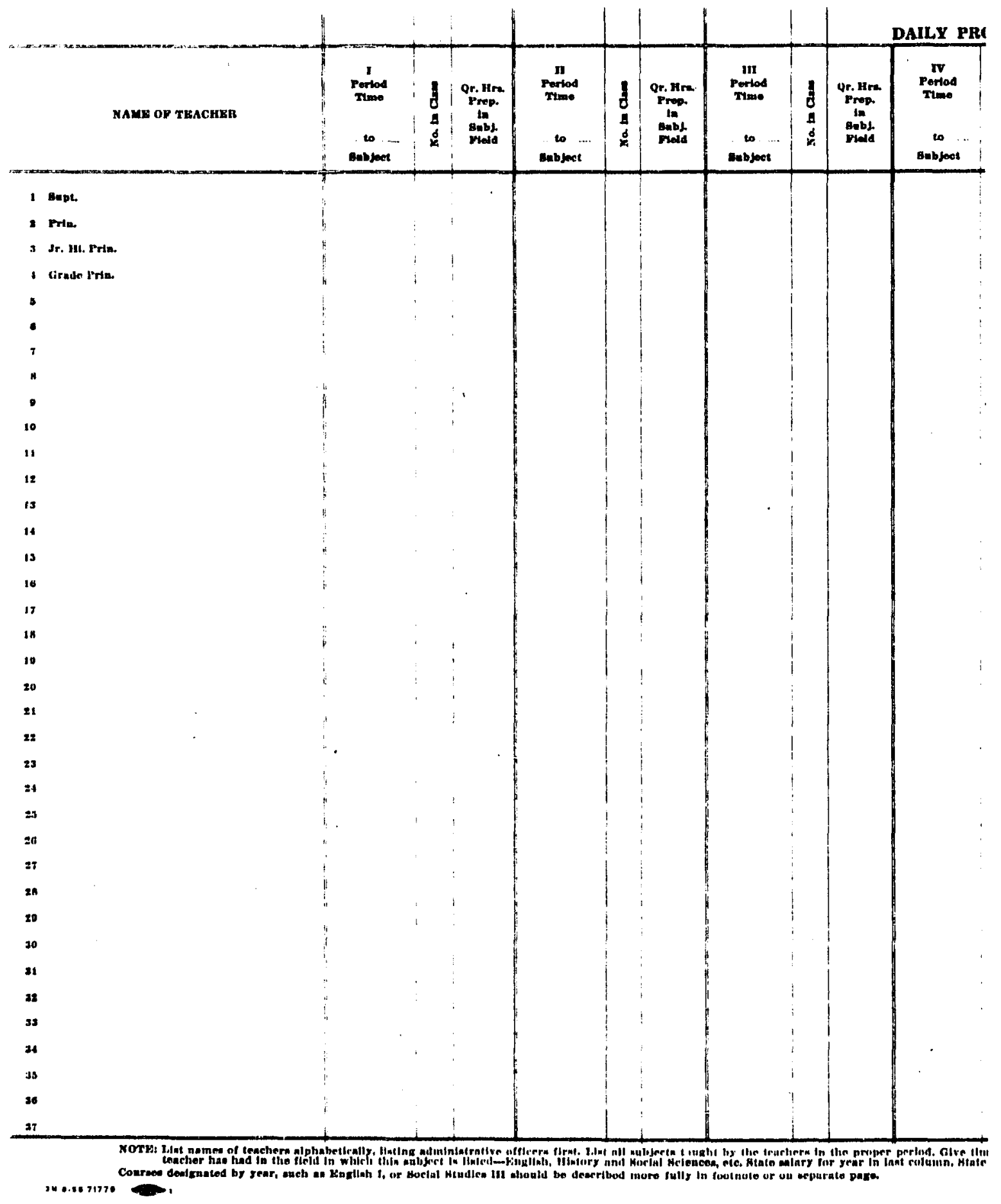




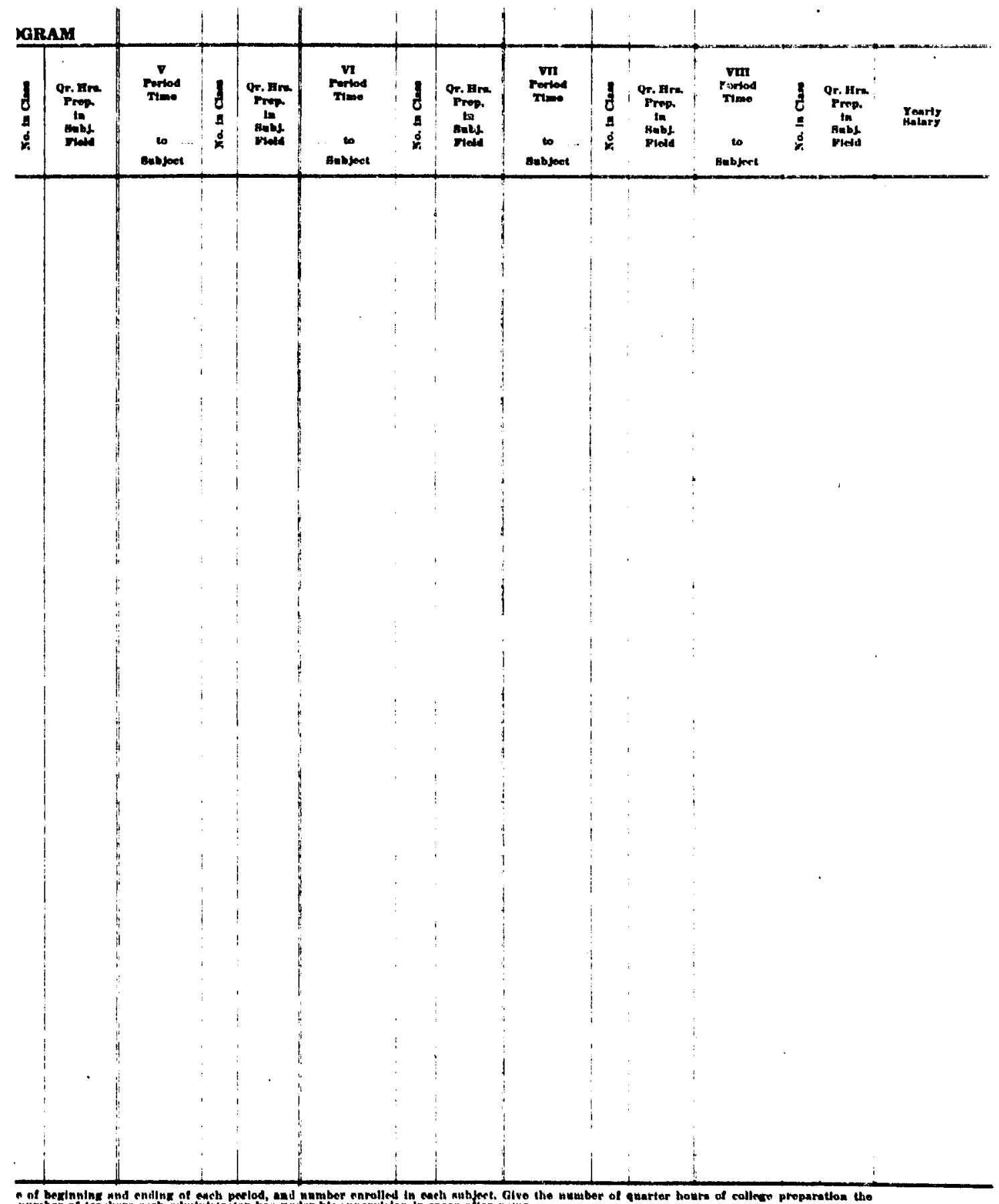

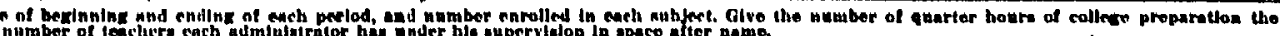




\section{APPENDIX B}

SAMPLE CURFICULA FOR THE PRPPARATION OF HIGH SCHOOL SCIENCE TEACHERS, TAKEN FROM REPORT NO. 5 OF THE AAAS COOPERATIVE COMMITTEE ON TEACHING OF SCIENCE AND MATHEMATICS

Suggested Courses in Physics and Other Sciences for the Preparation of High School Teachers of Physics

PIan I and II (given in semester hours)

\begin{tabular}{|c|c|c|c|c|c|c|c|}
\hline Wajor & $\begin{array}{l}\text { Teaching Field } \\
\text { Physics }\end{array}$ & A & B & C & D & ( 4 Total & $\begin{array}{l}\text { Fifth } \\
\text { Year }\end{array}$ \\
\hline \multicolumn{2}{|c|}{ Physics } & $8-10$ & $6-8$ & $4-5$ & 2 & $20-25$ & 15 \\
\hline \multirow{4}{*}{ 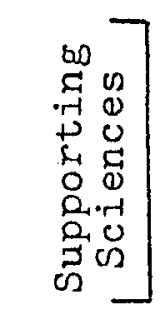 } & Chemistry & $8-10$ & $5-10$ & & & $13-20$ & 10 \\
\hline & Mathematics & $8-10$ & $5-10$ & & & $13-20$ & 5 \\
\hline & Biology & $6-10$ & & & & $6-10$ & \\
\hline & Earth Science & $3-5$ & & & & $3-5$ & \\
\hline \multicolumn{2}{|c|}{ Total } & & & & & $60-62$ & 30 \\
\hline
\end{tabular}

NOTES:

Physics A. Introductory course in College Physics to cover the conventional areas of mechancis, sound, heat, electricity, magnetism, light, and some aspects of modern physics. Problem work and laboratory experience should make up at least half of course activities.

Physics B. A second year course; a composite of the advanced courses in heat, light, and electricity especially 
planned for the needs of the secondary teacher of physics. Emphasis should be on a thorough treatment of a limited number of concepts and principles in these areas. Experiences should be provided in planning experimental demonstrations and laboratory work associated with these concepts and principles. The usual courses in advanced light, etc., may be substituted in the absence of such a course planned for teachers.

Physics C. Modern Physics, the phenomena, concepts, and experimental techniques of modern atomic and nuclear physics using mathematics through calculus. At least $25 \%$ of the course should be laboratory experience.

Physics D. Techniques of Physics Teaching. The methodology of classroom and laboratory means of instruction offered by the physics department.

Chemistry A. General Chemistry and Qualitative Analysis. Chemistry B. Organic I and/or Physical.

Mathematics B. Calculus.

Biology A. Basic Principles of Plant and Animal Life. Earth Science A. Any course in the earth science area, e.g., geology, meteorology, astronomy, or any combination thereof.

Plan I is for those teachers planning to teach physics only; this would amount to student taking the maximum of hours in physics and the minimum in the other subjects.

Plan II is for those teachers planning to teach physics and one or more of the other subjects; they would take the minimum in physics and the maximum in those other areas in which they expect to teach.

It is the consensus of the committee that there is very little need for Plan I since there are few "physics teachers." Plan II is more realistic or perhaps a program for the "physics-chemistry" teacher or "physical science" teacher should be formulated. 


\section{Suggested Courses in Chemistry and Other Sciences for High School Teachers of Chemistry}

(Given in Semester Hours)

\begin{tabular}{|c|c|c|c|c|c|c|c|c|c|}
\hline \multirow[t]{2}{*}{$\begin{array}{l}\text { Major Teaching Field } \\
\text { Chemistry }\end{array}$} & \multicolumn{6}{|c|}{ Chemistry } & \multicolumn{3}{|c|}{$\begin{array}{l}\text { Supporting } \\
\text { Sciences }\end{array}$} \\
\hline & $\begin{array}{l}-1 \\
0 \\
0 \\
0 \\
0-1\end{array}$ & 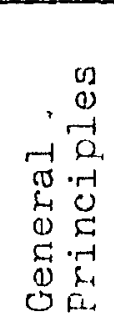 & 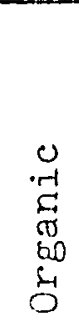 & 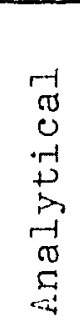 & 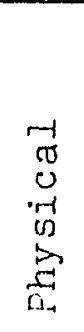 & 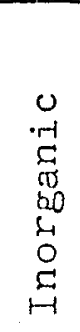 & 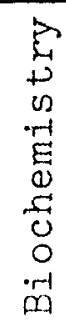 & 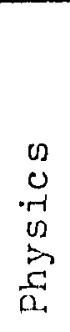 & 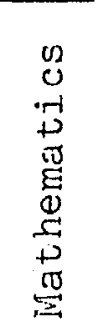 \\
\hline Chemistry Major SHS & 32 & 8 & 8 & 4 & 8 & 4 & & 8 & 12 \\
\hline Chemistry Minor SHS & 16 & 8 & 4 & & & & & 8 & 8 \\
\hline $\begin{array}{l}\text { Additional Major } \\
5 \text { th Year }\end{array}$ & 16 & & & & 8 & 4 & 4 & 8 & 8 \\
\hline $\begin{array}{l}\text { Additional Winor } \\
5 \text { th Year }\end{array}$ & 20 & & 4 & & 8 & 8 & & 8 & 8 \\
\hline
\end{tabular}

\section{NOTES:}

Descriptions of Course Areas: The organization above does not mean that there will be courses exactly divided as the figures in that table. It indicates the general proportion in terms of semester hours. Also, the descriptions below do not mean that all topics must be included, nor that others could not be; they are merely illustrative and possible topics.

General Principles: Composition and structure of matter, atomic and molecular theory, state and transitions of matter, stochiometry, nature of solutions, periodic tables and relationships, rates of reactions and equilibrium, ionic equilibrium and properties of electrolytes, oxidation-reduction and electrochemistry, energy relationships and colloidal state. 
Organic: Nomenclature, hydrocarbon series, functional groups and their basic reactions, typical methods of preparation, application.

Analytical: Gravimetric and volumetric and instrumental methods and their applications and limitations.

Physical: Determination of precise physical properties and the application of this data to problems of reaction rates, equilibrium systems and structure determinations.

Inorganic: Relation of structure to properties, periodic system, typical reactions, and the application of physical chemical principles to inorganic systems.

Biochemistry: Fundamental reaction systems of living organisms.

Note: It is hoped that the prospective teachers will have a course in the design and operation of a laboratory at the high school level. It is assumed that they will have one year of biology. 


\begin{abstract}
Suggested Courses in Biology and Other Science for the Preparation of High School

Teachers of Biology
\end{abstract}

\begin{tabular}{|c|c|c|c|c|c|c|c|c|c|}
\hline \multirow{2}{*}{\multicolumn{2}{|c|}{ 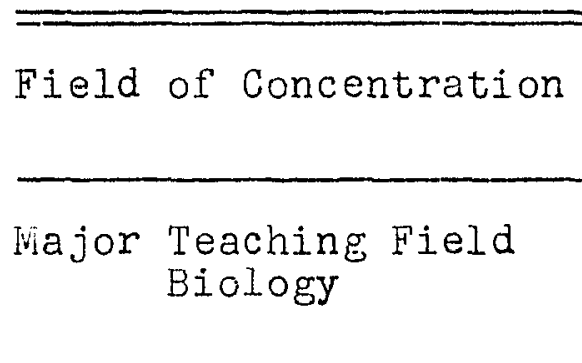 }} & \multicolumn{6}{|c|}{$\begin{array}{c}\text { Undergraduate Course Areas } \\
\text { (4 years) }\end{array}$} & \multicolumn{2}{|c|}{$\begin{array}{l}\text { Fifth } \\
\text { Year }\end{array}$} \\
\hline & & $\begin{array}{l}\text { Approx. } \\
\text { Sem. Hrs. } \\
\text { (Total) }\end{array}$ & A & B & C & $D$ & & & $\mathrm{~F}^{*}$ \\
\hline \multicolumn{2}{|l|}{ Biology } & 30 & 10 & 8 & 4 & 4 & & & $12^{*}$ \\
\hline \multirow{4}{*}{$\begin{array}{ll}0 & \\
0 & 0 \\
0 & 0 \\
0 & 0 \\
0 & 02 \\
0 & 0 \\
60 & 9 \\
00 & 0 \\
7 & 0 \\
0 & 0\end{array}$} & Chemistry & 12 & & & & & & & $4^{*}$ \\
\hline & Physics & 8 & & & & & & & $4^{*}$ \\
\hline & Mathematics & 6 & & & & & & & $2^{*}$ \\
\hline & Earth Science & 3 & & & & & & & \\
\hline
\end{tabular}

NUTES:

Descriptions of Biology Courses

A. Principles of Biology. Characteristics of living organisms, cell theory, structural system of plants and animals, metabolism, maintenance of species (reproduction, heredity and development), maintenance of individual (health and disease)。

B. Plant and Animal Physiology and Anatomy. Norphology, study of tissues, functional activities of cells and tissues, reflexes and tropisms, functional units of systems, catalysis and enzymes.

C. Ecology and Conservation. Environment, soil, populations, relationships of species, distribution of communities. Field work should be an integral part of this course. This course could be coordinated with the work in Earth Sciences. 
D. Developmental Anatomy and Genetics. Growth and development, principles of heredity, evolution.

E. Preparation and Use of Biological Materials. This course should be conducted by one conversant with the problems of biology teachers. Consideration must be given to teaching techniques peculiar to biology. Preparation and proper use of demonstration and laboratory materials, teaching aids and methods should be emphasized.

* F Fifth Year. It is strongly recommended that a fifth year be added to the requirements for complete certification. The "year" could be taken during the four summers following completion of requirements for the bachelor's degree. There should be a minimum of mandated semester hours in biology, to permit more flexible selection of the courses which will be of most benefit to the teachers. "Cultural" courses in general science should be allowed (history of science, problems of atomic age, laboratory techniques in more than one science; et. al.). However, $25 \%$ of this year should be devoted to definitely biological topics, such as radiation biology (see Physics courses), microbiology, taxonomy, training in microtechnique. It is to be understood that more courses in biological sciences should be encouraged as electives.

Description of Chemistry Courses

Principles of inorganic chemistry, principles of organic chemistry, particularly as it applies to living things. Laboratory work should be included. *Biochemistry in the fifth year。

\section{Description of Physics Courses}

Introductory College Physics--mechanics, sound, heat, magnetism and electricity, light, selected topics in modern atomic and nuclear physics. $*_{A}$ complete course in modern physics, preferably integrated with the course in radiation biology, should be undertaken in the fifth year.

Description of Mathematics Courses

Study of fundamental concepts as well as manipulative processes in order to enable the student to understand the application of mathematics. Included should be the principles of algebra, trigonometry, analytic geometry. $*_{A}$ course in statistics is recommended for the fifth year. 
Description of Earth Science Course

Introduction to physical and historical geology, principles of meteorology.

General Considerations

The framework for develloping the above courses will vary from institution to institution. Certain alternate combinations could well be accepted, as long as the intent is accomplished. The title given to the course is merely a descriptive one. 
Science Background for the Teacher of General Science

This brief sketch is a synthesis of ideas concerning the science which the prospective specialist in the teaching of general science might take. It is based on the following assumptions:

1. This is a major in the teaching of general science.

2. The teacher of general science should have a broad background in the field, plus a specialty in one or more fields of science.

3. Courses prescribed for the general science teacher should be partly in terms of typical existing courses, partly in terms of courses specially structured for the prospective teacher.

4. Some requirements for general science teachers should be stated in terms of concepts and competence areas.

5. Based on a 4-year program of 120 semester hours, (nearly) half of the work should be in science. A five-year program is recommended, with much of the additional year's work in science.

Semester Hours

3-4 3 Botany including laboratory 3-4 $\}$ Basic Biol. Sci. \{Zoology including laboratory $\left.\begin{array}{c}2-3 \\ 2-3 \\ 3-4\end{array}\right\} \begin{gathered}\text { Special Areas of } \\ \text { Biol. Sci. }\end{gathered}$

8-10 Basic Chem. 8-10 Basic Physics

$2-3$

4-5 Special Areas 2-3 of Phys. Sci. ${ }^{*}$ Relations of living things to each other and to their physical environment

*Heredity, evolution, genetics Human physiology, anatomy, personal and public health Chemistry including laboratory Physics including laboratory * Nature of matter, energy of the atom Science of the earth, the air $\{$ (weather) and the sky Instrumentation, with special emphasis on electricity and electronics 
Semester Hours (cont.) Area (cont.)

$$
3-4
$$

$12-20$

$\left.\begin{array}{c}2-3 \\ 6-8\end{array}\right\}$

60
Techniques in the teaching of science

Upper division courses concentrated either in physical science or biological science (may be a "major field")

History and philosophy of science $\{$ (near end of program--preferably in fifth year)

Mathematics

Minimum total

* In some cases, these areas will be included in the introductory treatments immediately above starred items. 


\section{Supplementary Note}

The Recommendations in Report No. 4 are:

1. A policy of certification in closely related subjects within the broad area of science and mathematics should be established and put into practice。

2. Approximately one-half of the prospective teacher's four-year program should be devoted to courses in science.

3. Certification to teach general science at the 7 th, 8th, and 9th grade level should be granted on the basis of a broad preparation including college courses in all the subjects concerned in general science.

4. Colleges and certification authorities should work toward a five-year program for the preparation of high-school teachers.

5. Curriculum improvements in the small high schools should go hand in hand with improvement in teacher preparation.

The Sub Committee - - -

Henry Syer, Boston University

S. Winston Cram, Kansas State Teachers College

Fred Dutton, Michigan State University

Harold Wise, University of Nebraska

Bro. G. Nicholas, La Salle College

Robert Stollberg, San Francisco State College

Alfred B. Garrett, Chairman, The Ohio State University

Wayne Taylor, University of Texas 


\section{BIBLIOGRAPHY}

AAAS Cooperative Committee on Teaching of Science and Mathematics. "Recommendations for the Preparation of High School. Teachers of Science and Wathematics." Mimeographed report in progress, n.d.

Allerton House Conference on Education. Report on the Teaching of Science in Illinois. Carbondele, IIIo: Southern Illinois University, 1957.

Amendments to the Regulations of the Commissioner of RduCation, Article XV, Teachers Certificates. Albany, N. Y.: State Education Department, $n_{0} d_{0}$

Barnard, J. Darrell. Teaching High School Science. Washington, D.C.: National Uducation Association, 1956.

Earzun, Jacques. Teacher in America. Garden City, N.Y.: Doubleday \& Co., 1945.

Biennial Report of the Superintendent of Public Instruction of Wontana. Helona, Mont.: State lepartment of Public Instruction, 1956.

Board of Education of the City of New York. Science on the Horizon: Science Institute for the Formulation of Guide Lines for a Sequential $k-12$ Science Program. ivew York, 1959.

Ereukelman, John, and Ted F. Andrews. Offerings and Enroljments in the secondary school sciences in Kansas in 1954-1955. Limporia, Kan.: Kansas State Teachers College, 1956.

Brown, Kenneth $\mathrm{E}$, and Rllsworth S. Obourn. Qualifications and Teaching Loads of Mathematics and Science Teachers in Naryland, New Jersey, and Virginia. Washington, D.C.: Government Printing office, 1959.

Burnett, Will. Teaching science in the Secondary School. New York: Rinehart \& Co., 1957. 
Certification of Alabama Teachers. Montgomery, Ala.: State of Alabama, Department of Education, 1953.

Certification of Teachers and School Administrators in Nontana. Helena, Nont.: Superintendent of Public Instruction, 1959.

Certification Regulations. Cheyenne, Wyo.: State of wyoming, State Department of Education, 1956.

Gertification Regulations for l'eachers and qualifications for Administrators and Supervisors. Richnond, Va.: State Department of Education, 1955.

Certification of Teachers and Administrators. Olympia, Wash.: State Board of Education, 1956.

Conant, James B. The American High School loday. New York: vicGraw-Hili; 1959.

Curriculum Science Course of Study for Wontana, Tentative Physics Uutline. Helena, ilont.: Department of Public Instruction, 1959.

Fitzpatrick, Lo P. "The Scientific lianpower Problem and the Program of Teachers" College, Columbia University," Science Education, XIII, No. 2 (Warch, 1957), 140-145.

Hand, Harold Co. "Black Horses Bat More Than White Horses," American Association of University Professors' BulleEIn, KLIII, No. 2 (June, 1957), 200-79.

Harvard Committee. General Education in a Free Society. Cambridge, Mass.: Harvard University Press, 1952.

Illinois state Teacher Certification Board. Circular, Series A, No. 100. Springfield, I1l.: Superintendent of Public Instruction, 1956.

Johnson, Maxine C. "State and Local Taxes in Miontana," Montana Business Review, XI, No. 4 (April, 1959), 3-11.

Johnson, Philip G. The Teaching of Science in Public High Schools. Washington, D.Co: Government Printing office, 1950.

Killian, James R., Jr. "Lducation for the Age of Science," NEA Journal, XIIX, No. 2 (February, 1960), 10-l3. 
Koelsche, Charles L. The Academic and Teaching Backgrounds of Secondary Science Teachers in the State of Ohio. Toledo, Ohio: Research Foundation, University of Toledo, 1958.

Laurs and Regulations Governing the Certification of Teachers, Administrators, Supervisors, and School Employees in Fupil Personnel Service. Columbus, Ohio: State Department of Lducation, 1955.

Lindahl, Dean M. "A. Status Study of Chemistry in Montana Fublic High Schools." Unpublished Master of Arts thesis, ivontana State University, 1957.

Louisiana Standards for State Certification of School perSonnel. Baton Kouge, La.: State Department of Education of Louisiana, 1956.

Waster of Arts in Teaching. New Haven, Conn.: Yale University Graduate School, 1956-57.

Wathematics and Science Teaching and Pacilities. Washington, D.C.: National Education Association, 1959.

Mead, Margaret, and Rhoda Metraux. "Image of the Scientist among High-School Students," Science, CXXVI, No. 3270 (August 30, 1957), 384-390.

Miontana Almanac: 1959-60 Hdition. Missoula, Mont.: liontana State University, $195 \%$

Montana Sducational Directory, 1958-59. Helena, Hont.: State Department of Public Instruction, n。d.

New Developments in High School Science T'eaching. Washington, Doc.: National Science Teachers Association, 1960.

Nietz, John A. More Students Taking science and Wathematics, "School Science and irathematics, October, 1957, pp. $512-140$

1959-60 Guidebook. Wissoula, Wont.: Montana State University, 1959 .

Obourn, Ellsworth S. Analysis of Research in the Teaching of' Science, July 1955-July 1956。 Washington, D.C.: Government Printing Office, $195 \%$ 
"The Role of the Professional Science Educator in the Present Manpower Shortage," Science Education, XIII, No. 2 (March, 1957), 133-39.

Parkinson, C. Northcote. "Can Democracy Survive?" Saturday Evening Post, CCXxxII, No. 32 (February 6, 1.960), $38 \mathrm{ff}$.

PeILa, Milton 0 . "The Nature of the Academic Preparation in Science of Viisconsin liigh School Teachers of Fhysics, Chemistry, Biology, and General Science," Science Education, XIII (Narch, 1958), 106-37。

Fhysical Ścience Study Committee. Fhysics: Freliminary Edition. Cambridge, ivass., 1958。

"Pick of the Paperbacks," Saturday heview, XLIII, No. 7 (February 13,1960$), 30-31$.

Public Schools of Montana. Nashville, lenn。: Division of Surveys and Field Services, George Peabody College for Teachers, 1958 .

"Regulations for the Certification of Secondary School Teachers, "Concord, H.i.: State Board of Education, 1948. (ivimeographed.)

Rickover, iyman G。 Education and Freedom. NIew York: E. F。 Dutton \& Co., $19 \overline{59}$.

- "The world of the Uneducated," Saturday Evening Post, CCXXXII, No. 22 (November 28, 1959), $19 \mathrm{f}$.

School Laws of the State of wontana. Helena, mont.: State Department of Public Instruction, 1957.

Scott, C. Winfield. Meglected Issues in the Science Subjects Controversy, "American Association of University Prof'essors' Bulletin, XLIII, No. 4 (December, 1957), 581-712。

Sears, Paul B. "A Science Curriculum for Teacher Education," College and University, XII, No. 4 (November 15, 1959), 1-4。

Shaler, Nathaniel S. "Natural-History Education," The Addresses and Journal of Proceedings of the National Education Association, Session of the Year 1872 , at Boston, Massachusetts. The Association, pp。 232-59. 
Sletten, Vernon. "Some Aspects of Montana School District Reorganization and Examples." Unpublished paper, Montana State University, 1959.

Spencer, Herbert. Education. Akron, Ohio: Werner Co., 1860 .

Stanley, Nilliam 0., Harry S. Broudy, and R. Will Burnett (eds.). Improving Science Programs in Illinois Schools. Urbana, Ill.: University of Illinois, 1958.

State Department of Education Standards for Certificating Teachers in Secondary Schools. Nadison, Wis.: State Department of Public Instruction, 1950。

"A Study of Nontana Curricular Offerings Related to Distance Factors," Research Record, V, No. 3-4 (January, 1959), 1-1.2.

A Study of Ravalli County Public Schools. Missoula, Miont.: Bureau of Lducational Research and Services, Montana State University, $195 \%$.

Surmary of Teacher Education and Certification Standards. Harrisbure, Pa.: Department of public Instruction, n.d.

Teaching in North Carolina. Raleigh, N.C.: State Superintendent of Public Instruction, 1956.

Tennessee Regulations for Certification of Teachers. Nashville, Tenn.: State Department of Public Instruction, 1955.

Texas Curriculum Studies: Report of the Commission on Science. Austin, Tex.: Texas Education Agency, 1959.

U.S. Department of Health, Education, and Welfare. Mathematics and Science Education in U.S. Public Schools. Washington, D.C.: Government Printing Office, 1958。

- Offerings and Enrollments in Science and Mathematics in Public High Schools: 1956. Washington, D.C.: Government Printing Office, 1957.

Watson, Fletcher, Paul Brandwein, and Sidney Rosen (eds.). Critical Years Ahead in Science Teaching. Cambridge, Mass。: Harvard University, I953. 
"We Are Less Educated Than 50 Years Ago," U.S. News and World Report, XLI, No. 22 (November 30,1956 ), $68 \mathrm{ff}$ 。

Whitehead, Alfred North. The Aims of Education. New York: New American Library, 1956。

- Science and the Modern World. Hew York: New American Library, 1948. 


\section{AUTOBIOGRAPHY}

I, James Warren Gebhart, was born in Germantown, Ohio, on January 1, 1903. I received my secondary education there and at nearby Miamisburg High School, from which I graduated in 1920. I enrolled at Heidelberg University, now Heidelberg College, and in June, 1924, graduated with a Bachelor of Science degree with a major in chemistry. The following two years I spent at Waterville, Ohio, as high school principal and science teacher, and during this time began graduate work at Toledo University. I served as principal and science teacher at Germantown High School for " the next two years, attended the University of Wisconsin during two summers, and changed my major field of graduate study to biology. I spent one year. in industry and then returned to teaching, this time in Euclid, Ohio, where I remained except for two brief intervals until 1955, teaching chemistry, biology, and other science courses, and finally serving as chairman of the high school science department。

During these years I took graduate work at Western Reserve University and The Ohio State University, which granted my waster of Science degree in zoology in 1936. I also served one year (1937) as Fish Management Agent for 
the State of Ohio, and one year (1945) as Educational Assistant in Conservation Education for the state of Maryland. I filled various part-time teaching positions during this time--for the Extension Department of Kent State University, for Western Reserve University, the Cleveland Museum of Natural History, and finally on the sumner staff of Montana State University, whose permanent staff I joined in september, 1955, and where I am now an associate professor in the School of Education.

In addition to regular teaching duties, I have directed the summer Conservation Workshop for seven years, and last summer organized and directed a National Science Foundation Institute for high school teachers of science and mathematics. I am an active member of various scientific and professional organizations allied with conserva-tion, science, and science education. 